\title{
Internal quality management and organisational values in higher education : conceptions and perceptions of teaching staff
}

Citation for published version (APA):

Kleijnen, J. C. B. M. (2012). Internal quality management and organisational values in higher education : conceptions and perceptions of teaching staff. [Doctoral Thesis, Maastricht University]. Datawyse / Universitaire Pers Maastricht. https://doi.org/10.26481/dis.20120321jk

Document status and date:

Published: 01/01/2012

DOI:

10.26481/dis.20120321jk

Document Version:

Publisher's PDF, also known as Version of record

Please check the document version of this publication:

- A submitted manuscript is the version of the article upon submission and before peer-review. There can be important differences between the submitted version and the official published version of record.

People interested in the research are advised to contact the author for the final version of the publication, or visit the DOI to the publisher's website.

- The final author version and the galley proof are versions of the publication after peer review.

- The final published version features the final layout of the paper including the volume, issue and page numbers.

Link to publication

\footnotetext{
General rights rights.

- You may freely distribute the URL identifying the publication in the public portal. please follow below link for the End User Agreement:

www.umlib.nl/taverne-license

Take down policy

If you believe that this document breaches copyright please contact us at:

repository@maastrichtuniversity.nl

providing details and we will investigate your claim.
}

Copyright and moral rights for the publications made accessible in the public portal are retained by the authors and/or other copyright owners and it is a condition of accessing publications that users recognise and abide by the legal requirements associated with these

- Users may download and print one copy of any publication from the public portal for the purpose of private study or research.

- You may not further distribute the material or use it for any profit-making activity or commercial gain

If the publication is distributed under the terms of Article 25fa of the Dutch Copyright Act, indicated by the "Taverne" license above, 
Internal quality management and organisational values in higher education

Conceptions and perceptions of teaching staff 
This research was carried out at

Maastricht University Leading Learning!

In the school of Health Professions Education

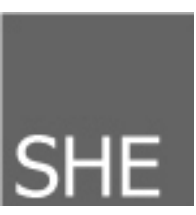

The printing of this thesis was financed by

\section{Zuyd}

Hogeschool

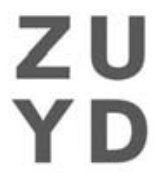

Omslagfoto:

Zuyd Hogeschool te Heerlen: brise-soleil boven de entree. Het gebouw van Zuyd Hogeschool in Heerlen werd opgeleverd in 1998 en is het resultaat van aandachtige analyse van de eisen van het onderwijs, creatief ontwerp en zorgvuldige planning en uitvoering. Het ontstond in intensieve samenwerking tussen de hogeschool, de architect, het projectbureau en de uitvoerders. Binnen de hogeschool was Math van Es (1948-2006) de inspirerende, onvermoeibare en blijvende coördinator van dit proces: een toonbeeld van kwaliteit in ontwikkeling. Foto: Maril Donders

(C) Jan Kleijnen, Maastricht 2012

Production: Datawyse | Universitaire Pers Maastricht

ISBN 9789461591265 


\title{
Internal quality management and organisational values in higher education
}

\section{Conceptions and perceptions of teaching staff}

\author{
PROEFSCHRIFT \\ ter verkrijging van de graad van doctor \\ aan de Universiteit Maastricht, \\ op gezag van de Rector Magnificus, \\ Prof. mr. G.P.M.F. Mols, \\ volgens het besluit van het College van Decanen, \\ in het openbaar te verdedigen \\ op woensdag 21 maart 2012 om 14.00 uur \\ door \\ Joannes Chrysostomus Bernardus Marie Kleijnen
}

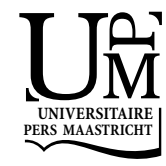




\section{PROMOTORES}

Prof. dr. J.F.M.J. van Hout, Universiteit van Amsterdam

Prof. dr. D.H.J.M. Dolmans

\section{CO-PROMOTOR}

Dr. J.M.H.M. Willems, Hogeschool Zuyd

\section{BEOORDELINGSCOMMISSIE}

Prof. dr. J.J.G. van Merriënboer (voorzitter)

Dr. H.J.M. van Berkel

Prof. dr. W.H. Gijselaers

Prof. dr. R.L. Martens, Open Universiteit Heerlen

Dr. H.A.P. Wolfhagen 
Voor Maril,

omdat zij is, wie zij is 



\section{Table of Contents}

Chapter $1 \quad$ Background of the research 9

Chapter 2 Theory, research questions and research design 23

Chapter 3 Organisational values in higher education: perceptions and 43 preferences of staff

Quality in Higher Education, 15(3), 233-249, 2009

Chapter 4 Teachers' conceptions of quality and organisational values in higher education: compliance or enhancement?

Accepted by Assessment \& Evaluation in Higher Education, http://dx.doi.org/10.1080/02602938.2011.611590, 2011

Chapter 5 Does internal quality management contribute to more control or to improvement of higher education? A survey on faculty's perceptions

Quality Assurance in Education, 19(2), 141-155, 2011

Chapter 6 Effective quality management requires a systematic approach and a culture of flexibility and open communication.

A qualitative study on conceptions, perceptions and values of academic staff in higher education

Submitted

Chapter 7 Conclusions and general discussion

Summary

Samenvatting

Dankwoord

Curriculum vitae

SHE Dissertation Series 

CHAPTER 1

Background of the research 
CHAPTER 1 


\section{Introduction}

In the Netherlands, accredited programmes leading to a vocational bachelor's and/or master's degree are offered by universities of applied sciences (UAS). For hundreds of thousands of students this is the final stage of their full-time education and the gateway to society. Since it is of the utmost importance that graduates should enter the labour market equipped with appropriate knowledge, skills and attitudes, the programmes and the facilities of UAS merit considerable effort and investment from government, organisations and individuals. It is therefore not surprising that the quality and costs of UAS are under constant scrutiny from the authorities and the public. Recently, more particularly in 2010 and 2011, the quality of UAS has come under severe criticism. Although many UAS departments work very hard to deliver high quality programmes and have an internal quality management system in place, strong doubts have been expressed about the general effectiveness of internal quality management in UAS. The aim of this thesis was to investigate the effectiveness of internal quality management within UAS departments from the perspective of the teaching staff. There is still little empirical evidence on this subject and the subject has not yet been researched in the context of Dutch higher education.

This first chapter describes the development of UAS in the Netherlands during the past thirty years, the role of public inspection and external quality assurance and developments in internal quality management in higher vocational education. Also it defines the subject of the thesis and the preliminary research questions, and it concludes with an overview of this thesis.

\section{Higher vocational education in the Netherlands}

The Netherlands has a binary system of higher education with traditional universities focusing on research and scientific education, and universities of applied sciences (UAS) focusing on vocational education and, since 2000, on applied research as well. Up till 1986, the scale of higher vocational education in the Netherlands was relatively modest. In 1983, there were 375 institutions with one or more departments of higher vocational education (Van Bemmel, 2006), many of which also offered secondary vocational education and training. From 1968 until 1986 higher vocational education was regulated by the Law on secondary education (WVO, 1963), and by detailed legislation and regulations from the education ministry. Although the government's influence on the educational process was limited, its influence on the institutes was quite strong as it provided funding for staff, facilities and other costs and it controlled the examinations. National examination requirements were in place for many programmes such as those of engineering colleges, 
teacher training colleges and health professions education, and some examinations were organised nationally, such as the qualifying examination for teachers in secondary vocational education. The Inspectorate of Education supervised higher vocational education until the 1970s, mostly by monitoring and evaluating the implementation and effectuation of government regulations. From the mid-seventies, the Inspectorate was increasingly involved in the improvement of education (Onderwijsraad, 1999, pp. 6-7). Inspectors were well informed about the internal and external situation of schools and about current developments. They engaged in discussions with school management and gave advice, combining a supervisory and an advisory role. Moreover, the Inspectorate had close ties with the Ministry of Education (Elte \& Scholtes, 2001, p. 53). School directors expected the Inspectorate to be knowledgeable about regulations and trends, developments and decision-making within the Ministry and to offer guidance to schools and be their advocates.

In the early 1980s, however, things began to change fundamentally. The number of students in higher education had risen from 300,000 in 1975 to 385,000 in 1985 , a rise from 187,500 to 205,000 in higher vocational education and from 130,000 to 180,000 in the traditional universities (Ministerie van Onderwijs, Cultuur \& Wetenschappen 2009). According to the report 'Quality of Education' (Ministerie van Onderwijs en Wetenschappen, 1981), the existing regulations for monitoring and control, particularly by the Inspectorate, were no longer adequate: "they are not sufficiently flexible; standard-setting is limited to education itself, with a lack of involvement of other people and agencies; there is no systematic quality inspection" (Frissen, 1985, p. 9). In 1983, the Ministry took measures to strengthen higher vocational education by increasing the size of institutions, dividing tasks between institutions and promoting concentration of schools (Schaalvergroting, Taakverdeling en Concentratie). This was expected to reduce the costs of higher vocational education and enable it to absorb the growing number of applicants (Ministerie van Onderwijs en Wetenschappen, 1983). A new statutory framework was provided in the 1986 Law on higher vocational education (WHBO, 1986), which was replaced in 1992 by the Law on higher education and scientific research (WHW, 1992), covering all of higher education in the Netherlands: the UAS, the traditional universities and the Open University. These policies considerably increased the effectiveness of the intended strategy. In 2009/2010, a total of 634,000 students was enrolled in higher education, of which 403,000 (64\%) in higher vocational education (CBS, 2010). The Ministry of Education expects this trend to continue until 2025 (Ministerie van OCW, 2011, p. 6). As the number of students in higher vocational education increased, the span of control of the Ministry of Education decreased. Of the 375 institutions of higher vocational education in 1983, only 44 remained by 2006 (Van Bemmel, 2006), but these institutions are huge, providing a wide range of full- and part-time bachelor programmes and numerous brief refresher and retraining courses for adults in almost all domains and disciplines. Master programmes are 
also offered and units for applied research have been set up. Today's higher vocational education institutions are known as universities of applied sciences (UAS).

\section{Public policies and external quality management}

The changes in the legal framework reflected a change in government policy. In 1985, under Minister Deetman, the HOAK paper on autonomy and quality in higher education was published emphasising that the institutions of higher education should have a greater say in the organisation and internal arrangements of higher education but that they should be accountable for the quality they delivered Ministerie van Onderwijs en Wetenschappen, 1985). This marks a turning point in the views on higher vocational education: "From regulation towards deregulation and from guidance on details to guidance on main issues" (Van Bemmel, 2006, p. 5). This change launched the development of a system of external quality assurance and accountability in higher education, a sector-based quality management system with a major role for the institutions. The Association of Universities in the Netherlands (VSNU) and the Netherlands Association of the Universities of Applied Sciences (HBO-Raad) - the employers' associations in higher education - convinced the Minister and the parliament that they should be in charge of the quality assurance process. As of 1989, all UAS programmes within a certain sector, for example all programmes in mechanical engineering, were visited and reviewed every six years by review committees of the Netherlands Association of UAS. The departments prepared for the visits by writing a self-evaluation report and the visitations resulted in reports on the quality of individual teaching programmes as well as the overall quality within each discipline. Gradually, the Netherlands Association of UAS developed a framework for quality assessment and comparison of programmes (HBO-Raad, 1999). This sector-based system of visitations and review remained in use until 2003.

The Inspectorate of Education was in charge of the monitoring of this process, but in the early 1990s, this task had become rather vague and it looked as if their role was played out. "The inspectorate was completely lost for some years."(F. Mertens, 2008, p. 5). Some years later, however, the (meta-)task of monitoring the visitations and reviews started to play a major role in the implementation of urgent recommendations and improvements. A few months after the reports of the review committees were published, the Inspectorate released a list of teaching departments with satisfactory performance as well as a list of departments with minor and major shortcomings (HBO-Raad, 1995). In this way the Inspectorate showed the departments green, yellow and red cards. Severe shortcomings were discussed with the Boards of Governors. In exceptional cases this could be reported to the Minister and lead to a ministerial warning (Article 6.7 of the higher education law (WHW)). 
The Inspectorate was also responsible for monitoring the progress of plans for improvement (Inspectie van het Onderwijs, 1999), which regularly resulted in urgent or binding recommendations by the Inspectorate. After investigating the first rounds of visitations and reviews, the Netherlands' Court of Audit (Algemene Rekenkamer) concluded "that all the recommendations concerning curriculum development have resulted in concrete measures after a period of four years on average" and to "a less immediately noticeable cultural change within departments, which are integrating quality considerations into their regular operations" (Jeliazkova and Westerheijden, 2000, p. 38).

Increases in public spending, due to the tremendous rise in the number of students, led to a desire for more public control and greater efficiency in terms of higher percentages of students graduating within the allocated time and a higher quality of education. In 1995 and 1996, the then Minister of Education, Ritzen, allocated funding for special projects to improve the quality of education by enhancing the 'quality and doability' of teaching programmes (Kwaliteit en studeerbaarheid: Ministerie van Onderwijs, Cultuur \& Wetenschappen, 1995 and 1996). Within the institutions and teaching departments this resulted in many projects aimed at enhancing professional competence, at stimulating students to become active learners and at developing custom-built learning tracks and assessment aimed at promoting student learning. At the end of the project period in 1999, the Inspectorate concluded that the efforts had been worthwhile but that the success rate had not improved: programmes had not been shortened and too many students did not graduate within the designated time (Inspectie van het Onderwijs, 2003, p. 49).

Early in 2000 , there were increased calls from society and politics for more accountability, and the external, sector-based quality management by the employers' associations in higher education came under increasing attack from government, parliament, student unions and the media. The Committee for the Accreditation of Higher Education, installed by the minister to review the system, concluded that external visitations and reviews should result in explicit, transparent and public evaluations and should be conducted by an independent body with no direct involvement of the employers' organisations and the government and with broad support in society. Accreditation by such a body was to be mandatory with clear consequences for institutes that were not awarded accreditation, such as withdrawal of funding and of the right to issue certificates (Commissie Accreditatie Hoger Onderwijs, 2001, p. 12). A modification of the law on higher education and scientific research (WHW) in 2003 introduced a system of accreditation at the level of teaching programmes as well as a special accreditation body: the Accreditation Organisation of the Netherlands and Flanders (NVAO), replacing the previous sector-based quality system with a system primarily emphasising public external accountability. Positive evaluation by the NVAO results in statutory accreditation of a teaching programme for a period of six years, and negative evaluation results in 
withdrawal of the right to award certificates and degrees and the loss of public funding. This system of accreditation was in use for both UAS and traditional universities in the Netherlands (and Flanders) between 2003 and 2011. In a mid-term review of the system, the Inspectorate of Education concluded that the system had given a positive impetus to the development of quality management in the majority of teaching departments (Inspectie van het Onderwijs, 2006). However, comparison between departments was difficult and the system was twice as expensive as the previous one. The institutes saw an increase in their annual external costs for the services of assessment agencies and the NVAO from $€ 4.8$ million for the previous system to $€ 10$ million for the national accreditation system, and this did not include the internal costs to the institutions and departments for internal preparation for the accreditation and for internal quality management activities (Inspectie van het Onderwijs, 2005).

Since another system change in 2011 , institutes instead of extensive quality assessments at the level of departments, can choose for quality assessment at the institutional level, encompassing a review by the NVAO of the institute's internal vision and policies on quality and of the internal quality assurance system, the availability of information on quality, output and results of departments and the organisation of the institute. If the evaluation of the institute is favourable, individual departments only have to take part in a limited assessment procedure focusing on the learning objectives, the teaching-learning environment (programme, quality of staff and specific services and facilities), the assessment system and the learning outcomes. The aim of the new quality assessment is that a "proper balance is achieved between assessing programmes on the one hand and quality improvement on the other" (NVAO, 2010a, p. 6). Although the principle of accreditation by the NVAO has remained unaltered, the new system states that NVAO decides to accredit a programme, not to accredit a programme or to allow a period during which improvements can be made (NVAO, 2010a, p. 22). This remedial period is a new feature of the system of accreditation.

\section{Internal quality management}

Endeavours to ensure and improve the quality of higher education date back to long before the formal introduction of external quality management systems. In the early stages, however, the main focus was on professional skills and craftsmanship and on the different disciplines or professional groups within teaching departments (Van Hout, 1986, Van Kemenade, 2006). More general quality management activities were developed in the 1980s, including an institutional strategy, plans for curriculum design and for measuring study load, analyses of strengths and weaknesses of the learning environment, methods of assessment and evaluation of quality and 
analysis of the professional working field (Heijnen and Joostens, 1990), but these activities were not yet combined into a structured quality system (Van Hout, 2006). At this stage of quality endeavours, the national developments described in the preceding paragraphs had a strong impact on the institutes. Within the teaching departments of the UAS, the first external visitations and reviews around 1990 stimulated a focus on internal quality assessment, surveys and evaluations, but it still took several years before formal quality assessments and surveys came to be generally accepted as valid methods of quality evaluation.

Within the newly created large multisectoral institutes that had remained after various mergers the Boards of Governors had to demonstrate their added value (Hulshof, Van Hout and Prins, 1990). They seized the opportunity of the Quality \& Doability programme launched by the ministry (1996 - 1999) to generate more proactive quality plans. The project funding was used to shift attention from the expost measurement of quality to the ex-ante processes of design and implementation of learning programmes, of guidance and supervision of student learning and of testing and assessment. Policies and action plans of the universities and the departments were the centre of attention, and quality assurance manuals were produced. Many institutions and teaching departments proceeded to identify and describe structures, tasks and responsibilities. Procedures were worked out in detail. Targets were specified and formulated using the SMART model (specific, measurable, acceptable, realistic and time-limited). Human and material resources and conditional processes were specified and included in the manuals, and the results were measured and assessed. Plans and their implementation were to be monitored and the monitoring should lead to adjustments. The cycle of improvement, often modelled after the Deming cycle (PDCA: plan, do, check, act), was documented and known to the staff member entrusted with quality management, to some project workers and to most directors and managers of departments. But the quality process was not well known to the majority of teaching staff. It would take further efforts to gain broad internal acceptance and support. Quality management appeared to be not only a matter of planning, designing methods and applying techniques, but it was also important to ensure that teaching staff and other personnel actively embraced the quality movement.

After 2000, some UAS introduced planning and control cycles (P\&C), aimed at aligning central policies with the plans of the departments. In some UAS an audit team was set up to support the $P \& C$ cycle, to ensure the availability of the necessary documents for planning, reporting and accounting and to facilitate the regular periodic consultations between the Board of Governors and the department directors (for example, Hogeschool Zuyd, 2002). Consistency of policies was promoted by creating networks across organisational borders.

The impact of all these internal quality management activities was not clear. In fact, it also is not really known what impact external quality management had, other 
than that it stimulated the rise of internal quality management. The disappearance of programmes that did not meet the accreditation standards was the most noticeable result of the first accreditation round, but this concerned less than $1 \%$ of the existing programmes (NVAO, 2010b, p. 12). Another result was that "in the past few years quite a few teaching programmes that had been offered until then were not submitted for accreditation" (NVAO, 2010c, p. 21). Secondly, the assessment reports of the NVAO (website) show that there are some excellent departments where teachers and students are proud of their programmes. The results and the levels achieved at graduation are good, and there is a good relationship between students and teachers. Students and the professional working field know what to expect and they are satisfied. Teaching staff form a coherent team. The curriculum is well designed, in line with the requirements of professional practice and well delivered. There is a general feeling that improvement is important. In some of these departments proceedings are formalised and well documented. Some departments, however, notably in the creative arts, have good or excellent teaching programmes but are more loosely organised, with less formal regulation and documentation. In these programmes, traditional skills are often highly valued and quality of education is a permanent concern. Finally, despite efforts in the area of quality assurance, many accredited UAS bachelor programmes (NVAO 2009, p.15) remain vulnerable to quality-related problems. While the accreditation process reveals the quality of programmes and departments, it nevertheless remains unclear whether this process and the related formal procedures of internal quality management are having any real positive effect.

The most evident effects of internal quality management are that the main quality processes have been formalised within many departments and that quality management is now on the agenda (Van Hout, 2006). Within all UAS, attention is paid to institutional strategy and policy and to the interaction between institutional policy and the teaching departments. In almost all teaching departments, overarching quality issues are a topic of discussion: the quality of the curricula, the differentiation of the educational programme in terms of level and subject matter, the competency level of graduates, the relevance of external contacts with employers and professional practice and of internationalisation, and the flexibility and regular adaptation of the programmes. Awareness is growing that learning tracks could provide opportunities for crossing the borders between different educational programmes (Van Hout, 2006) and special programmes are designed for excellent students. Attention is given to the professionalisation of teachers in respect of their subjects and their educational expertise. Institutions offer refresher and retraining courses and special routes for high-potentials and stimulate participation in research programmes. Awareness is stimulated of the relevance of the physical and electronic learning environments and of the importance of efficiency, feasibility and affordability of programmes. However, awareness and formal attention do not 
guarantee real commitment and active participation in quality management, and in many departments the quality culture is rather weakly developed (Dittrich, 2010). In short, there is still a great deal of work to be done in the area of quality management (Van Hout, 2006; EUA, 2010).

\section{Research problem and preliminary research questions of this dissertation}

The primary goal of both internal and external quality management is to raise educational quality (Van Hout, 2006), but this goal is not achieved in all teaching departments despite the presence of a quality assurance system. In fact, there is criticism of the quality of educational programmes within the UAS, and there are doubts as to the effectiveness of internal and external quality management. Some critics argue that quality management merely increases bureaucracy, while others claim that it does result in continuous improvement. Some critics advocate for a stronger focus on basic theoretical knowledge and more skill training. At the same time there is a call for a more ambitious quality culture, reflecting a more active attitude of students and teachers towards learning and work, mutual cooperation and a desire to excel (Ministerie van Onderwijs, Cultuur en Wetenschappen, 2011). Overall, the effectiveness of internal quality management is a topic of debate, a debate that is, unfortunately, not informed by a great deal of empirical evidence.

The aim of this thesis is to investigate the effectiveness of internal quality management from the perspective of teaching staff. They are the professionals who develop the educational programmes, deliver them and supervise and assess the students. As Van Hout (2006, p. 224) claims, teaching staff are not just stakeholders that might be involved in quality management: "Teaching staff, being the carriers of education, should be seen as the instigators and primary actors and pillars of quality management". Teachers' perceptions of the effectiveness of internal quality management may depend on how they view quality. Do they pursue basic knowledge or a quality culture? Does quality mean that the educational programme has to meet certain basic standards or does it mean continuous improvement? This question could also be asked with regard to departments, but at departmental level it can only be answered if there is a shared view of quality, the objectives of education and the aims of the department, in other words the answer depends on the organisational values that are preferred within a specific department and the degree to which these values are integrated in day-to-day practice (Van Kemenade \& Van Schaik, 2006).

The effectiveness of quality management might also depend on how quality management is interpreted. When there is one shared vision and perspective with regard to quality management, it can be confined to straightforward evaluations 
and improvements, but when different starting points and different perspectives are accepted as legitimate, a more complex and more formalised system of quality management may be required with consultations and agreements and with clear rules and procedures. Such a system may have bureaucratic tendencies and may be regarded as cumbersome (Van Kemenade \& Van Schaik, 2006). In such cases "tension may arise between educational quality and the quality of quality management" (Van Hout, 2006, p.223).

This type of tension can be effectively reduced in organisations where there is a general consensus on goals, structures and responsibilities, in other words where there is support for the 'coordination mechanisms' that regulate and align the various processes (Mintzberg, 1983). UAS and traditional universities, however, "generally do not excel in organisational quality" (Van Hout, 2006, p. 223). Mintzberg (1983) describes five coordination mechanisms. All of them seem to be rather weak within education. However, he also identifies a sixth mechanism operating within each of these five mechanisms: 'ideology'. This is the system of views on the organisation, built around an inspiring mission but very loosely structured. According to Marx (1986), this 'ideology' mechanism refers to the concept of culture in sociology. The views are the values and standards that are alive within an organisation.

This thesis addresses the effectiveness of internal quality management within teaching departments of UAS from the perspective of the teaching staff. Firstly, it investigates teachers' preferred organisational values within the context of their teaching departments and which values teachers perceive to be current in their department. The second question focuses on teachers' conceptions of quality. Do teaching staff see quality as meeting basic requirements or as continuous improvement of education? Thirdly, this thesis deals with teachers' perceptions of quality management within their department. In the eyes of the teachers, do departments pay sufficient attention to the relevant aspects of quality and do they undertake enough quality management activities? The fourth question is: what are teachers' perceptions of the effectiveness of internal quality management? And the final question relates to whether an understanding of teachers' conceptions and perceptions can contribute to answering the question why quality management is more effective in some departments than in others?

\section{Overview of chapters}

In the next chapter, the literature on conceptions of quality, quality management and its effectiveness and organisational values are explored in depth. The research questions are stated and the research methods described. The third chapter addresses the organisational values that teaching staff consider desirable and the values that prevail within their teaching departments. Special attention will be paid 
to differences between flexibility-oriented and control-oriented organisational values and to differences between departments. The fourth chapter discusses the question of whether teachers favour a concept of quality as compliance with basic standards and accountability or whether they prefer a concept of enhancement and improvement of teaching and learning. It is also investigated how these notions relate to preferences for organisational values. The fifth chapter deals with quality management within departments and teachers' perceptions of its effectiveness. Here too attention is paid to the differences between departments and the relationship between the performance of quality management and its perceived effectiveness. The results of chapters 3 to 5 were obtained from a quantitative survey among 266 teachers of eighteen UAS departments. In chapter 6 , these findings are complemented and deepened by an analysis of qualitative interviews with eighteen senior staff members in total from six different departments, three with more and three with less effective quality management according to the results of the quantitative study. The chapter elucidates the relationships between organisational values and teachers' conceptions of quality and the implementation and effectiveness of quality management. Chapter 7 presents an overview of the main findings and conclusions from the preceding chapters and discusses their scientific and practical significance.

\section{References}

CBS, Centraal Bureau voor de Statistiek. (2010). Hoger onderwijs: ingeschrevenen naar studierichting en naar leeftijd [Higher education: enrolled students by programme and age]. Available at: http://statline.cbs.nl/StatWeb/publication/?VW=T\&DM=SLNL\&PA=70943ned\&LA=NL (accessed 21 March 2011).

Commissie Accreditatie Hoger Onderwijs. (2001). Prikkelen Presteren Profileren. Eindrapport. [Promoting, Performing, Profiling. Final Report]. Amsterdam: Van de Bunt.

Dittrich, K. (2010). Toespraak NVAO-voorzitter Karl Dittrich: Nationaal Onderwijs Congres, Eindhoven [Address of the NVAO chairman, Karl Dittrich: National Education Conference, Eindhoven]. Available at: http://www.nvao.net (accessed 5 July 2011).

Elte, R., \& Scholtes, E. (2001). Uit de luwte. Over strategische verandering in en rond de onderwijsinspectie 1990-2000 [Out of hiding. On strategic changes within and around the Inspectorate of Education 1990-2000]. Utrecht: Inspectie van het Onderwijs.

EUA. European University Association. (2010). Examining quality culture: part I - Quality assurance processes in higher education institutions. Brussels: EUA.

Frissen, P. (1985). De overheid en kwaliteitsbewaking in het hoger onderwijs [The government and quality assurance in higher education]. In H.J.M. van Berkel \& A.E. Bax (Eds.). Kwaliteit van hoger onderwijs. Bewaking en verbetering (pp. 8-15) [Quality of higher education. Monitoring and improvement (pp. 8-15)]. Amsterdam: Versluys.

HBO-Raad. (1995). Sectorale kwaliteitszorg in kort bestek [A brief overview of sector-based quality assurance]. Den Haag: HBO-Raad.

HBO-Raad. (1999). Het basisbeoordelingskader dat door de HBO-Raad wordt gebruikt voor het visitatiestelsel in het Hoger Beroepsonderwijs [The basic evaluation framework used by the HBO-Raad for the visitation system in Higher Vocational Education]. Den Haag: HBO-Raad. 
Heijnen, G.W.H., \& Joostens, T.H. (1990). Interne kwaliteitszorg: een doos van Pandora? [Internal quality assurance: a Pandora's box?]. In G.W.H. Heijnen, T.H. Joostens \& A.I. Vroeijenstijn. Kwaliteitszorg, waarborg voor kwaliteit in het hoger onderwijs (pp. 31-41) [Quality assurance, a guarantee for quality in higher education (pp. 31-41)]. Groningen: COWOG.

Hogeschool Zuyd. (2002). Jaarverslag 2001 [Annual report 2001]. Heerlen: Hogeschool Zuyd, internal report.

Hulshof, M.J.F, Van Hout, J.F.M.J,, \& Prins, J.B.A. (1990). Onderwijsvernieuwing in het HBO: een onderzoek naar de richting en aanpak van het vernieuwingsproces (Volume 22 van Beleidsgerichte studies hoger onderwijs en wetenschappelijk onderzoek) [Innovation of education in higher vocational education: research into direction and methods of innovation (Volume 22 of Policy studies in higher education and scientific research)]. Den Haag: Ministerie van Onderwijs en Wetenschappen.

Inspectie van het Onderwijs. (1999). Toetsingskader inspectie hoger onderwijs [Assessment framework of the inspectorate of higher education]. Breda: Inspectie van het Onderwijs.

Inspectie van het Onderwijs. (2003). Studeerbaarheid in het hoger onderwijs (Inspectierapport nr. 20038) [Doability in higher education (Report of the inspectorate nr. 2003-8)]. Utrecht: Inspectie van het onderwijs. .

Inspectie van het Onderwijs. (2005). Accreditatie: de kosten in kaart (Inspectierapport 2005-20) [Accreditation: mapping the costs (Report of the inspectorate nr. 2005-20)].Utrecht: Inspectie van het Onderwijs.

Inspectie van het Onderwijs. (2006). Accreditatie. De opleiding aan het werk. (Inspectierapport 2006-36) [Accreditation. education in action. (Report of the inspectorate $\mathrm{nr}$. 2006-36)]. Utrecht: Inspectie van het Onderwijs.

Jeliazkova, M., \& Westerheijden, D.F. (2000). Het zichtbare eindresultaat. Doorwerking van onderwijsvisitaties in hogeronderwijsinstellingen [The visible results. Effects of education visitations in institutions of higher education]. Den Haag: Algemene Rekenkamer.

Marx, E.C.H. (1986). Universitaire organisatie in ontwikkeling [Academic organisation under development]. In P. Frissen, P.M.Th. Van Hoewijk \& J.F.M.J. van Hout (Eds.) De universiteit: een adequate onderwijsorganisatie (pp.56- 80) [The university: an adequate education organisation (pp.56- 80)]. Utrecht: het Spectrum BV.

Mintzberg, H. (1983). Structure in fives: designing effective organizations ( $2^{\text {nd }}$ ed.). Englewood Cliffs, NJ, USA: Prentice Hall.

Mertens, F. (2008). Inspecteur-generaal van het onderwijs 1996 - 2001. Aantekeningen en fragmenten over de ontwikkeling van het toezicht op het onderwijs [Chief inspector of education $1996-2001$. Notes and fragments concerning the development of the monitoring of education]. Nijmegen: Hogeschool van Arnhem en Nijmegen.

Ministerie van Onderwijs en Wetenschappen. (1981). Nota kwaliteit van het onderwijs. [Paper on the quality of education]. 's Gravenhage: Ministerie van Onderwijs en Wetenschappen.

Ministerie van Onderwijs en Wetenschappen. (1983). Beleidsnota schaalvergroting, taakverdeling en concentratie. [Policy document on scaling up, division of tasks and concentration]. 's Gravenhage: Ministerie van Onderwijs en Wetenschappen.

Ministerie van Onderwijs en Wetenschappen. (1985). Hoger onderwijs: autonomie en kwaliteit. Een andere besturingswijze [Higher education: autonomy and quality. A different method of control]. 's Gravenhage: Ministerie van O\&W.

Ministerie van Onderwijs, Cultuur en Wetenschappen. (1995). Rapport van de stuurgroep kwaliteit en studeerbaarheid [Report of the steering group quality and doability]. Den Haag: Ministerie van OC\&W.

Ministerie Onderwijs, Cultuur en Wetenschappen. (1996). Wijziging van de Wet op het hoger onderwijs en wetenschappelijk onderzoek in verband met de bevordering van de kwaliteit en de studeerbaarheid van het onderwijs d.d. 8-3-1996 [Amendment of the Law on higher education and scientific research in relation to improvement of the quality and doability of education, dated 8-3-1996]. Den Haag: Ministerie van OC\&W. 
Ministerie van OC\&W. (2009). Kennis in Kaart 2009. Hoger Onderwijs en Onderzoek [Mapping knowledge 2009. Higher education and research]. Den Haag: Ministerie van OC\&W.

Ministerie van Onderwijs, Cultuur en Wetenschap. (2011). Kwaliteit in verscheidenheid. Strategische agenda hoger onderwijs, onderzoek en wetenschap [Quality in diversity. Strategic agenda for higher education, research and science]. Den Haag: Ministerie OCW.

NVAO. Dutch website available at: http://www.nvao.net (accessed 5 July 2011).

NVAO. English website available at: http://nvao.com (accessed 5 July 2011).

NVAO. (2009). Verbouwen en vernieuwen. Jaarverslag 2009 [Reconstruction and renovation. Annual report 2009]. Den Haag: NVAO.

NVAO. (2010a). Assessment frameworks for the higher education accreditation system. Den Haag: NVAO. Available

http://www.nvao.net/page/downloads/Assessment_frameworks_for_the_higher_education_accred itation_system_6_Dec_2010.pdf (accessed 21 March 2011).

NVAO. (2010b). Vijf jaar NVAO. Kwaliteit getoetst [Five years of NVAO. Quality assessed]. Den Haag: NVAO.

NVAO. (2010c). Steun en samenwerking. Jaarverslag 2010 [Support and cooperation. Annual report 2010]. Den Haag: NVAO.

Onderwijsraad. (1999). Deugdelijk toezicht. Advies over de nota Variëteit en Waarborg. Adviesnr. 990473/450 [Effective control. Advice on the memorandum on Variety and Guarantees. Advice Nr. 990473/450]. Den Haag: Onderwijsraad.

Van Bemmel, Ad. 2006. Hogescholen en hbo in historisch perspectief [UAS and higher vocational education, a historical perspective]. Den Haag: HBO-Raad. Available at: http://www.hboraad.nl/index.php?option=com_docman\&task=cat_view\&gid=42\&Itemid=5 (Sub: 'Geschiedenis Hogescholen'; accessed 21 March 2011)

Van Hout, J.F.M.J. (1986). De diversiteit in de cognitieve en sociale organisatie van wetenschapsgebieden en universitaire onderwijs [The diversity within the cognitive and social organisation of scientific fields and academic education]. In P. Frissen, P.M.Th. Van Hoewijk \& J.F.M.J. van Hout (Eds. .) De Universiteit: een adequate onderwijsorganisatie (pp.96-126) [The university: an adequate education organisation (pp.96-126)]. Utrecht: het Spectrum BV.

Van Hout, H. (2006) Kwaliteitszorg in het HO: nog veel werk aan de winkel [Quality assurance in higher education: much remains to be done]. In H. van Hout, G. ten Dam, M. Mirande, C. Terlouw \& J. Willems (Eds.), Vernieuwing in het hoger onderwijs. Onderwijskundig handboek (pp. 215-228) [Innovation in higher education. Education handbook (pp. 215-228)]. Assen: Van Gorcum.

Van Kemenade, E., \& van Schaik, M. (2006). Interne kwaliteitszorg, van ambacht naar visie [Internal quality assurance, from craft to vision]. In H. van Hout, G. ten Dam, M. Mirande, C. Terlouw \& J. Willems (Eds.), Vernieuwing in het hoger onderwijs. Onderwijskundig handboek (pag. 229-244) [Innovation in higher education. Education handbook (pp. 229-244)]. Assen: Van Gorcum. 
CHAPTER 2

Theory, research questions and research design 
CHAPTER 2 


\section{Introduction}

Most institutions and departments of higher education put much time and energy into internal quality management systems, initially mainly driven by considerations of accountability, but in recent years increasingly directed towards continuous improvement of educational quality (Sallis, 2002; Harvey \& Newton, 2007; EUA 2010). The huge debate on the effectiveness of internal quality management is dominated by two opposing viewpoints: some argue that quality management results in nothing more than extra administrative workload and others that quality management is a useful contribution to continuous improvement and transformation. There is not much empirical evidence to support either point of view, but judgments of the effectiveness of quality management are known to depend on the conceptions of quality held by different groups, including especially teaching staff (Gibson 1986; Newton, 2000). What are teachers' conceptions of quality of education? Do they see quality as compliance with minimal standards or as striving after improvement and transformation? The way quality management is organised within a department also has an influence on its effectiveness (Lewis \& Smith, 1994; Sallis, 2002). Is it only a matter for a few staff members with specific tasks or are all members of management and teaching staff involved in quality management? Besides, it is known that the effectiveness of internal quality management depends on the organisational culture and values. Implementing quality management should take account of the specific values that prevail within the organisation (Cameron \& Quinn, 1999; Kezar \& Eckel, 2002). Some organisations are characterised by an orientation towards flexibility oriented values and others towards control oriented values. The question to be answered therefore is: which organisational values do teaching staff prefer and which do they experience in the department and how does this relate to their conceptions of quality, the organisation of internal quality management and the effectiveness of quality management?

This chapter starts with a discussion of theories and empirical evidence on quality, internal quality management and its effectiveness, followed by a discussion of different organisational values in higher education and how they relate to the effectiveness of internal quality management. The chapter concludes with the research questions, a framework illustrating the relationships between the different concepts and a description of the research methods. 


\section{Theory}

\section{Quality in higher education}

Judgments of the quality of education and the effectiveness of quality management are strongly affected by the conceptions of those making the judgments, including teaching staff. How people conceive of the quality of higher education depends on their answers to the following questions: " . . . what is the purpose of a university? What are the right things for the university to do to achieve its purpose? What are the right ways of doing them?" And "how can we . . . do better towards achieving our purposes" (Houston, 2008, p. 68). Consequently, different groups with different backgrounds, values and interests tend to be divided in their answers to these questions. The general consensus among scholars seems to be that it is impossible to arrive at a universally accepted definition of quality (Gibson, 1986; Harvey \& Green, 1993; Lanarès, 2008). Quality can only be viewed 'in relation to' the interests and expectations of those involved: students, teachers, the professional working field, executive boards, faculty deans and directors. Furthermore, it depends on the type of involvement and the situation (Garvin, 1988). Quality is thus a "highly contested concept" (Tam, 2001, p. 47). It may be the subject of a power struggle (Tam, 2001; Barnett, 2003) or "a matter of negotiating between all parties concerned" (Vroeijenstijn, 1995, p. 14).

Harvey \& Green (1993) elaborated the idea of a wide range of views on quality from different angles, and their classification of concepts is widely used (EUA, 2006; Newton, 2007; Parri, 2006; Harvey \& Stensaker, 2008; Nicholson, 2011). Based on the tenets of the quality movement in the twentieth century, quality is described in seven different ways, the first three of which are product or result oriented: 1 ) Quality is an apodictic and universal entity, which is well-nigh impossible to define but has originality, uniqueness and invested efforts as its vital ingredients; 2) Quality is conforming to a set of minimum standards; 3) Quality is excellence, based on high standards that have to be exceeded (Harvey \& Green, 1993, p. 12); 4) Quality is perfection (zero defects). Here the production process is central and the concept embraces a philosophy of prevention rather than inspection; 5) Quality as fitness for purpose, depending on the specifications of teaching staff, or fitness for use, depending on the expectations of students and the professional field; 6) Quality is value for money: do students, the government, tax payers and the business community receive value for money and is their money spent wisely? 7) The last concept compares quality to transformation. This concept is rooted in the notions of fundamental change and innovation, of enhancement of students' knowledge, abilities and skills and of the empowerment of participants.

Are teachers aware of this variety of quality concepts? Despite the manifold definitions, many authors distinguish two broad categories, one focused on the 
accountability process, the other focused on improvement or transformation (Harvey \& Green, 1993; Sallis, 2002; Watty, 2006; EUA, 2006; Harvey \& Newton, 2007; Lomas, 2007; Findlow, 2008; Houston, 2008; Brundrett \& Rhodes, 2011). Harvey and Green (1993), describing the seven concepts of quality, also identify two conceptions or approaches of quality. The first one is based on absolutes: quality is selfevident or based on more or less absolute and generally accepted standards or thresholds, which " . . . have to be exceeded to obtain a quality rating" (Harvey \& Green, 1993, 10). These standards may be professional or academic, minimal or of a high level to attain excellence. The focus is on results and external accountability. The second conception "is relative to the processes that result in the desired outcomes" (Harvey \& Green, 1993, p. 10). The focus is not primarily on how objectives can be attained as effectively as possible but on whether transformation or improvement and qualitative change can be achieved. Sallis (2002) also distinguishes two types of conceptions of quality: procedural quality, with key descriptors relating to proving, approving and reporting of product and service standards, and transformational quality, focusing on the customer: improving rather than proving, and aspiring and striving after excellence, even when not yet meeting it (Sallis, 2002, pp. 14-15). A third example of the two distinct conceptions is presented in the final report of the Quality Culture Project of the European University Association (EUA, 2006), which investigated the quality culture in 134 European universities by means of discussions with various network representatives of these institutes. Starting from a list of nine quality definitions, project participants identified ample evidence of two quality approaches: a standards-based approach and an approach focused primarily on the processes of development, implementation and improvement. "Quality is an on-going exercise; it is not a state that is reached once and for all but one that needs to be pursued continuously" (EUA, 2006, 10).

\section{Research on conceptions of quality}

Apart from the EUA report, based on experts' opinions (EUA, 2006), there has not been a great deal of research into conceptions of the quality of teaching. Using an indirect approach, Cartwright (2007) conducted in-depth interviews with six academics about their perceptions of the national quality agenda of the Quality Assurance Agency in the UK. The interviewees described the agenda as a system "in which the language of quality has been high-jacked" and which is characterised by a "tick-box approach", "imposition of control by increasingly intrusive management, the emergence of a blame culture and being forced to jump through irrelevant hoops" (Cartwright, 2007, 296). Cartwright concluded: "All my interviewees believed in 'quality' and had personal and professional commitment to the idea that their students were entitled to a 'quality' academic experience" (Cartwright, 2007, 295). Nevertheless, this study did not clarify teachers' conceptions of quality. In interviews with twenty university lecturers about their perceptions of quality initia- 
tives of universities in the UK, Lomas (2007) found that the lecturers perceived the quality initiatives as relating to consumers' perspectives, as quality assurance and control, as concentrating on process rather than content, as striving for standardisation and as conformity instead of diversity. They expressed a preference for a 'hands-off' approach as regards their professionalism and for more time for research, reading scientific literature and preparing educational materials. A postal survey by Watty (2006) asked 231 academics from 39 Australian universities which of four of Harvey and Green's concepts (1993) ('fitness for purpose', 'value for money', 'excellence' and 'transformation') were currently being promoted in their departments and which they thought should be promoted. For the current situation, 'fitness for purpose' and 'value for money' received high ratings and the lowest rating was for 'transformation'. However, transformation scored highest among the concepts the respondents thought should be promoted. All these studies suggest that teaching staff have a preference for improvement and transformation, whereas in practice quality tends to be focused on compliance with standards. Empirical data are however scarce.

\section{Quality management and its effectiveness}

It is assumed that the judgment of teaching staff of the effectiveness of quality management depends not only on their conceptions of quality but also on the organisation and operation of internal quality management. The term internal quality management is used here with reference to all quality-related activities for which the initiative and responsibility lie with the institute (Vanhoof \& Van Petegem, 2007). Within teaching departments it comprises all activities and processes that are deliberately carried out to design, assure, assess and improve the quality of teaching and learning, including motivational human factors. Internal quality management also includes external focus, communication with external partners and insight into consumers' expectations (Westerheijden, 1999; Harvey and Newton, 2004).

In the twentieth century, quality management evolved in an additive process of overlapping stages (Garvin, 1988; Van der Bij, Broekhuis \& Gieskes, 2001; Brundrett \& Rhodes, 2011). The first stage is 'quality inspection' with a focus on products, defect tracking during and after the manufacturing process and statistical methods of measuring and specifying tolerance limits. The second stage focuses on 'quality engineering' or 'quality control' and concentrates on the design of products or services, based on a list of specifications and requirements to avoid or minimise defects. The third stage focuses on 'quality assurance' and working processes with more consideration of motivational aspects of work, such as communication, organisation and training, and input factors and material requirements. Industry and organisations are aware of the importance of customers' expectations and empha- 
sise the importance of documentation, standards and auditing. Total Quality Management (TQM) is mostly seen as the final phase of the quality management process. The purpose of TQM is to avoid a one-sided approach to quality management by ensuring that quality management is an integral part of the work and production process and not a separate entity for which management is responsible. TQM is based on research, facts and evidence (Grant, Mergen \& Widrick, 2004; Harvey \& Newton, 2007) and it pays systematic and comprehensive attention to all relevant aspects. Quality management now focuses on continuous improvement, using methodical proceedings rooted in the so-called Deming cycle (Plan, Do, Check, Act), and on involvement of all relevant organisational levels, from strategic management to grass roots teaching staff and other personnel. It implies changing mind-sets, organisational culture and external communication with consumers, suppliers and other external partners. Transparency and communication are essential to maintain external focus and internal participation. (Garvin, 1988, Vroeijensteijn, 1990; Lewis \& Smith, 1994; Sallis, 1996; Van der Bij, Broekhuis \& Gieskes, 2001; Wolfhagen et al., 2002; Wiklund et al., 2003; Sahney, Banwet \& Karunes, 2004; Newton, 2007; Brundrett \& Rhodes, 2011).

The aspects of education subjected to quality management are usually described as inputs or requirements, processes, and outputs or results (Owlia \& Aspinwall, 1989, Segers, 1993; Vroeijensteijn, 1995; Cave, Hanney, Henkel \& Kogan, 1997; Van Damme, 2004; Wiklund, Klefsjö, Dandvik Wiklund \& Edvardsson, 2003; Sahney, Banwet, \& Karunes, 2004; Becket \& Brookes, 2006). Inputs include financial, physical and human resources, such as staff quantity and quality, the competencies of enrolling students and facilities. Processes comprise technical and professional variables, such as the goals of teaching and learning, the design and delivery of programmes, the creation of an educational organisation, student guidance and assessment. Processes also comprise soft process or relational variables, such as trustworthiness of teaching staff, accessibility, friendliness or credible communication (Parasuraman, Berry \& Zeithaml, 1991; Rust \& Olivers, 1994). Output factors include pass/fail rates and competency levels of graduates but also indirect factors, such as career opportunities for alumni and impact on the labour market and society (Segers, 1993; Vroeijensteijn, 1995; Van Damme, 2004). In some way quality management has to take account of all these elements, for example like the European Foundation for Quality Management and its Dutch partner INK do by including steering processes, primary and supportive processes, results and evaluations of results and processes of improvement and innovation in their management models (INK, 2008). 
Research on quality management and its effectiveness

There is no general agreement on the wisdom of dedicating a significant amount of time and energy to internal quality management. Does this actually improve the quality of education? According to Zbaracki (1998) and Ahaus (2006) ardent advocates of quality management frequently resort to a rhetoric of success. Experiences with mounds of paperwork, however, often resulted in a growing belief that quality management stifles rather than boosts quality. They evoke frequent and emotional discussions and the aforementioned rhetoric of advocates spawns equally impassioned counter-rhetoric from opponents (Ahaus, 2006). Most professionals and researchers are well aware of the ambivalences of quality management (e.g. Brennan \& Schah, 2000; Newton, 2000 and 2002; Van Damme, 2004; Harvey \& Newton, 2004; Milliken \& Colohan, 2004; Van Hout, 2006; Watty, 2006), and research has moved beyond the question "whether quality assurance systems and procedures are developed and in existence" (Stensaker, 2007, 59). Initial (over)enthusiasm has faded and quality management has become a 'maturing field'. The emphasis in research has shifted to the impact of quality management on educational improvement. Nevertheless evidence-based quality management is still very much in its infancy (Ahaus, 2006; Stensaker, 2007).

Many negative effects have been reported, mostly based on interviews or discussion groups and case studies but sometimes also from small surveys among teaching staff. Newton (2000 and 2002) conducted extensive qualitative research, including focus group interviews with front-line academics, revealing perceptions of increasing bureaucracy, a rise of standardisation and control and a shift of power from the departments to central level, "linked to a withdrawal of the 'trust' accorded to the academic community" (Newton, 2002, p. 41). Various researchers found that staff experienced loss of ownership and pride as well as reduced individual professional responsibility and accountability, effects that were perceived as impeding new developments and innovation, discouraging young academics and withdrawing creative energy from senior staff who cooperated reluctantly and played the game (Watty, 2002; Newton, 2002; Cartwright, 2007; Findlow, 2008). Staff perceived a tendency to emphasise measurable aspects of quality, tick-box items that are easy to identify irrespective of their relevance to quality, while the really relevant issues are being neglected. It was concluded that organisations may (over)analyse whether things are being done well, while failing to assess whether the right things are being done (Koch, 2003; Cartwright, 2007).

Other authors, however, have pointed to positive effects of quality management, although empirical evidence remains scarce. They claim that quality management can emphasise responsibility and break through prevailing internal orientations, that it subjects activities to critical review from outside and leads to more attention to the teaching function of departments and the teaching methods used (Westerheijden, 1999; Brennan \& Shah, 2000; Huisman \& Currie, 2004; Stensaker, 
2007; Westerheijden, Hulpiau \& Waeytens, 2007; Lanarès, 2008). Furthermore, they claim a reinforcement of the organisation: students are empowered when their perspectives and interests are taken into consideration, institutions and departments are stimulated to underpin their decisions by more transparent and open information (Brennan \& Shah, 2000) and there is "a constraint on arbitrary power" (Huisman \& Currie, 2004, p. 531). And, finally, quality management and transparency may raise public trust in the organisation: "Trust is built on verification and grows as a spiral" (Lanarès, 2008, p. 4). However, scientific evidence for these positive views is lacking (Hulpiau \& Waeytens, 2001; Westerheijden, Hulpiau \& Waeytens, 2007).

\section{Organisational values}

In the two preceding sections, it was explained that judgments of the effectiveness of quality management depend on conceptions of quality and the way quality management is organised. In addition to this, literature also assumes that conceptions and perceptions of quality and quality management are embedded in the culture and values of an institution (Harvey \& Green, 1993; Cameron \& Quinn, 1999; Kezar \& Eckel, 2002; Lomas, 2004; EUA, 2006). Sitkin, Sutcliffe and Schroeder (1994) postulate that quality management endeavours frequently falter because they fail to address the specific circumstances of the organisation. Successes in one organisation are all too easily seen as a universal remedy for all the quality problems plaguing other organisations. Similar findings were presented by Cameron and Quinn (1999, pp. 7-8). Following extensive field research, they conclude that quality management strategies frequently fail to meet expectations. In their opinion, organisational culture and related organisational values may be the prime factor determining the success or failure of quality management strategies. The importance of organisational culture and values is also emphasised by Pirsig (1974), Harvey and Green (1993), Kezar and Eckel (2002) Jouslin de Noray (2004) and Van Kemenade, Pupius and Hardjono (2008). Values are seen as a core element of culture (Hofstede, 2001). They are desirable motivational goals that touch upon all spheres of life, transcend any situation and are the guiding principles by which people can lead their day-to-day lives and by which they assess situations and behaviour (Hitlin \& Piliavin, 2004).

Quinn and Rohrbaugh (1983) and Quinn et al. (1996) developed the 'competing values framework' to study values relating to the functioning of organisations (Figure 1). The theoretical basis underlying this framework has been amply validated, also in the context of higher education (Howard; 1998; Cameron and Quinn, 1999). The framework incorporates three strategic dimensions of organisations. The first dimension is related to focus, i.e. internal versus external orientation, and can be well applied to the education domain. Some institutes focus primarily on internal 
processes, others place more emphasis on expectations of external stakeholders and on an external orientation. The second dimension concerns structure, i.e. control versus flexibility. This dimension, too, is applicable to the education domain. Some institutes cherish their acquired traditions and sense of professionalism, other favour experimentation and innovation. The third dimension is related to organisational means and ends and reflects the degree of closeness to the desired organisational results. Target values approximate the 'ideal situation' and are extensive and difficult to realise. Means-related values tend to be less extensive and are easier to accomplish. High quality is an example of a target value, while planning and formulating goals and targets are examples of means values.

\section{Flexibility}

\begin{tabular}{l|l} 
HUMAN RELATIONS MODEL & OPEN SYSTEM MODEL \\
Means: dedication, cohesion, morale & $\begin{array}{c}\text { Means: flexibility, readiness to } \\
\text { change, innovation }\end{array}$ \\
Ends: $\begin{array}{l}\text { participation, openness, } \\
\text { involvement, human resource } \\
\text { development } \\
\text { Internal }\end{array}$ & $\begin{array}{l}\text { growth, external } \\
\text { support, resource } \\
\text { acquisition }\end{array}$ \\
Means: information management, \\
communication, measurement
\end{tabular}

Figure 1. Typology of organisational values (Reitsma, 2003, p. 16), based on Quinn and Rohrbaugh (1983) and Quinn et al. (1996)

The two dimensions, 'internal versus external orientation' and 'control versus flexibility' result in four quadrants, each representing an ideal type of values (Quinn and Rohrbaugh, 1983; Cameron and Quinn, 1999) linked to different traditions in organisational theory (Quinn et al., 1996; Patterson et al., 2005). Within each quadrant, a distinction is made between means and ends. Thus the framework consists of two control-oriented value models: the Rational Goal model (RG) or market has an external focus and is linked to the theory of Scientific Management. The second control-oriented model is the Internal Process model (IP) or hierarchy and has an internal focus. This model is based on Weber's theories about bureaucratic structure and 
Fayol's management principles, stressing the functions of planning, organising, commanding, coordinating and controlling (Quinn et al., 1996). Control oriented organisations cherish their acquired traditions. They adopt strict rules and work methods and attach considerable importance to approved professional skills. In addition, the framework comprises two flexibility-oriented value models: the $\mathrm{Hu}$ man Relations model (HR) or clan which has an internal focus and is based on the Human Relations theory, and the external Open System model (OS) or adhocracy. This model is based on the dynamic network or systems theory and on contingency theory (Quinn et al., 1996). Flexibility oriented organisations value openness and innovation, create opportunities and take risks.

Although values are guiding principles in life, there is often a wide gap between what people think, the values that people prefer and espouse on the one hand, and what they do, the values they actually practice on the other hand (Brunsson, 1989; Argyris, 1990; Cartwright, 2007; Berings, 2009). Therefore, Cameron and Quinn (1999) make a distinction between preferred and current organisational values. They contend that every organisation tends to be characterised by one of the four value models, although these are not mutually exclusive. In fact, they are in competition with one another. They also claim that organisational culture influences how people within the organisation think about quality and internal quality management. Control-oriented values are supposed to have a positive correlation with the conception of quality as compliance with standards, whereas the flexibility-oriented values are supposed to correlate positively with enhancement and improvement. Empirical evidence for this relationship is needed for both the preferred and the current values.

\section{Research on organisational values}

The past ten years have seen a growing interest in organisational culture and values and their relationships with quality management (EUA, 2006 and 2010; Gordon and Owen, 2008; Lanarès, 2008; Harvey and Stensaker, 2008) resulting in frequent references to a quality culture (Yorke, 2000; Lomas, 2004; Vettori et al., 2007; EUA, 2006 and 2010; Fischer-Bluhm, 2007; Harvey and Stensaker, 2008; Lanarès, 2008; Berings et al., 2011; Dolmans et al., 2011). Lanarès (2008) defines quality culture as a subculture of the organisational culture. Several aspects of the quality culture and of organisational values have been researched. The first aspect relates to the quality culture and quality values that are characteristic of higher education. Cameron and Freeman (1991) conducted a widespread survey study of organisational culture within 334 institutes of higher education in the United States $(N=3,406)$. No institute was characterised by only one culture. However, the values of the human relations model were found most frequently and the values of the rational goal model occurred least frequently. Berings et al. (2011) performed a pilot study among 28 (sub)organisations of higher education in Belgium (university colleges and universi- 
ties) with two diagnoses per (sub)organisation. Although using value categories that differed from those of Cameron and Quinn (1999), they reported similar findings: collective and people oriented organisational values were the most preferred values, followed by values of innovation, coordination and formalisation.

The impact on the organisation is a second aspect of organisational values that has been researched. In the literature, it is often stated that quality is fostered by communication, participation, a combination of top-down and bottom-up interaction (Ehlers, 2009) and other values related to a learning organisation, such as responsibility, empowerment and reflection (Lanarès, 2008). Cameron and Freeman (1991, p. 45) found that human relations cultures scored highest on students' educational and personal satisfaction, faculty satisfaction and organisational health. Open system cultures scored highest on students' academic and career development, professional development of staff and system openness. Rational goal cultures scored highest on the ability to acquire resources ( $p$ always $<0.05$ ). In a survey among 44 (sub)organisations of higher education (university colleges and universities), Berings (2009, p. 13) found that current collective and people oriented values, and values of innovation, i.e. the flexibility oriented values, but also system values were significantly positively related with student and employee satisfaction.

A third aspect of research into organisational culture and values concerns their relationship with individual and organisational barriers to the implementation of quality management and change. Values that are widely preferred are often blocked by defence mechanisms and structural barriers like faulty communication channels, large hierarchical distances or financial constraints (Mundet Hiern et al., 2006; Harvey, 2007; EUA, 2010). Mundett Hiern et al. (2006) analysed the perceptions of middle managers in several companies obtained from a written questionnaire and found that the following barriers impeded organisational change: lack of trust due to labour instability and dissatisfaction with the result of actions and faulty communication channels due to large hierarchical distances. These barriers induced concealment of facts by convenient but deceptive speech and refraining from expressing ideas that were seen as deviant from the ideas of management or the majority. Cruickshank (2003) conducted a literature review of barriers to Total Quality Management (TQM), which she described as continuous quality improvement regarding the three main aspects of quality of education: design, conformance and performance. The few studies that she found were mostly case studies, and from these she derived the following barriers: negative attitudes towards "the application of TQM within universities", "scepticism for management fads", a culture that generally nurtures, recognises and rewards individual accomplishments more than group, organisational or community achievements and resistance to external interference and the introduction of new management techniques (Cruickshank, 2003, pp. 11611162). She concluded: "If the application of Total Quality Management in the higher education industry is to be successful, two fundamental areas will need to be ad- 
dressed. Firstly, assessing the culture of higher education institutions and introducing changes in attitudes, values and beliefs will be paramount." Secondly, universities will also have to choose "a balance between its old and new cultures" (Cruickshank, 2003, p. 1164-1165). Because the existing academic culture is valuable as well, she recommended that quality management should be implemented and developed "within the framework of the existing culture, rather than going to war with it" (Cruickshank, 2003, p. 1165). Vettori and Lueger (2011, p. 53) expressed the same views in a different way: "A successful $Q$ (uality) $A$ (ssurance) system is not built for the organisation, but from the organisation." It has to be built in the context of the culture that people are living in and that is a part of their identity (Harvey and Stensaker, 2008). It can be concluded that organisational culture may contain elements that are beneficial and detrimental to organisational change. Consequently, it is always necessary to study the organisational culture of institutes and departments in higher education, when quality management is introduced.

\section{Research design}

\section{Research questions and research framework}

The preceding review of the literature demonstrates that the effectiveness of integral quality management is a topic of debate, with some arguing that it is not effective at all and only increases administrative workload, and others arguing that it is effective and contributes towards continuous improvement and transformations. Overall, empirical evidence on this topic is equivocal and not convincing. There is some evidence that teachers prefer conceptions of quality aimed at enhancing and improving education, that quality management should be entrusted to all teaching staff and that flexibility-oriented organisational values are preferred. However, empirical evidence is scarce and the subject has not yet been researched in the context of Dutch higher education.

The following research questions are answered in this thesis:

1. What organisational values do teaching staff prefer and to what extent do they perceive these organisational values to be present in the current situation in their department? What are the differences between their perceptions of the current situation and their preferences regarding these values? And finally, are these questions answered differently in different departments? (Chapters 3 and $6)$.

2. What are teaching staff's conceptions of quality of education? Do they have a conception of quality as compliance with standards or as enhancement and im- 
provement? Are there relationships between their conceptions of quality and their preferred organisational values? (Chapters 4 and 6).

3. According to teaching staff, do their departments pay sufficient attention to relevant quality aspects and do they undertake sufficient quality management activities? Do departments differ in relation to these issues? (Chapters 5 and 6).

4. Do teaching staff think that quality management within their department makes an effective contribution to educational improvement or that it strengthens central control? Do departments differ in the answers to this question? (Chapters 5 and 6).

5. Is there a relationship between perceived effectiveness of quality management, performance of quality management activities and the organisational values that are current within departments? (Chapters 5 and 6).

The relationships between the research questions are illustrated in the research framework in Figure 2. The upper part represents conceptions: conceptions of preferred organisational values and conceptions of quality. The lower part relates to practice: current organisational values, which are in fact being put into practice, performed quality management activities and the effectiveness of quality management. The conceptions and practice are examined within the contexts of different departments. The arrows in the figure indicate possible relationships between variables. The cited chapters present quantitative and qualitative studies of the variables and their mutual relationships.

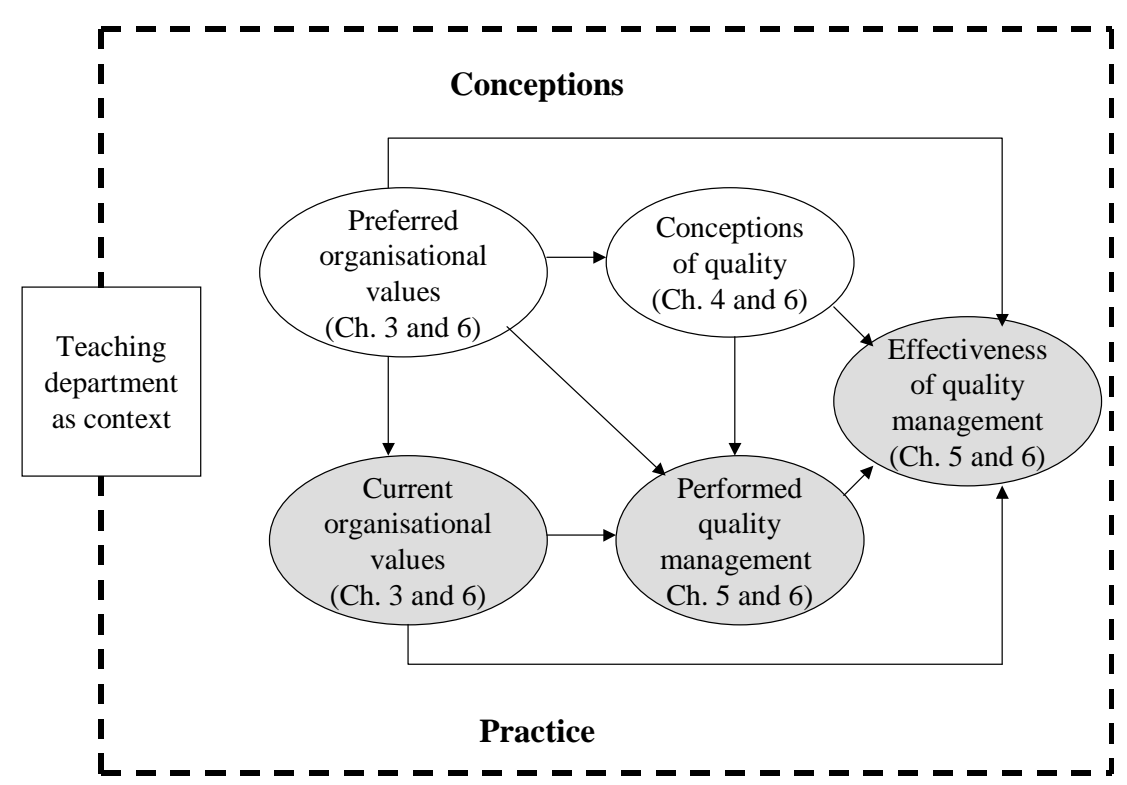

Figure 2. Research framework 


\section{Research methods}

The research in this thesis consists of the main, quantitative study and an additional qualitative study. The quantitative study is based on a survey conducted between March and September 2008 among teachers in six different sectors of universities of applied sciences in the Netherlands: economics and business administration, health care, education (teacher training), social welfare, engineering and technology and fine and performing arts. Data were collected per teaching department to enable comparisons between departments and educational domains. This quantitative study is reported in Chapters 3-5 included.

The Netherlands has a binary system of higher education with traditional universities and universities of applied science (UAS). Forty universities of applied sciences are accredited and funded by the government and offer curricula leading to bachelor's and master's degrees in a wide range of subjects. They are organised in departments and have a student population of over 400,000 students (HBO-Raad, 2010). For reasons of homogeneity, this study focused on the teaching staff of bachelor programmes. Of the total of 991 questionnaires sent out to the entire teaching staff of thirty departments 316 (32\%) were returned. The analysis was limited to the questionnaires completed by 266 respondents from eighteen departments with ten or more respondents.

An important methodological issue in research is determining the population and the units to be studied and the appropriate levels of analysis and sampling. This issue has to be considered in relation to the main research questions in the conceptual research framework (Berenson \& Levine, 1983). In this study there are two groups of research questions: questions about the conceptions and perceptions of individual members of UAS teaching staff and questions about differences between departments. In answering the latter group of questions, the department is the unit of analysis and the research population consists of all departments with bachelor programmes within Dutch UAS. Within the departments individual staff members are the unit of analysis. Hence a two-step sample was considered appropriate (Segers \& Hagenaars, 1980). The study sample did not achieve a balanced distribution over the educational sectors (see Table 1, Chapter 3, p. 49).

The selection and operationalisation of variables and the wording of the statements in the questionnaire are largely based on the review of the literature. The questions about the organisational culture were, with the authors' consent, adopted from the Organizational Culture Assessment Instrument (OCAI) of Cameron and Quinn (1999). The questions about conceptions of quality were derived from the various concepts of quality of Harvey and Green (1993) and the questions about attention paid to the various aspects of quality were derived from the distinction between input factors, processes and outputs. The questions about quality management activities concerned the design of educational programmes, quality assessment, quality assurance and elements of Total Quality Management. The ques- 
tions about of the effectiveness of internal quality management were derived from the positive and negative effects reported in the literature. Current values, attention paid to quality aspects, performance of quality management activities and effectiveness of internal quality management were inferred from perceptions of teaching staff. The questionnaire contained a total of one hundred items. Except for the nine background questions, all items were formulated as statements and participants were asked to indicate their agreement on a five-point Likert scale (1=fully disagree; $5=$ =fully agree; $3=$ neutral).

A choice had to be made between ranking or rating scale items. Because of the competing character of organisational values and in order to create clear value profiles for different organisations, Cameron and Quinn (1999) recommend a ranking scale when using the OCAl, but Quinn also used the questionnaire as a Likert type rating scale, concluding that both methods had advantages and disadvantages (Cameron and Quinn, 1999, p. 145). In order to decide between the two scales, a pilot study was conducted before the main study, with two groups of respondents, each completing a different questionnaire. Based on the results of this pilot, indicating unequivocally a better suitability of the rating scale response format, it was decided to use the Likert type rating scale items in the main study.

In 2010, a supplemental qualitative study was carried out to go deeper into the findings of the quantitative study with the aim of investigating whether or not the findings from the quantitative study were substantiated and complemented by the additional qualitative information (triangulation, Flick, 1992; Yin, 2003). The qualitative study was performed in six of the eighteen departments that had participated in the quantitative study. Of these departments, three had shown high and three had shown low scores on perceived improvement as a result of quality management. In each of these six departments, individual interviews were conducted with the director or manager of the teaching department and with two senior members of the teaching staff. The interviews were guided by eight semi-structured questions.

\section{References}

Ahaus, Kees. (2006). Kwaliteit uit waardering [Quality through appraisal]. Inaugural address held at the Faculty of Management and Organization of the University of Groningen on acceptance of his appointment to the endowed chair of Quality Management at the Management Science department on Tuesday 4 April 2006. Groningen: Rijksuniversiteit Groningen: Faculteit Bedrijfskunde.

Argyris, C. (1990). Overcoming organizational defenses. Facilitating organizational learning. Boston, London, etc.: Allyn and Bacon.

Barnett, R. (2003). Beyond all reason: living with ideology within the university. Buckingham: The Society for Research into Higher Education and Open University Press.

Becket, N., \& Brookes, M. (2006). Evaluating quality management in university departments. Quality Assurance in Education, 14(2), 123-142. 
Berenson, M.L,. \& Levine, D.M. (1983). Basic business statistics: concepts and applications (2 ${ }^{\text {nd }}$ ed.). Englewood Cliffs, New Jersey: Prentice-Hall, Inc.

Berings, D. (2009). Reflection on quality culture as a substantial element of quality management in higher education. Paper presented at the 4th European Quality Assurance Forum. Copenhagen, Denmark.

Berings, D., Beerten, Z, Hulpiau, V., \& Verhesschen, P. (2011). Quality culture in higher education: from theory to practice. In EUA, Building bridges: making sense of quality assurance in European, national and institutional contexts. A selection of papers from the 5th European Quality Assurance Forum, 1820 November 2010, Lyon, France (pp. 38-49). Brussels, Belgium: EUA.

Brennan, J., \& Shah, T. (2000). Quality assessment and institutional change: experiences from 14 countries. Higher Education 40, 331-349.

Brundrett, M., \& Rhodes, C. (2011). Leadership for quality and accountability in education. London and New York: Routledge.

Brunsson, N. (1989). The organization of hypocrisy. Talk, decisions and actions in organizations. Chichester, New York etc.: John Wiley \& Sons.

Cameron, K.S., \& Freeman, S.J. (1991). Cultural congruence, strength, and type: relationships to effectiveness. Research in Organisational Change and Development, 5, 23-58.

Cameron, K. S., \& Quinn, R. E. (1999). Diagnosing and changing organizational culture. Based on the competing values Framework. Reading, MA [etc.] : Addison-Wesley.

Cartwright, M.J. (2007), The rhetoric and reality of 'quality' in higher education. An investigation into staff perceptions of quality in post-1992 universities. Quality Assurance in Education, 15(3), 287-301.

Cave, M., Hanney, S., Henkel, M., \& Kogan, M. (1997). The use of performance indicators in higher education. The challenge of the quality movement ( $3^{\text {rd }}$ ed.). London: Jessica Kingsley Publishers.

Cruickshank, M. (2003). Total quality management in the higher education sector: a literature review from an international and Australian perspective. TQM \& Business Excellence, 14(10), 1159-1167.

Dolmans, D.H.J.M., Stalmeijer, R.E., Van Berkel, H.J.M., \& Wolfhagen, H.A.P. (2011). Quality assurance of teaching and learning: enhancing the quality culture. In T. Dornan, K. Mann, A. Scherpbier \& J. Spencer (Eds.), Medical education. Theory and practice (pp. 257-264). Edinburgh: Elsevier.

Ehlers, U.D. (2009). Understanding quality culture. Quality Assurance in Education, 12(4), 343-363.

EUA, European University Association. (2006). Quality culture in European universities: a bottom-up approach. Report on the three rounds of the Quality Culture Project 2002-2006. Brussels, Belgium: EUA.

EUA. European University Association. (2010). Examining quality culture: part I - Quality assurance processes in higher education institutions. Brussels, Belgium: EUA.

Findlow, S. (2008). Accountability and innovation in higher education: a disabling tension? Studies in Higher Education, 33(3), 313-329.

Fischer-Bluhm, K. (2007). Instruments for raising quality culture in a network of universities. In European University Association, Embedding quality culture: A selection of papers from The 1st European Forum for Quality Assurance, 23-25 November 2006 (pp. 34-40). Brussels, Belgium: EUA.

Flick, U. (1992). Triangulation Revisited: strategy of validation or alternative? Journal of the Theory of Social Behaviour, 22(2), 175-197.

Garvin, D.A. (1988). Managing quality. The strategic and competitive edge. New York, London: The Free Press.

Gibson, A. (1986). Inspecting education, in G.C. Moodie (Ed.), Standards and criteria in higher education (pp. 128-135). Milton Keynes: SRHE \& Open University Press.

Gordon, G., \& Owen, C. (2008). Cultures of quality enhancement: a short overview of the literature for higher education policy makers and practitioners. Available at www.enhancementthemes.ac.uk (accessed 20 October 2011).

Grant, D., Mergen, E., \& Widrick, S. (2004). A comparative analysis of quality management in US and international universities. Total Quality Management, 15(4), 423-438. 
Harvey, L. (2007), Quality culture, quality assurance and impact. Overview of discussions. In EUA, Embedding quality culture in higher education. A selection of papers from the 1st European Forum for Quality Assurance, München, Germany, 23-25 November 2006. EUA, Brussels, pp.81-84.

Harvey, L., \& Green, D. (1993). Defining quality. Assessment \& Evaluation in Higher Education, 18(1), 934.

Harvey, L., \& Newton, J. (2004). Transforming quality evaluation. Quality in Higher Education, 10(2), 149165.

Harvey, L., \& Newton, J. (2007). Transforming quality evaluation: moving on. In D.F. Westerheijden, B. Stensaker \& M.J. Rosa (Eds.), Quality assurance in higher education. Trends in regulation, translation and transformation (pp. 225-245). Dordrecht, The Netherlands: Springer.

Harvey, L., \& Stensaker, B. (2008). Quality culture: understandings, boundaries and linkages. European Journal of Education, 43(4), 427-442.

HBO-Raad. (2010). The Netherlands Association of Universities of Applied Sciences, Den Haag: HBO-Raad. Available at: www.hbo-raad.nl/english (accessed 5 January 2011).

Hitlin, S., \& Piliavin, J. A. (2004). Values: reviving a dormant concept. Annual Review of Sociology, 30, 359393.

Hofstede, G. (2001). Culture's consequences: comparing values, behaviors, institutions and organizations across nations ( $2^{\text {nd }}$ ed.). Thousand Oaks, Ca (etc.), Sage.

Houston, D. (2008). Rethinking quality and improvement in higher education. Quality Assurance in Education, 16(1), 61-79.

Howard, G. (1998). Validating the competing values model as a representation of organizational cultures. International Journal of Organizational Analysis, 6(3), 231-250.

Huisman, J., \& Currie, J. (2004). Accountability in higher education: Bridge over troubled water? Higher Education, 48(4), 529-551.

Hulpiau, V., \& Waeytens, K. (2001). Improving Quality of education: what makes it actually work? A case study. Paper presented at the International Research Conference 'Higher Education Close Up', July 16-18 2001. Lancaster: Lancaster University.

INK. (2008). Introductie. Inhoud en toepassing van het INK-managementmodel [Introduction. Theory and practice of the INK management model] . Zaltbommel: INK.

Jouslin de Noray, B. (2004). Theory and techniques on breakthrough change. Proceedings of the 48th Congress of the European Organisation for Quality, Moscow. Brussels, Belgium: EOQ.

Kezar, A., \& Eckel, P. D. (2002). The effect of institutional culture on change strategies in higher education. Universal principles or culturally responsive concepts? Higher Education, 73(4), 435-460.

Koch, J.V. (2003). TQM: why is its impact in higher education so small? The TQM Magazine, 15(5), 325333.

Lanarès, J. (2008). Developing a quality culture. In E. Froment, J. Purser \& L. Wilson (Eds.), EUA Bologna Handbook (C 2.101, pp. 1-27). Berlin: Raabe Verlag.

Lewis, R. G., \& Smith, D. H. (1994). Total quality in higher education. Delray Beach Florida: St. Lucie Press.

Lomas, L., (2004). Embedding quality: the challenges for higher education. Quality Assurance in Education, 12(4), 157-165.

Lomas, L. (2007). Zen, motorcycle maintenances and quality in higher education. Quality Asurance in Education, 15(4), 402-412.

Milliken, J., \& Colohan, G. (2004). Quality or control? Management in higher education. Journal of Higher Education Policy and Management, 26(3), 381-391.

Mundet Hiern, J., Suñé Torrents, A., Sallán Leyes, J.M., \& Fernández Alarcón, V. (2006). The impact of defensive barriers on organizational performance and learning. Management \& Avenir, 2(8), 27-37.

Newton, J. (2000). Feeding the beast or improving quality?: academics' perceptions of quality assurance and quality monitoring. Quality in Higher Education, 6 (2), 153-163.

Newton, J. (2002), Views from below: academics coping with quality. Quality in Higher Education, 8(1), 39-61. 
Newton, J. (2007). What is quality? In EUA, Embedding quality culture in higher education. A selection of papers from the 1st European Forum for Quality Assurance, 22- 25 November 2006 (pp. 14-20). Brussels, Belgium: EUA.

Nicholson, K. (2011). Quality assurance in higher education. A review of literature. Available at http://cll.mcmaster.ca/COU/pdf/Quality\%20Assurance\%20Literature\%20Review.pdf. (accessed 20 October 2011).

Owlia, M.S., \& Aspinwall, E.A. (1996). Quality in higher education. Total Quality Management, 7(2), 161171.

Parasuraman, A., Berry, L.L., \& Zeithaml, V.A. (1991). Refinement and reassessment of the Servqual scale. Journal of Retailing, 67(4), 420-450.

Parri, J. (2006). Quality in higher education. Vadyba / Management, 2(11), 107-111.

Patterson, M.G., West, M.A., Shackleton, V.J. Dawson, J.F. , Lawthom, R., Maitlis, S., Robinson D.L., \& Wallace, A.M. (2005). Validating the organizational climate measure: links to managerial practices, productivity and innovation. Journal of Organizational Behavior 26(4), 379-408.

Pirsig, R.M. (1974). Zen and the art of the motorcycle maintenance. An inquiry into values. New York: Bantam Book.

Quinn, R.E., \& Rohrbaugh, J. (1983). A spatial model of effectiveness criteria: towards a competitive values approach to organizational analysis. Management Science, 29, 363-377.

Quinn, R.E., Faerman, S.R., Thompson, M.P., \& McGrath, M.R. (1996). Becoming a master manager: $A$ competency framework ( $2^{\text {nd }}$ ed.). New York (etc.): Wiley.

Reitsma, A. (2003). Kritische succesfactoren bij visitatie en kwaliteitsverbetering van P\&A-opleidingen. Casestudy onderzoek [Critical success factors in visitation and quality improvement of personnel management programmes. A case-based research approach]. Heerlen: Open Universiteit.

Rust, R.T., \& Olivers, R.L. (1994). Service Quality. Insights and managerial implications from the frontier. In R.T. Rust \& R.L. Olivers (Eds.), Service quality. New directions in theory and practice (pp. 1-20). Thousand Oaks, London, New Delhi: Sage Publications.

Sahney, S., Banwet, D.K. \& Karunes, S. (2004). Conceptualizing total quality management in higher education, The TQM Magazine, 16(2), pp. 145-159.

Sallis, E. (1996 and 2002). Total quality management in education $\left(2^{\text {nd }}\right.$ and $3^{\text {rd }}$ ed.). London: Kogan Page.

Segers, J.H.G., \& Hagenaars, J.A.O. (Eds). (1980). Sociologische onderzoeksmethoden, deel II. Technieken van Causale Analyse [Methods of sociological research, part II. Techniques of causal analysis]. Assen, The Netherlands: Van Gorcum.

Segers, M.S.R. (1993). Kwaliteitsbewaking in het Hoger Onderwijs. Een exploratieve studie naar prestatieindicatoren in theorie en praktijk. Proefschrift [Quality assessment in higher education. An explorative study into performance indicators in theory and practice. Dissertation]. Maastricht, The Netherlands: Maastricht University.

Sitkin, S.B., Sutcliffe, K.M., \& Schroeder, R.G. (1994). Distinguishing control from learning in Total Quality Management: a contingency perspective. Academy of Management review, 18(3), 537-564.

Stensaker, B. (2007). Impact of quality processes. In EUA, Embedding quality culture in higher education. A selection of papers from the 1st European Forum for Quality Assurance, 22- 25 November 2006 (pp.59-62), Brussels, Belgium: EUA.

Tam, M. (2001). Measuring quality and performance in higher education. Quality in Higher Education, 7(1), 47-54.

Van Damme, D. (2004). Standards and indicators in institutional and programme accreditation in higher education: a conceptual framework and a proposal. In L. Vlasceanu \& L.C. Barrows (Eds.), Indicators for institutional and programme accreditation in higher/tertiary education (pp. 127-159). Bucharest: UNESCO-CEPES.

Van der Bij, H., Broekhuis, M., \& Gieskes, J. (2001). Kwaliteitsmanagement in beweging. Van blauwdruk naar contingenties en dynamiek [Quality management on the move, from blueprint to contingencies and dynamics] ( $2^{\text {nd }}$ revised edition). Deventer, the Netherlands: Kluwer. 
Vanhoof, J., \& Van Petegem, P. (2007). Matching internal and external evaluation in an era of accountability and school development: Lessons from a Flemish perspective. Studies in Educational Evaluation, 22(2), 101-119.

Van Hout, H. (2006) Kwaliteitszorg in het HO: nog veel werk aan de winkel. [Quality assurance in higher education: much remains to be done]. In H. van Hout, G. ten Dam, M. Mirande, C. Terlouw \& J. Willems (Eds.), Vernieuwing in het hoger onderwijs. Onderwijskundig handboek (pp. 215-228) [Innovation in higher education. Education handbook (pp. 215-228)]. Assen, The Netherlands: Van Gorcum.

Van Kemenade, E., Pulpius M, \& Hardjono, T.W. (2008). More value to defining quality. Quality in Higher Education, 14(2), 175-185.

Vettori, O., Lueger, M., \& Knassmüller, M. (2007), Dealing with ambivalences - strategic options for nurturing a quality culture in teaching and learning. In EUA, Embedding quality culture in higher education. A selection of papers from the 1st European Forum for Quality Assurance, 22- 25 November 2006 (pp. 11-13). Brussels, Belgium: EUA.

Vettori, O., \& Lueger, M. (2011). No short cuts in quality assurance - Theses from a sense-making perspective. In EUA, Building bridges: making sense of quality assurance in European, national and institutional contexts. A selection of papers from the 5th European Quality Assurance Forum, 18-20 November 2010, Lyon, France (pp. 50-55). Brussels, Belgium: EUA.

Vroeijenstijn A.I., (1990). Kwaliteitswaarborg door interne en externe kwaliteitszorg [Quality assurance through internal and external quality management]. In G.W.H. Heijnen, T.H. Joostens \& A.I. Vroeijensteijn (Eds.), Kwaliteitszorg, waarborg voor kwaliteit in het hoger onderwijs [Quality management, assuring the quality of higher education] (pp. 273-289). Groningen, The Netherlands: COWOG.

Vroeijenstijn, A.I. (1995). Improvement and accountability, navigating between Scylla and Charybdis. Guide for external quality assessment in Higher Education. London and Bristol, Pennsylvania: Jessica Kingsley Publishers.

Watty, K. (2002). Engaging grassroots academics in quality conversations and quality initiatives: opportunities lost? Outline. Paper presented at the International Conference on Transforming Quality: Seventh quality in higher education international seminar, 31 October - 1 November, Melbourne, Australia. Available at: http://www.qualityresearchinternational.com/tq/papers/wattyoutline.doc.doc (accessed 1 July 2010).

Watty, K. (2006). Want to know about quality in higher education? Ask an academic. Quality in higher education, 12(3), 291-301.

Westerheijden, D.F. (1999). Where are the quantum jumps in quality assurance? Developments of a decade of research on a heavy particle. Higher Education, 38(2), 233-254.

Westerheijden, D.F., Hulpiau, V. \& Waeytens, K. (2007). From design and implementation to impact of quality assurance: an overview of some studies into what impacts improvement. Tertiary Education and Management,13(4), 295-316.

Wiklund, H., Klefsjö, B., Sandvik Wiklund, P. \& Edvardsson, B. (2003). Innovation and TQM in Swedish higher education institutions - possibilities and pitfalls. The TQM Magazine, 15(2), 99-107.

Wolfhagen, I., Dolmans, D., Bastiaens, T., \& Scherpbier, A. (2002). Interne Kwaliteitszorg in Ontwikkeling [Developing internal quality management]. Groningen/Houten, The Netherlands: WoltersNoordhoff.

Yin, R.K. (2003). Case study research. Design and method ( $3^{\text {rd }}$ ed.). London: Sage Publications.

Yorke, M. (2000). Developing a quality culture in higher education. Tertiary Education and Management, 6(1), 19-36.

Zbaracki, M. J. (1998). The rhetoric and reality of total quality management. Administrative Science Quarterly, 43(3): 602-636. 


\section{CHAPTER 3 \\ Organisational values in higher education}

Perceptions and preferences of staff ${ }^{1}$

${ }^{1}$ Published as: Kleijnen, J., Dolmans, D., Willems, J., Muijtjens, A., \& Van Hout, J. (2009). Organisational values in higher education: perceptions and preferences of staff. Quality in Higher Education 15(3), 233249. 


\begin{abstract}
In this paper, staff members' perceptions about the organisational culture are measured. The questions addressed are: what are their opinions about the current and preferred organisational culture? Are there differences between the current and preferred situation? Do the perceptions differ per department? The Organizational Culture Assessment Instrument was sent to staff involved in 18 different departments within Dutch universities of applied science. The results demonstrated that both a flexibility and control-oriented culture were moderately experienced in practice. In addition, significant differences were found between the current and preferred situation as well as a significant variation over departments for the current situation. Staff members in general, prefer a flexibility-oriented culture to a control-oriented culture. These findings imply that the organisational culture in many departments is not yet fully in line with the staff members' preferences.
\end{abstract}

Keywords: organisational culture; competing organisational values; staff perceptions; Organizational Culture Assessment Instrument 


\section{Introduction}

Within Dutch higher education, a considerable amount of time and energy is spent on internal and external quality management. The aim is to improve the quality of programmes and examination and assessment procedures, to raise overall graduation rates and to promote and facilitate public accountability (Perellon, 2007). In addition, quality management is geared towards improving the quality and competencies of lecturers (Stensaker, 2007) and promoting a culture of quality that permeates all aspects of the institute. Nevertheless, in several documents concerns are raised about the positive effects of quality management strategies (Van der Zee, 1990; Wetenschappelijke Raad voor het Regeringsbeleid, 2004; Van Hout, 2006). Does the implementation of a quality management programme actually improve the quality of the education provided? Might quality monitoring not practically result in 'ritualism', with participants engaged in collecting data simply to satisfy external accountability requirements and to 'feed the beast', without doing anything constructive with the information (Newton, 2000)? Do quality management policies support the work of professionals or do they hinder performance? Might quality management practices actually increase unnecessary bureaucracy?

The effectiveness of quality management is explored in various research papers and publications (Brennan \& Shah, 2000; Newton, 2001; Harvey \& Newton, 2004; Ahaus, 2006; Westerheijden et al., 2007). Sitkin et al. (1994) postulate that quality management endeavours frequently falter because they fail to address the specific circumstances of the organisation. Successes in one organisation are all too easily seen as a universal remedy for all the quality problems plaguing other organisations. As evidenced by recent publications, researchers continue to question whether quality management is nothing more than a fashionable but passing fad (Stensaker, 2007). Zbaracki (1998) shows how acquired insights into quality management can easily turn into a hotbed of ineffectual rhetoric: managers enthusiastically embrace solutions devised for other companies, without assessing whether such solutions are suitable for their own organisation. Cameron and Quinn (1999, pp. 7-8) present similar findings. Following extensive field research, they concluded that quality management strategies frequently fail to meet expectations. In their opinion, organisational culture is the prime factor determining the success or failure of quality management strategies. They presuppose that organisational values are an important part of organisational culture. The importance of organisational culture and values are also emphasised by Pirsig (1974), Harvey and Green (1993), Kezar and Eckel (2002) Jouslin de Noray (2004) and Van Kemenade et al. (2008). Newton (2000) postulates that 'there is a need to focus on what academics think and do, and what meanings they attach to different facets of policy . . ' . This paper is part of a research study that examines whether internal quality management processes have an influence on the quality of the departments and what influences organisa- 
tional values have on quality management practices. The scope of this research paper is limited to the issue of 'organisational values' and is explorative in nature.

\section{Organisational values}

Values are '(a) concepts or beliefs, (b) about desirable end states or behaviours, (c) that transcend specific situations, (d) guide selection or evaluation of behaviour and events, and (e) are ordered by relative importance' (Schwartz \& Bilsky 1987, p. 551). Values are a core element of culture (Hofstede, 2001, p. 10). Values are desirable, motivational goals. They transcend any situation. They vary in importance, yet are a guiding principle in people's lives. Values bridge the gap between emotions and rational thinking (information), encouraging the individual to take action. 'Values serve as latent guides for evaluations of the social world without themselves requiring much reflection' (Hitlin \& Piliavin, 2004, p. 365). They touch upon all spheres of life (Schwartz \& Bardi, 2001). Values can be personal, socialpolitical, religious and professional, as well as scientific and characteristic of academic discipline (Becher \& Trowler, 2001; Van Hout, 1996, Smart et al., 2000). 'Thus they provide the possibility for drawing links between the individual, social structure, and cultural levels of analysis'. Values are 'a potentially propitious arena in which to examine the reciprocal influences between social structural positions and individual functioning and decision making' (Hitlin \& Piliavin, 2004, p. 383).

In organisations, values are one of the most powerful and stable forces that influence an organisation's performance and strategic success. They are related to effective leadership styles and sources of individual power, to technology and group decision making (Howard, 1998, pp. 231-233). Nevertheless values can change gradually and organizational values change sooner than values that characterise society. Most people participate in different organisations, they change their organisational memberships and can change their organisational values (Hofstede, 2001, p. 393). Organisational values also change over time. In the early stages of an organisational life cycle, an organisation tends to be dominated by flexibility-oriented values, without formal structures. In later stages structures and standard procedures may be emphasised resulting in more control-oriented values (Cameron \& Quinn, 1999, pp. 48-50). Other factors influencing organisational values are external influences like governmental policy or new normative demands from external stakeholders. Organisations may respond by linking these new external demands to their own values and systems (Stensaker, 2004, p. 215). According to Van Kemenade et al. (2008, p. 184) an organization should find 'an equilibrium between an outside and inside orientation on the one hand and between an orientation based on control and change on the other'. Both stability and change reflect internal organisational responses to external stimuli (Berger \& Milem, 2000). 
The interest in organisational values within institutes for higher education has increased during the last decade. From 2002 to 2006 the European University Association (EUA) undertook an extensive Quality Culture Project that was aimed at identifying how internal quality culture values can be embedded and developed in institutions. It was concluded that in order to enhance educational quality permanently, a quality culture is needed, characterized by two elements: a cultural/psychological element of shared values, beliefs and expectations as well as a structural/managerial element with defined processes that enhance quality and aim at coordinating individual efforts (EUA, 2006).

\section{Theory of Competing Values}

This paper confines itself to identifying and analysing values relating to the functioning of departments in higher education. To measure and examine organisational values, it adopts the 'competing values framework' of Quinn and Rohrbaugh (1983) and Quinn et al. (1996). This framework incorporates the two strategic dimensions of Van Kemenade et al. (2008): the outside-inside and the control-change dimension. As a multidimensional construct it seems suitable to higher education and it reflects the needs of organisations at different stages in their development (Lysons et al., 1998). The theoretical framework has been tested through extensive research (Cameron \& Quinn, 1999; Howard, 1998) and corresponds to the theoretical perspectives advanced by Schwartz (1992) and empirical analyses conducted by Bilsky and Jehn (2002, p. 218). Moreover, this theoretical framework offers a rich array of techniques for examining organisational leadership and quality management (Quinn et al., 1996). The theory of competing values is a three-dimensional model.

The first dimension is related to focus, that is, internal versus external orientation, and is also applicable to the education domain. Some institutes focus primarily on their internal processes, course timetables, division of tasks and on promoting mutual collaboration and creating a positive atmosphere. Other institutes lay more emphasis on whether the goals and results correspond to the expectations of the external professional working field, whether the working field perceives teaching staff as experts in their respective fields, or whether teaching staff are capable of acting in an advisory capacity for local businesses.

The second dimension concerns structure, that is, control versus flexibility. This dimension is also applicable to the education domain. Some institutes cherish their acquired traditions and sense of professionalism. They adopt strict rules and work methods and attach considerable importance to substance. Others favour experimentation and innovation. They create opportunities and take risks. The third dimension is related to organisational means and ends. This dimension reflects the degree of closeness to the preferred organisational results. Target values approximate the 'ideal situation' and are extensive. Values related to means tend to be less 
extensive and are easier to accomplish. High productivity is an example of a target value. Planning and systematic approach are examples of means values. On the basis of these multiple dimensions, Quinn and Rohrbaugh (1983) construct a typology comprising four models (Figure 1 ).

The internal-external and control-flexibility are the most prominent dimensions and are explicitly incorporated by Cameron and Quinn (1999) in their Organisational Culture Assessment Instrument (OCAI).

\section{Flexibility}

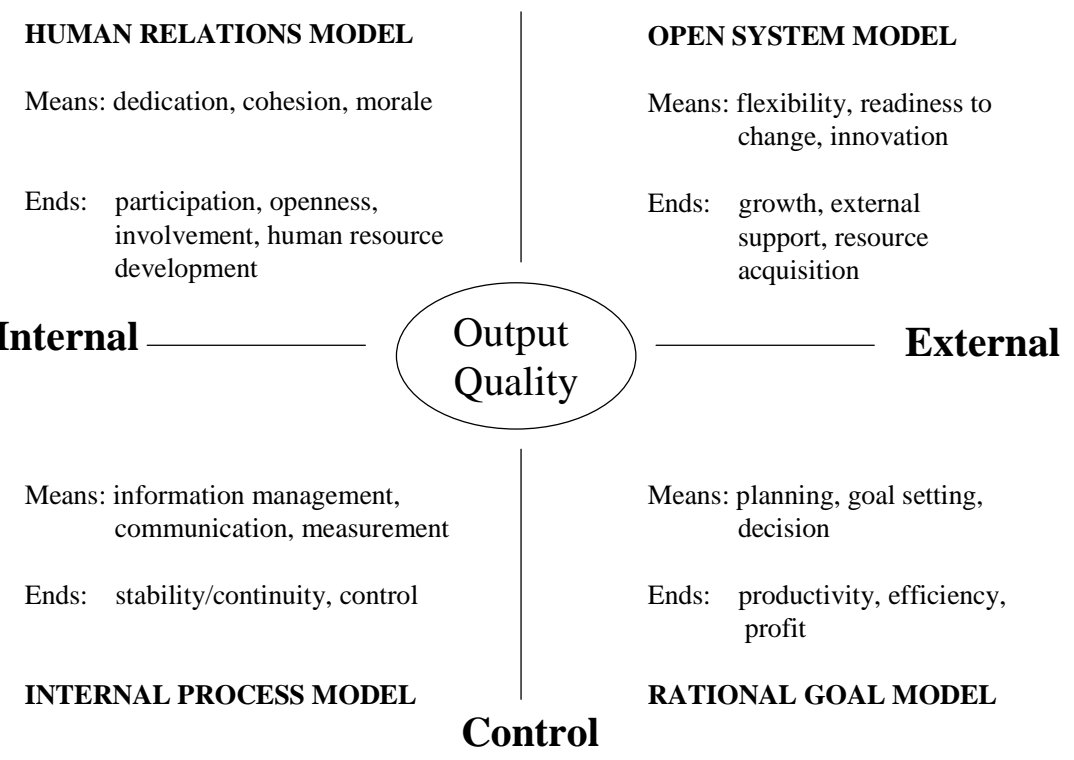

Figure 1. Typology of organisational values (Reitsma, 2003, p. 16), based on Quinn and Rohrbaugh (1983) and Quinn et al. (1996)

\section{Rational goal model}

The first model is the 'rational goal model' (RG) or 'market'. It emphasises control and has an external focus. Applied to the education domain, this model is concerned with providing relatively good education for students and with providing adequate service for the working field. What matters is satisfying the customer's basic expectations, acquiring reputation and garnering influence in the professional working field. Institutes seek to accomplish these ends at 'acceptable costs' and effort and minimally strive to balance the books (in the Netherlands, higher education is subsidised, generating profit is thus not the ultimate goal). To achieve these goals, clear targets must be formulated and a systematic approach adopted (for example, schedules for lectures, course timetables and well-defined assessmentcriteria), subject to a clear and transparent decision-making process. 


\section{Internal process model}

The second model is the 'internal process model' (IP) or 'hierarchy'. The focus is on internal control, rather than on dynamics, on stability of tasks and functions, on consistency of quality and on continuity in working methods, in the use of resources and in organisational structure. Management strives to ensure that it has a 'grip' on an organisation that is 'in control'. It strives to achieve these goals by ensuring that students and teaching staff, as well as the working field, have access to adequate and sufficient information at the appropriate time. The emphasis is on collecting information (measurement) and on information and communication management.

\section{Human relations model}

The third model is the 'human relations model' (HR) or 'clan'. It emphasises the concepts of motivation, staff development and personal relationships. The focus of this model is on internal flexibility. Institutes encourage the effort and dedication of all staff members, emphasising collaboration, staff morale, coherence and a healthy work environment where all parties have a common stake in the institute's future. Staff members are involved in the decision-making process, there is a degree of openness with regard to the provision of information and decision-making process, staff participate in important activities and are given the opportunity to deploy their talents. This model is characterised by consultative decision-making.

\section{Open system model}

The fourth and final model is the 'open system model' (OS) or 'adhocracy'. The focus of this model is on external flexibility. The institute aims to increase its market share of both student numbers and external orders. It is focussed on developing and expanding its study programme and services and its human resources and capacities. It responds to environmental developments and opportunities and, in the process, seeks to procure external support (expertise and resources). The institute attaches considerable importance to how it is evaluated by students, alumni and the professional field and to safeguarding the transparency of the services provided. It encourages and welcomes staff who adopt a flexible approach, demonstrate a willingness and ability to adapt and, above all, staff who demonstrate initiative and creativity. The key word in the mission statement of this type of institute is 'entrepreneurship'. Opportunities are explored, risks are taken.

The RG and IP are both control-oriented models, whereas, HR and OS are both flexibility-oriented models. Quinn et al. (1996) and Reitsma (2003, p. 19) advocate a balanced 'and-and' approach to the values of all four models. Institutions should both stimulate a flexibility and control-oriented culture in order to be successful. 
The highest performing leaders 'have developed capabilities and skills that allow them to succeed in each of the four quadrants' (Cameron \& Quinn, 1999, p. 42).

\section{Four research questions}

The present research aims to examine the suitability of these four models to higher education. Do any of these models dominate, or can the models be coexistent? This paper makes a distinction between the current situation and the preferred situation. Organisational values have a place in the current situation of the departments. They are 'institutional' values, deeply embedded within the organisation; this is reflected in the perceptions of staff members (lecturers and senior managers). In addition, staff members have their own opinions about the 'desirability' of organisational values. These perceptions and preferences may differ per department. In order to examine this, four research questions were formulated:

1. To what extent do the staff members perceive the four organisational value models as indicative of the current situation (C) at their department? (Current values.)

2. To what extent do the staff members consider the four organisational value models preferable (P) for their department? (Preferred values.)

3. What are the differences between the staff members' perceptions of the current situation and their preferences regarding the four models of organisational values: $\mathrm{C}$ minus $\mathrm{P}$ ? (C-P.)

4. Is there variation between the departments, with regard to organisational values, in the perception of the current situation, the preferred values, or the difference between the two, C-P?

The answers to the questions will allow for making well-substantiated pronouncements in a later stage of the research on the relationship between organisational values and quality assurance.

\section{Methodology}

\section{Context and subjects}

The Netherlands has a binary system of higher education. In addition to traditional universities, there are also universities of applied sciences, known as 'hogescholen'. The Netherlands has 40 government-approved and state-funded universities of applied sciences, with, together, over 370,000 enrolled students (HBO-raad, 2009a). Education is offered in departments. They offer a structured, cohesive yet differentiated curriculum, leading to a certain degree. In the Netherlands, all accredited 
programmes are listed in the Central Register of Higher Education Programmes (CROHO). Universities of applied sciences have departments divided into six sectors: economics and business administration; health care; education (teacher training); social welfare; engineering and technology; and fine and performing arts.

This research is based on a survey conducted between March and September 2008 in Dutch universities of applied sciences. The first step involved taking a random sample of 36 departments and approaching six departments per sector (stratified sample). Senior managers were asked to participate in the survey. Of the 36 departments, 18 were willing to participate. Later on, 18 other departments were asked to participate in this study. In total, 30 departments participated in the survey, of which in principle all lecturers and senior managers were approached. A total of 991 questionnaires were sent out; 316 (32\%) were returned. Eighteen departments had 10 or more respondents. This survey is limited to the 266 respondents from these 18 departments. The response rate of these 18 ranged from 18 to $63 \%$.

The distribution of departments and respondents over sectors is shown in Table 1. The median age of the respondents was 48.2 years and $53 \%$ of respondents were male. Respondents were asked to indicate their highest academic qualifications: $32.5 \%$ held a bachelor's degree or equivalent, $59 \%$ a master's degree or equivalent, and $4.5 \%$ a doctorate. The highest academic qualification of the remaining $4 \%$ was unknown. Two-thirds (65\%) were employed in a university of applied sciences for more than six years and $85 \%$ held an appointment of 0.5 or higher full-time equivalent. About one-third (31\%) were heavily engaged in quality management and $38 \%$ were intensively involved in recent accreditation activities. Compared with Dutch national data (HBO-Raad, 2009b), it may be concluded that with regard to age, gender and academic qualifications, the study sample was reasonably representative of universities of applied sciences in the Netherlands. In addition, based on the length of appointment in years and the appointment scale, respondents could be considered to be capable of answering the survey questions.

Table 1. Departments and respondents by sector

\begin{tabular}{lccc}
\hline Sector & Departments & Respondents & $\begin{array}{c}\text { \% of total number of } \\
\text { respondents }\end{array}$ \\
\hline Economics and Business Administration & 2 & 28 & 11 \\
Health Care & 6 & 90 & 34 \\
Education (teacher training) & 3 & 40 & 15 \\
Social Welfare & 3 & 51 & 19 \\
Engineering and Technology & 3 & 39 & 15 \\
Fine and Performing Arts & 1 & 18 & 7 \\
Total & 18 & 266 & 101 \\
\hline
\end{tabular}

Note: The percentages do not sum to 100 exactly due to rounding up. 


\section{Instrument}

To measure the dominant culture of the departments, the OCAI was translated and adopted. This questionnaire was devised by Cameron and Quinn (1999) on the basis of the competing values framework. This framework represents the four models of organisational values: HR, OS, RG and IP. The original questionnaire consists of six questions with four statements each, relating to one of the four organisational values. These four statements must be ranked according to preference (ranking-type scale). Quinn, however, also used the questionnaire as a Likert scale (rating-type) (Cameron \& Quinn, 1999, p. 145). The rating-type scale consists of 24 questions: six for each of the four organisational values. In the current study, the rating-type scale was adopted, offering five possible answers, ranging from 1 ('strongly disagree') to 5 ('strongly agree'). The 24 questions are each asked twice: first to assess which values in the respondents' perceptions indicate the current situation, and second, which values would indicate the preferred situation (Appendix 1).

The validity of the scales has been demonstrated by Cameron and Quinn (1999, pp. 130-145). In previous studies conducted in 334 institutions of higher education, they identified substantive relationships between constituent parts of the four organisational values and observed plausible relations of the four values with external criteria, being the domain of effectiveness in which the organisation excelled and the decision strategy employed. For example, institutions with human relations culture were more effective in domains of morale or supportiveness and their decision strategies were characterised by high cohesion and collegiality. In a separate study, Howard (1998) too validated the competing values model. Cameron and Quinn (1999, p.139) also observed sufficient reliability: Cronbach's $\alpha$ coefficients were all above 0.70 . The instrument has not been revalidated for the 266 respondents in the current study but the $\alpha$ coefficients were found to demonstrate sufficient internal consistency per scale for both the current and preferred situation, all $\alpha$ coefficients being higher than 0.70 .

\section{Analysis}

A cultural profile score for each organisation was obtained by assessing the respondents' rating on the four organisational value scales. For presentation of the overall average across departments, the following parameters were calculated: total number of respondents $(N)$ and for each of the variables the mean score, $95 \%$ confidence interval, range and standard deviation. Furthermore, per scale a one-way analysis of variance (ANOVA) was performed, with the department as the random factor and the variance among respondents within a department as the error. 


\section{Methodological limitations}

The main limitation of this study concerns the limited number of participating departments and the low response rate for some departments. A second limitation is the limited number of departments per discipline (sector). The inclusion of more departments per discipline would have enabled us to investigate the influence of the discipline on organisational values. Cameron and Quinn might identify a third limitation, namely the decision to adopt the Likert scale to assess organisational values rather than the ranking method. Hence, the profiles of the departments in the four models of organisational values are less sharply defined. Conversely, pilot survey findings reveal that respondents believe the rating method enables them to express their perceptions and preferences more precisely.

\section{Results}

\section{Organisational values}

The first research question concerned the current organisational values, which are perceived as indicative for a respondent's department. In the overall analyses, the means of the four organisational values were all rather close to the neutral value of 3: HR (3.05), OS (3.16), RG (2.96) and IP (2.81) on a scale of 1-5 (Table 2 and Figure 2 ). The corresponding standard deviations were: $0.79,0.80,0.72$ and 0.70 respectively. These results indicate that the four values were only moderately experienced in the current situation. Furthermore, flexibility-oriented values like commitment, participation, innovation and growth seem to be met slightly more than controloriented values like achievement, putting high demands, conforming to formal rules and efficiency. 
Table 2. The four organisational values, current situation, preferred situation and differences C-P

\begin{tabular}{|c|c|c|c|c|c|c|c|c|c|c|c|c|}
\hline & \multicolumn{12}{|c|}{ Overall: across departments } \\
\hline & \multicolumn{3}{|c|}{$\begin{array}{l}\text { Human Relations } \\
\text { model (HR) }\end{array}$} & \multicolumn{3}{|c|}{$\begin{array}{l}\text { Open System model } \\
\text { (OS) }\end{array}$} & \multicolumn{3}{|c|}{$\begin{array}{l}\text { Rational Goal Model } \\
\text { (RG) }\end{array}$} & \multicolumn{3}{|c|}{$\begin{array}{l}\text { Internal Process } \\
\text { Model (IP) }\end{array}$} \\
\hline & $\mathrm{C}$ & $\mathrm{P}$ & C-P & $\mathrm{C}$ & $P$ & $C-P$ & $\mathrm{C}$ & $P$ & C-P & $\mathrm{C}$ & $P$ & C-P \\
\hline Mean & 3.05 & 4.15 & $-1.09 *$ & 3.16 & 3.96 & $-0.80 *$ & 2.96 & 3.26 & $-0.30 *$ & 2.81 & 3.42 & $-0.62 *$ \\
\hline$S D$ & 0.79 & 0.45 & 0.81 & 0.80 & 0.49 & 0.79 & 0.72 & 0.62 & 0.73 & 0.70 & 0.55 & 0.79 \\
\hline $95 \% \mathrm{Cl}$ low & 2.97 & 4.09 & -1.18 & 3.08 & 3.89 & -0.89 & 2.87 & 3.19 & -0.39 & 2.73 & 3.35 & -0.71 \\
\hline 95\% Cl High & 3.14 & 4.20 & -1.00 & 3.25 & 4.02 & -0.71 & 3.05 & 3.33 & -0.21 & 2.89 & 3.49 & -0.53 \\
\hline Min & 1.00 & 1.33 & -3.50 & 1.00 & 1.67 & -3.00 & 1.00 & 1.33 & -2.50 & 1.00 & 1.83 & -2.67 \\
\hline Max & 4.83 & 5.00 & 0.83 & 5.00 & 5.00 & 2.17 & 5.00 & 5.00 & 2.67 & 5.00 & 5.00 & 2.83 \\
\hline$N$ & 264 & 264 & 263 & 265 & 264 & 264 & 266 & 264 & 264 & 265 & 263 & 263 \\
\hline
\end{tabular}

Notes: 1 , strongly disagree; 5 , strongly agree; C, current; D, preferred; Difference C-P, current minus preferred (mean score of individual differences); $\mathrm{Cl}$, confidence Interval.

*) Statistically significant: $p \leq .003$

The second research question dealt with the preferred values. The overall means were HR (4.15), OS (3.96), RG (3.26) and IP (3.42) (Table 2 and Figure 2). The standard deviations were $0.45,0.49,0.62$ and 0.55 respectively, indicating considerably less variation, compared to the ratings of the current situation. The means show clear differences as to the desirability of the four organisational values. HR scored the highest, followed by OS and IP. RG scored the lowest, echoing the findings of Cameron \& Quinn (1999). The respondents clearly preferred the flexibility-oriented value models HR and OS (Figure 2) to the control-oriented value models RG and IP. In addition, the respondents preferred the internally-oriented value model HR more than the externally-oriented value model OS.

The third research question focussed on the differences between current and preferred. To determine an overall systematic difference (if any) between $C$ and $P$, the statistical significance of the mean difference C-P was assessed. For all four organisational values, the current-score was overall lower than the preferred-score; the level of difference varied per organisational value. The overall mean $\mathrm{C}-\mathrm{P}$ rates of HR, OS, RG and IP were as follows: $-1.09,-0.80,-0.30$ and -0.62 (Table 2 and Figure 2). The mean (overall) difference rates in all cases differed significantly from 0 . These results indicate that all organisational values gave rise to a sense of dissatisfaction among respondents. This dissatisfaction was larger for the flexibilityoriented values (HR and OS) than for the control-oriented values (RG and IP). Ten items (shown in italics in Appendix 1) showed marked differences between current and preferred scores. Six of these 10 items belong to HR, three to OS and one to IP. 


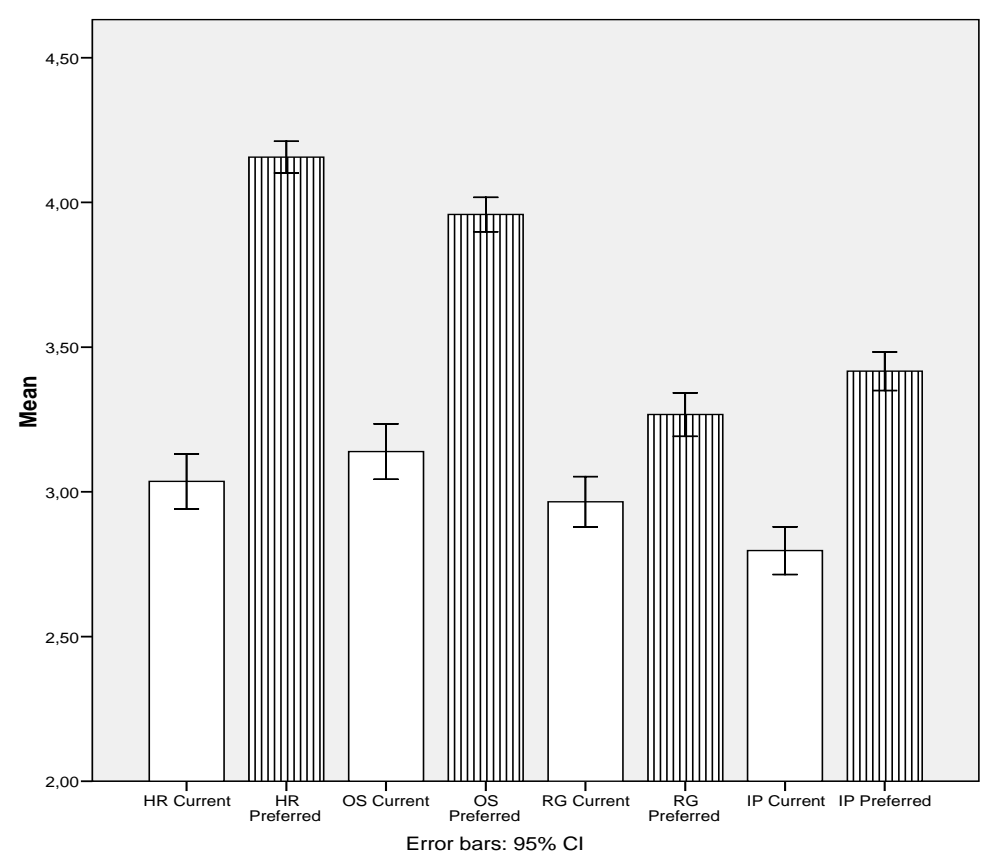

Figure 2. The four organisational values: perceived values current situation and preferred values

What does this mean for department policy? On the one hand, departments should pay much more attention to human relations values such as commitment, participation and development of human resources and to open system values like flexibility, readiness to change, innovation and growth. On the other hand, staff members are more focussed on internal than on external topics and developments. The gap between current and preferred is larger for teamwork and human development (HR) than for innovation and risk taking (OS), larger for internal coordination and efficiency (IP) than for competitiveness, result orientation and achievement (RD). Still some work has to be done to enhance external orientation.

\section{Variation across departments}

The fourth research question examined the variation, over the departments, in: the perception of the current situation; the indicated preferred situation; and the differences between current and preferred. Per variable, a one-way ANOVA was performed, with the department as the random factor and the variance among respondents within a department as the error. To determine the systematic differences (if any) between the departments, the corresponding variance and its significance were obtained. In addition, the error variance was calculated as an indicator of the (the lack of) similarity between respondents within a department. The square root 
of these variance components (that is, corresponding standard deviation) was calculated to gauge the level of variation rated on the five-point scale.

The means of the departments regarding the perception of the four organisational values in the current situation differ substantially from each other (Appendix 2): HR between 2.35 and 3.95; OS between 2.21 and 4.05; RG between 2.53 and 3.54, and IP between 2.08 and 3.26. The variation between the departments was found to be significant $(p \leq 0.003)$ for all value models in the current situation, with corresponding standard deviations ranging from 0.22 to 0.42 . The variation within the departments (error variations) was greater than the variation between the departments. However, by aggregating individual scores within the departments to means, it was possible to determine reliably the differences between the departments (see Appendix 2). The results indicate that, in general, the departments differed considerably with regard to the perceived organisational values of the four models for the current situation. According to staff members, some departments really succeeded in realising organisational values, other departments clearly failed.

With the exception of the organisational value RG, the departments had similar scores for the preferred situation (Appendix 2). For HR, the means of the departments in the preferred situation varied from 3.81 to 4.42 , for OS from 3.65 to 4.30 . For RG it ranged from 2.51 to 3.78 and for IP from 3.02 to 3.62 . The variation between the departments for the preferred values was only significant for HR and RG ( $p \leq 0.003$ ), with the corresponding standard deviation equalling 0.13 for HR and 0.27 for RD. Notably, the variations within the departments (error variations) were smaller for preferred than for current. There appears to be more agreement among the respondents of the same department for preferred than for current. It can be concluded that staff in universities of applied sciences share the same organisational values, regardless of whether their departments succeed or fail in putting these values into practice. In all departments, except one, HR values were preferred most. OS values are always more preferred than RG and IP values. Respondents of most departments preferred IP values to RG values but in some departments RG values were preferred.

In contrast with preferred, the differences between current and preferred for the four organisational values varied significantly over departments (Appendix 2). C-P for HR ranged from -0.55 to -1.93 , for OS from -0.27 to -1.48 , for RG from +0.32 to -1.03 and for IP from -0.01 to -1.55 . There were also positive differences for RG: the current situation for some departments scored higher than the preferred situation, indicating that RG values might be settled satisfactorily or even be pushed too far. The corresponding standard deviations over the departments were $0.37,0.30,0.29$ and 0.32 for $H R, O S, R G$ and IP respectively and were significant for each of the four organisational values $(p \leq 0.003)$. Here too, the variations within the departments were greater than those between the departments. 
Each department had its own distinct profile of organisational values: perception of the current situation, preferred values for the desired situation and differences between current and preferred. This is shown in Appendix 2 for all departments. A few examples: Department 5 (sector health) scored high with regard to the current situation in OS. The scores for HR and RG were neutral and IP was low. The greatest difference between current and preferred can be seen in IP. The scores of Department 6 (also health) for current were high in HR and OS and neutral in RG and IP. There were minor differences between the current and the preferred situation, indicating that the staff of Department 6 were relatively content with the current situation. Department 15 (engineering) scored neutral on all scales with regard to the current situation. Differences were greatest in HR and OS. Department 18 (arts) scored slightly above average on $\mathrm{HR}$ and OS with regard to the current situation and well above average in RG and IP. Here, the greatest differences were seen in HR and OS. Figure 3 represents the profiles of these departments.

Studies of Becher and Trowler (2001), Van Hout (1996) and Smart et al. (2000) indicate that organisational values not only vary per department but also per discipline. However, in the current study it was not possible to investigate reliably differences between disciplines or sectors because of low numbers of departments for some of the disciplines. Nevertheless, some trends have been observed that need further investigation. For example, in the current situation the health care departments scored relatively highly on the more flexibility-oriented values (HR and OS) but their scores on the internal process-values did not surpass average, which is opposed to what could be expected from the nature of their discipline. For the preferred situation, economics and business administration departments seemed to score highly on RG values. 

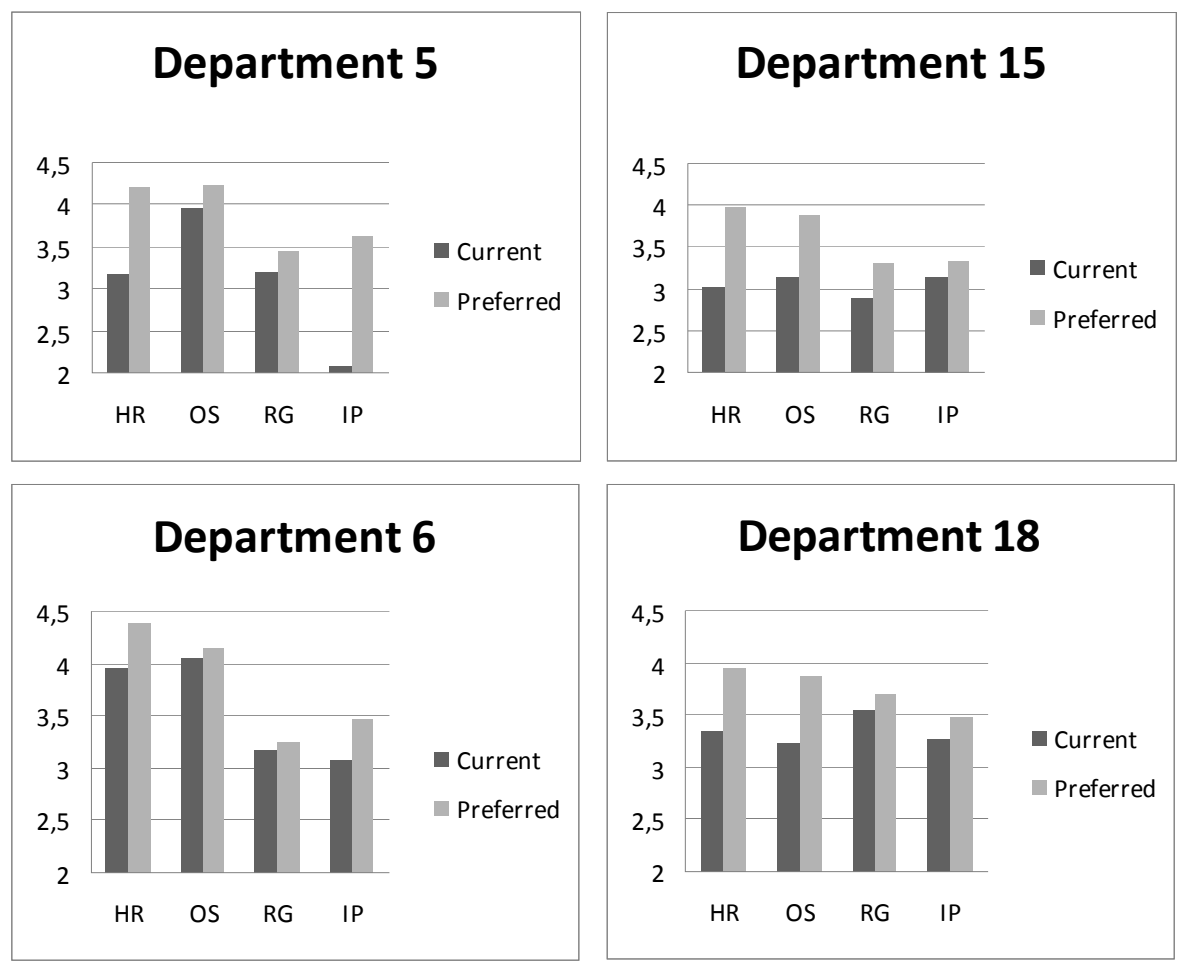

Figure 3. Organisational value profiles of four departments

\section{Conclusions}

The results of this research show that, overall, the four organisational values are moderately experienced in practice. The mean scores of the current values are closely clustered near the neutral level. There are, however, clear differences as to the desirability of the four values. Overall, the flexibility-oriented HR and OS values are more preferred then the control-oriented IP and RG values. For all four values, the overall differences between current and preferred indicate dissatisfaction. In addition, there is little variation over the departments as to the preferred values but the current values and the differences between current and preferred vary significantly and considerably over departments.

When these results are compared to the theoretical framework of Cameron and Quinn (1999), it can be concluded that their organisational values are recognisable in higher education. It is also clear that the distinction they make between the measurement of values in the current and preferred situations is justified. It creates an insight into the organisational values that require improvement in the depart- 
ments. This research demonstrates that departments that score highly in one of the organisational values are also likely to score highly in others. These findings are in accordance with the claims of Quinn et al. (1996) and Reitsma (2003, p. 19) who advocate an 'and-and' approach, seeking a balance between the values of all four models. Combining factors from all four competing models maximises the chances of success. This does not alter the fact that the four models of organisational values contain an element of competition.

This research offers suitable reference points for practice in higher education. Elements of the HR and OS models (competency development, external orientation, entrepreneurship, innovation, adaptability) have become prominent strategic issues in higher education (Ministry of Education, Culture and Science, 2007, pp. 8-10). Nevertheless, there remains a substantial gap between the respondents' perceived values (the current situation) and their preferred values (preferred situation). Furthermore, the results indicate that there are no great variations between departments regarding the preferred values and that these values may not be very liable to change. Current values, however, vary substantially over departments and might be susceptible of structural/managerial influences. Therefore, improvements are possible: greater focus on cultivating a culture of vulnerability, supervising and stimulating, staff development and teamwork, consensus and participation (HR); greater emphasis on dynamic entrepreneurship, risk-taking, innovation, distinctive capabilities and being at the vanguard of development (OS); greater emphasis on organisation, coordination and efficiency (IP).

In subsequent research, it would be worthwhile to examine the relationships between, on the one hand, the preferred organisational values and the views on quality that prevail within higher-education staff and, on the other hand, the perceptions of organisational values (current situation) in departments and the state of affairs in the area of quality assurance. Which characteristics make departments liable to introducing and embedding a real quality culture? Lastly, it would be a challenge to relate the findings of this research to the assessed quality of the departments according to accreditations and nationwide league tables.

\section{References}

Ahaus, K., 2006, 'Kwaliteit uit Waardering' ['Quality through Appraisal']. Inaugural address held at the Faculty of Management and Organisation of the University of Groningen on acceptance of his appointment to the endowed chair of Quality Management at the Management Science department, Groningen, The Netherlands, 4 April.

Becher, T. \& Trowler, P., 2001, Academic Tribes and Territories: Intellectual enquiry and the Cultures of Discipline, $2^{\text {nd }}$ edn. (Buckingham, Open University Press).

Berger, J.B. \& Milem, J.F., 2000, 'Organizational behavior and student outcomes', in: Smart, J.C. \& Tierny, W.G. (Eds.) Higher Education: handbook of theory and research, (vol. 15) (New York, Agathon Press). 
Bilsky, D. \& Jehn, K.A., 2002, ‘Organisationskultur und individuelle Werte. Belege für eine gemeinsame Struktur' [Organisational culture and individual values: evidence for a common structure], in Myrtek M. (Ed.), Die Person im biologischen und sozialen Kontext (Göttingen, Hogrefe).

Brennan, J., \& Shah, T., 2000, 'Quality assessment and institutional change: Experiences from 14 countries', Higher Education 40, pp. 331-49.

Cameron, Kim, S. \& Quinn, Robert E., 1999, Diagnosing and Changing Organizational Culture. Based on the Competing Values Framework (Reading, MA, Addison-Wesley).

European University Association (EUA), 2006, Quality culture in European universities: a bottom-up approach, report on the three rounds of the Quality Culture Project 2002-2006 (Brussels, EUA).

Harvey, L., \& Green, D., 1993, 'Defining quality', Assessment \& Evaluation In Higher Education, 18 (1), pp. 9-34.

Harvey, L., \& Newton, J., 2004, 'Transforming quality evaluation', Quality in Higher Education, 10(2), pp. 149-65.

HBO-raad, 2009a, The Netherlands Association of Universities of Applied Sciences. Avaliable at: www.hbo-raad.nl/english (accessed18 june 2009).

HBO-raad, 2009b, Feiten en cijfers, personeel in het hoger beroepsonderwijs [Factsheet, employment in Universities of Applied Sciences] (Den Haag, HBO-Raad).

Hitlin, S., \& Piliavin, J.A., 2004, 'Values: reviving a dormant concept', Annual Review of Sociology, 3, pp. 359-93.

Hofstede, G, 2001, Culture's Consequences: Comparing Values, Behaviors, Institutions and Organizations across Nations, $2^{\text {nd }}$ edn. (Thousand Oaks, Ca, Sage).

Howard, G., 1998, 'Validating the competing values model as a representation of organizational cultures', International Journal of Organizational Analysis, 6(3): pp. 231-50.

Jouslin de Noray, B., 2004, 'Theory and techniques on breakthrough change', proceedings of the 48th Congress of the European Organisation for Quality, Moscow, September.

Kezar, A. \& Eckel, P., 2002, 'The effect of institutional culture on change strategies in higher education', Higher Education, 73(4), 435-60.

Lysons, A., Hatherly, D. \& Mitchell, D.A., 1998, 'Comparison of measures of organisational effectiveness in U.K. higher education', Higher Education, 36(1), pp. 1-19.

Ministry of Education, Culture and Science, 2007, Strategische Agenda voor het Hoger Onderwijs-, Onderzoek -en Wetenschapsbeleid (Den Haag). [Strategic Agenda for Higher Education, Research and Science Policy] (The Hague, Ministry of Education, Culture and Science).

Newton, J., 2000, 'Feeding the beast or improving quality?: Academics'perceptions of quality assurance and quality monitoring', Quality in Higher Education, 6 (2), pp. 153-63.

Newton, J., 2001, 'Views from below: Academics coping with Quality', keynote presentation at the 6th QHE Seminar, Birmingham, UK, 26th May.

Perellon, J.F., 2007, 'Analysing quality assurance in higher education: proposals for a conceptual framework and methodological implications', in Westerheijden, D.F., Stensaker B. \& Rosa. M.J.. (Eds.) Quality Assurance in Higher Education. Trends in regulation, translation and transformation (Dordrecht, The Netherlands, Springer).

Pirsig, R.M., 1974, Zen and the Art of Motorcycle Maintenance: An inquiry into values (New York, Bantam Book).

Quinn, R. E., Faerman, S. R., Thompson, M. P. \& McGrath, M.R., 1996, Becoming a Master Manager: A Competency Framework, $2^{\text {nd }}$ edn. (New York, Wiley).

Quinn, R.E.,\& Rohrbaugh, J., 1983, 'A spatial model of effectiveness criteria: Towards a competing values approach to organizational analysis', Management Science, 29(3), pp. 363-77.

Reitsma, A.., 2003, Kritische Succesfactoren bij Visitatie en Kwaliteitsverbetering van P\&A-opleidingen: Casestudy-onderzoek (proefschrift) [Critical Success Factors in Visitation and Quality Improvement of Personnel Management Programmes: A case-based research approach (PhD-thesis)] (Heerlen, The Netherlands, Open Universiteit). 
Schwartz, S.H., 1992, 'Universals in the content and structure of values: Theoretical advances and empirical tests in 20 countries'. in Zanna, M. (Ed.), Advances in Experimental Social Psychology (vol. 25) (New York, Academic Press).

Schwartz, S.H. \& Bardi, A., 2001, 'Value hierarchies across cultures: Taking a similarities perspective', Journal of Cross-Cultural Psychology 32 (3), 268-90.

Schwartz, S.H. \& Bilsky, W., 1987, 'Toward a psychological structure of human values', Journal of Personality and Social Psychology, 53, pp. 550-62.

Sitkin, S.B., Sutcliffe, K.M. \& Schroeder, R.G., 1994, 'Distinguishing control from learning in Total Quality Management: A contingency perspective', Academy of Management review, 18(3), pp. 537-64.

Smart, J.C., Feldman, K.A. \& C.A. Ethington, 2000, Academic Disciplines. Holland's theory and the study of college students and faculty, $1^{\text {st }}$ Edn. (Nashville, TN, Vanderbilt University Press).

Stensaker, B., The Transformation of Organisational Identities, Interpretations of policies concerning the Quality of Teaching and Learning in Norwegian Higher Education (Enschede, The Netherlands, CHEPS, UT, 2004)

Stensaker, B., 2007, 'Quality as fashion: exploring the translation of a management idea into higher education', in Westerheijden, D.F., Stensaker B. \& Rosa, M.J. (Eds.) Quality Assurance in Higher Education. Trends in Regulation, Translation and Transformation (Dordrecht, The Netherlands, Springer).

Van der Zee, C., 1990, 'Kwaliteitsverbetering en innovatiemanagement' [Quality improvement and innovation management], Management en Organisatie, 44 (3), pp. 201-14.

Van Hout, J., 1996, Verschillen tussen Wetenschapsgebieden: Een structureel kenmerk van de universiteit [Differences between Scientific Disciplines: A structural characteristic of the university], Inaugural address at Amsterdam University, 14 March (The Hague, VUGA).

Van Hout, J., 2006, 'Kwaliteitszorg in het HO: nog veel werk aan de winkel' [Quality management in higher education: a lot remains to be done], in Van Hout, J., Ten Dam, G., Mirande, M., Terlouw, C. \& Willems J. (Eds.) Vernieuwing in het Hoger Onderwijs. Onderwijskundig handboek [Innovations in Higher Education. Handbook of education] (Assen, The Netherlands, Van Gorcum).

Van Kemenade, E, Pupius, M. \& Hardjono, T.D., 2008, 'More value to defining quality', Quality in Higher Education, 14(2), pp. 175-85.

Westerheijden, D.F., Hulpiau, V. \& Waeytens, K., 2007, 'From design and implementation to impact of quality assurance: An overview of some studies into what impacts improvement', Tertiary Education and Management, 13(4), 295-16.

Wetenschappelijke Raad voor het Regeringsbeleid, 2004, Bewijzen van Goede Dienstverlening [Evidence of Service Excellence] (Amsterdam, University Press).

Zbaracki, M.J., 1998, 'The Rhetoric and reality of Total Quality Management', Administrative Science Quarterly, 43, pp. 602-36. 


\section{Appendix 1. Questions from the OCAI}

\section{To what extent do you agree/disagree with the following statements?}

$A$ in the current situation of your department?

B in the preferred situation of your department?

The answers in both cases are:

\section{Strongly disagree 12345 Strongly agree}

\section{OCAI (Cameron \& Quinn, 1999).}

\section{Current}

Preferred

Difference

The questionnaire was translated in Dutch.

\begin{tabular}{|c|c|c|c|c|c|c|c|}
\hline & Mean & $S D$ & $N$ & Mean & $S D$ & $N$ & \\
\hline \multicolumn{8}{|l|}{ Human Relations Model (HR) } \\
\hline $\begin{array}{l}10 \text { The organization is a very personal place. It is like } \\
\text { an extended family. People seem to share a lot of } \\
\text { themselves. }\end{array}$ & 2.99 & 1.06 & 264 & 4.24 & 0.66 & 263 & -1.25 \\
\hline $\begin{array}{l}14 \text { The leadership in the organization is generally } \\
\text { considered to exemplify mentoring, facilitating or } \\
\text { nurturing. }\end{array}$ & 2.90 & 1.03 & 261 & 4.19 & 0.66 & 259 & -1.29 \\
\hline $\begin{array}{l}18 \text { The management style in the organization is char- } \\
\text { acterized by teamwork, consensus and participation. }\end{array}$ & 3.04 & 1.05 & 261 & 4.15 & 0.63 & 259 & -1.11 \\
\hline $\begin{array}{l}22 \text { The glue that holds the organization together is } \\
\text { loyalty and mutual trust. Commitment to this organi- } \\
\text { zation runs high. }\end{array}$ & 3.17 & 1.14 & 262 & 4.16 & 0.67 & 262 & -0.99 \\
\hline $\begin{array}{l}26 \text { The organization emphasizes human development. } \\
\text { High trust, openness, and participation persist. }\end{array}$ & 3.08 & 1.01 & 262 & 4.22 & 0.62 & 260 & -1.14 \\
\hline $\begin{array}{l}30 \text { The organization defines success on the basis of the } \\
\text { development of human resources, teamwork, em- } \\
\text { ployee commitment, and concern for people. }\end{array}$ & 3.07 & 1.08 & 257 & 3.98 & 0.73 & 255 & -0.91 \\
\hline \multicolumn{8}{|l|}{ Open System Model (OS) } \\
\hline $\begin{array}{l}11 \text { The organization is a very dynamic and entrepre- } \\
\text { neurial place. People are willing to stick their necks } \\
\text { out and take risks. }\end{array}$ & 3.16 & 1.08 & 263 & 4.11 & 0.64 & 263 & -0.95 \\
\hline $\begin{array}{l}15 \text { The leadership in the organization is generally } \\
\text { considered to exemplify entrepreneurship, innovating } \\
\text { or risk taking. }\end{array}$ & 3.12 & 1.00 & 257 & 3.90 & 0.73 & 256 & -0.78 \\
\hline $\begin{array}{l}19 \text { The management style in the organization is char- } \\
\text { acterized by individual risk-taking, innovation, free- } \\
\text { dom and uniqueness. }\end{array}$ & 2.82 & 1.02 & 260 & 3.72 & 0.83 & 258 & -0.90 \\
\hline $\begin{array}{l}23 \text { The glue that holds the organization together is } \\
\text { commitment to innovation and development. There is } \\
\text { an emphasis on being on the cutting edge. }\end{array}$ & 3.12 & 1.11 & 263 & 3.96 & 0.80 & 260 & -0.84 \\
\hline $\begin{array}{l}27 \text { The organization emphasizes acquiring new re- } \\
\text { sources and creating new challenges. Trying new } \\
\text { things and prospecting for opportunities are valued. }\end{array}$ & 3.36 & 1.09 & 262 & 4.07 & 0.65 & 260 & -0.71 \\
\hline $\begin{array}{l}31 \text { The organization defines success on the basis of } \\
\text { having the most unique or newest products. It is a } \\
\text { product leader and innovator. }\end{array}$ & 3.30 & 1.10 & 257 & 3.98 & 0.77 & 258 & -0.68 \\
\hline
\end{tabular}




\section{Appendix 1. (Continued)}

\section{Current}

Preferred

Difference

The questionnaire was translated in Dutch.

\begin{tabular}{|c|c|c|c|c|c|c|c|}
\hline & Mean & SD & $N$ & Mean & SD & $N$ & \\
\hline \multicolumn{8}{|l|}{ Rational Goal Model (RG) } \\
\hline $\begin{array}{l}12 \text { The organization is very results oriented. A major } \\
\text { concern is with getting the job done. People are very } \\
\text { competitive and achievement oriented. }\end{array}$ & 3.37 & 0.99 & 265 & 3.80 & 0.73 & 262 & -0.43 \\
\hline $\begin{array}{l}16 \text { The leadership in the organization is generally } \\
\text { considered to exemplify a no-nonsense, aggressive, } \\
\text { results-oriented focus. }\end{array}$ & 3.31 & 1.02 & 261 & 3.65 & 0.90 & 260 & -0.34 \\
\hline $\begin{array}{l}20 \text { The management style in the organization is char- } \\
\text { acterized by hard-driving competitiveness, high de- } \\
\text { mands, and achievement. }\end{array}$ & 2.52 & 1.08 & 261 & 2.59 & 0.99 & 261 & -0.07 \\
\hline $\begin{array}{l}24 \text { The glue that holds the organization together is the } \\
\text { emphasis on achievement and goal accomplishment. } \\
\text { Aggressiveness and winning are common themes. }\end{array}$ & 2.46 & 0.97 & 262 & 2.95 & 0.96 & 259 & -0.49 \\
\hline $\begin{array}{l}28 \text { The organization emphasizes competitive actions } \\
\text { and achievement. Hitting stretch targets and winning } \\
\text { in the marketplace are dominant. }\end{array}$ & 3.06 & 1.11 & 262 & 3.37 & 0.93 & 259 & -0.31 \\
\hline $\begin{array}{l}32 \text { The organization defines success on the basis of } \\
\text { winning in the marketplace and outpacing the compe- } \\
\text { tition. Competitive market leadership is key. }\end{array}$ & 3.09 & 1.09 & 256 & 3.21 & 0.98 & 255 & -0.12 \\
\hline
\end{tabular}

\begin{tabular}{|c|c|c|c|c|c|c|c|}
\hline \multicolumn{8}{|l|}{ Internal Process Model (IP) } \\
\hline $\begin{array}{l}13 \text { The organization is a very controlled and structured } \\
\text { place. Formal procedures generally govern what } \\
\text { people do. }\end{array}$ & 2.72 & 1.12 & 265 & 3.36 & 0.86 & 263 & -0.64 \\
\hline $\begin{array}{l}17 \text { The leadership in the organization is generally } \\
\text { considered to exemplify coordinating, organizing, or } \\
\text { smooth-running efficiency. }\end{array}$ & 2.90 & 1.06 & 262 & 3.99 & 0.74 & 260 & -1.09 \\
\hline $\begin{array}{l}21 \text { The management style in the organization is char- } \\
\text { acterized by security of employment, conformity, } \\
\text { predictability, and stability in relationships. }\end{array}$ & 2.75 & 0.99 & 260 & 3.12 & 0.93 & 259 & -0.37 \\
\hline $\begin{array}{l}25 \text { The glue that holds the organization together is } \\
\text { formal rules and policies. Maintaining a smooth- } \\
\text { running organization is important. }\end{array}$ & 2.67 & 0.98 & 261 & 3.10 & 0.86 & 260 & -0.43 \\
\hline $\begin{array}{l}29 \text { The organization emphasizes permanence and } \\
\text { stability. Efficiency, control and smooth operations are } \\
\text { important. }\end{array}$ & 2.91 & 0.98 & 261 & 3.57 & 0.80 & 260 & -0.66 \\
\hline $\begin{array}{l}33 \text { The organization defines success on the basis of } \\
\text { efficiency. Dependable delivery, smooth scheduling, } \\
\text { and low-cost production are critical. }\end{array}$ & 2.94 & 1.01 & 253 & 3.40 & 0.84 & 253 & -0.46 \\
\hline
\end{tabular}

Notes: Missing cases: $\min .1, \max 13 ;$ In italics: the ten items showing the greatest differences between current and preferred. 


\section{Appendix 2 The four organisational values: variation across departments}

\begin{tabular}{|c|c|c|c|c|c|c|c|c|c|c|c|c|c|}
\hline \multirow[b]{3}{*}{ Department } & \multirow[b]{3}{*}{$N$} & \multicolumn{9}{|c|}{ Mean per department } & & & \\
\hline & & \multicolumn{3}{|c|}{$\begin{array}{l}\text { Human Relations model } \\
\text { (HR) }\end{array}$} & \multicolumn{3}{|c|}{$\begin{array}{l}\text { Open System Model } \\
\text { (OS) }\end{array}$} & \multicolumn{3}{|c|}{$\begin{array}{l}\text { Rational Goal Model } \\
\text { (RG) }\end{array}$} & \multicolumn{3}{|c|}{$\begin{array}{l}\text { Internal Process Model } \\
\text { (IP) }\end{array}$} \\
\hline & & C & $\mathrm{P}$ & C-P & C & $\mathrm{P}$ & C-P & C & $\mathrm{P}$ & C-P & C & $\mathrm{P}$ & C-P \\
\hline 1 Econ & 10 & 2.88 & 4.13 & -1.25 & 2.68 & 3.90 & -1.22 & 2.75 & 3.78 & -1.03 & 3.15 & 3.41 & -0.27 \\
\hline 2 Econ & 18 & 3.04 & 4.21 & -1.16 & 3.31 & 4.09 & -0.77 & 3.15 & 3.68 & -0.53 & 2.69 & 3.39 & -0.70 \\
\hline 3 Health & 12 & 3.26 & 4.24 & -0.97 & 3.22 & 3.97 & -0.75 & 2.88 & 3.22 & -0.35 & 2.93 & 3.32 & -0.39 \\
\hline 4 Health & 11 & 3.70 & 4.25 & -0.55 & 3.37 & 3.91 & -0.54 & 2.76 & 2.51 & +0.26 & 3.01 & 3.02 & -0.01 \\
\hline 5 Health & 11 & 3.17 & 4.21 & -1.05 & 3.96 & 4.23 & -0.27 & 3.21 & 3.44 & -0.23 & 2.08 & 3.62 & -1.55 \\
\hline 6 Health & 22 & 3.95 & 4.39 & -0.45 & 4.05 & 4.14 & -0.09 & 3.18 & 3.25 & -0.07 & 3.07 & 3.46 & -0.47 \\
\hline 7 Health & 17 & 2.90 & 4.11 & -1.21 & 3.04 & 3.90 & -0.86 & 3.21 & 3.15 & +0.05 & 2.84 & 3.61 & -0.77 \\
\hline 8 Health & 17 & 3.08 & 3.97 & -0.89 & 2.74 & 3.84 & -1.10 & 2.79 & 3.34 & -0.55 & 2.80 & 3.57 & -0.77 \\
\hline 9 Educ & 16 & 2.84 & 4.40 & -1.51 & 3.42 & 4.10 & -0.68 & 3.11 & 3.13 & +0.06 & 3.03 & 3.43 & -0.40 \\
\hline 10 Educ & 11 & 2.89 & 4.26 & -1.36 & 3.15 & 3.99 & -0.85 & 3.26 & 2.95 & +0.32 & 2.73 & 3.55 & -0.82 \\
\hline 11 Educ & 13 & 3.06 & 4.06 & -1.01 & 3.02 & 3.82 & -0.79 & 2.67 & 3.17 & -0.50 & 3.06 & 3.52 & -0.45 \\
\hline 12 Soc & 10 & 2.35 & 3.81 & -1.46 & 2.21 & 3.65 & -1.44 & 2.53 & 2.81 & -0.28 & 2.34 & 3.28 & -0.94 \\
\hline 13 Soc & 31 & 2.35 & 4.28 & -1.93 & 2.48 & 3.96 & -1.48 & 2.72 & 3.10 & -0.38 & 2.52 & 3.26 & -0.74 \\
\hline 14 Soc & 10 & 3.47 & 4.02 & -0.55 & 3.08 & 3.93 & -0.85 & 2.62 & 3.48 & -0.87 & 3.08 & 3.38 & -0.30 \\
\hline 15 Engin & 14 & 3.02 & 3.99 & -0.96 & 3.15 & 3.89 & -0.74 & 2.90 & 3.31 & -0.40 & 3.15 & 3.33 & -0.18 \\
\hline 16Engin & 10 & 2.68 & 4.42 & -1.73 & 3.58 & 4.30 & -0.72 & 3.30 & 3.47 & -0.17 & 2.27 & 3.44 & -1.17 \\
\hline 17 Engin & 15 & 2.93 & 3.94 & -1.01 & 3.21 & 3.69 & -0.48 & 2.69 & 3.19 & -0.50 & 2.51 & 3.43 & -0.92 \\
\hline 18 Arts & 18 & 3.35 & 3.96 & -0.60 & 3.24 & 3.88 & -0.74 & 3.54 & 3.69 & -0.24 & 3.26 & 3.49 & -0.34 \\
\hline \multicolumn{14}{|c|}{ Overall mean and variance components } \\
\hline Overall Mean & 266 & 3.05 & 4.15 & $-1.09 *$ & 3.16 & 3.96 & $-0.80^{*}$ & 2.96 & 3.26 & $-0.30^{*}$ & 2.81 & 3.42 & $-0.62^{*}$ \\
\hline $\begin{array}{l}\text { Variance De- } \\
\text { partment }\end{array}$ & & $0.13^{*}$ & $0.02^{*}$ & $0.13^{*}$ & $0.18^{*}$ & 0.01 & $0.09 *$ & $0.05^{*}$ & $0.07 *$ & $0.09 *$ & $0.09 *$ & 0.00 & $0.10^{*}$ \\
\hline Variance Error & & 0.46 & 0.19 & 0.49 & 0.44 & 0.23 & 0.52 & 0.48 & 0.33 & 0.47 & 0.42 & 0.30 & 0.54 \\
\hline SD department & & $0.36^{*}$ & $0.13^{*}$ & $0.37^{*}$ & $0.42^{*}$ & 0.10 & $0.30^{*}$ & $0.22^{*}$ & $0.27^{*}$ & $0.29 *$ & $0.29 *$ & 0.00 & $0.32^{*}$ \\
\hline \multicolumn{14}{|l|}{$\begin{array}{l}\text { Sqrt (Variance } \\
\text { Department) }\end{array}$} \\
\hline SD Error: & & 0.68 & 0.43 & 0.70 & 0.67 & 0.48 & 0.72 & 0.69 & 0.57 & 0.68 & 0.64 & 0.55 & 0.74 \\
\hline $\begin{array}{l}\text { Sqrt (Variance } \\
\text { Error) }\end{array}$ & & & & & & & & & & & & & \\
\hline
\end{tabular}

Notes: 1 , strongly disagree; 5 : strongly agree; $C$, current; $P$, preferred; Difference $C-P$, current minus preferred (mean score of individual differences).

*) Statistically significant: $p \leq .003$ 


\section{CHAPTER 4}

\section{Teachers' conceptions of quality and organisational values in higher education: Compliance or Enhancement? ${ }^{2}$}

\footnotetext{
${ }^{2}$ Published as: Kleijnen, J., Dolmans, D., Willems, J., \& Van Hout, J. (2011). Teachers' conceptions of quality and organisational values in higher education: compliance or enhancement? Assessment \& Evaluation in Higher Education, DOI:10.1080/02602938.2011.611590. Available at: http://dx.doi.org/ 10.1080/02602938.2011.611590 (accessed 28 October 2011).
} 


\begin{abstract}
Teachers are often assumed to have a negative attitude towards quality endeavours of their institutions and to hold defensive organisational values. However, there is little empirical research on this issue. This study focuses on teachers' conceptions of quality, on their preferred organisational values and on the relationships between the two.

A written questionnaire was presented to the teaching staff from 18 departments of universities of applied sciences in the Netherlands $(\mathrm{N}=266)$. It comprised 18 questions about teachers' conceptions of quality, representing two quality scales: compliance and accountability and enhancement and improvement. A further 24 questions, related to organisational values, represent two scales that typify flexible organisations, and two that typify control-oriented organisations. The results reveal a neutral score on the compliance and accountability conceptions of quality and on the control-oriented organisational values, and a high score on enhancement and improvement and on the flexibility-oriented values. Both pairs appear to be moderately positively correlated. Despite the need for further qualitative research, it can be concluded that teachers perceive quality first and foremost as enhancement and improvement, rather than as compliance to external standards and accountability. These findings offer interesting perspectives for the further development of an internal quality culture in higher education.
\end{abstract}

Keywords: conceptions of quality; compliance and accountability; enhancement and improvement; organisational values 


\section{Introduction}

There is a debate in the literature about educational quality and quality culture in higher education. Institutions and departments are assumed to be more concerned about meeting basic standards, compliance and external accountability than about improvement and enhancement of teaching and learning (Sallis 2002; Harvey and Newton 2007). At the same time teaching staff often perceive quality management and the accessory cultural change as another bureaucratic checking device (Spencer-Matthews 2001; European University Association [EUA] 2010), often leading to 'ritualistic game-playing' with performance indicators and impression management (Newton 2002). This attitude reveals distrust. Teachers see quality as a negative buzzword (Spencer-Matthews 2001). After the 1990s and after Bologna, however, European universities shifted their interest from concern about public management ideas and conforming to them to a search for excellence (Harvey and Stensaker 2008). This might have affected staff's opinions but so far teachers' conceptions about quality have been hardly investigated. Insight into teachers' conceptions and the values they hold is important for the development of a quality culture in higher education. Is meeting basic standards really the main quality concern of teaching staff (Sallis 2002)?

Defining quality is an intricate endeavour. Harvey and Green $(1993,10-11)$ call quality "a slippery concept", "no easier even to describe and discuss than deliver in practice" (after Gibson 1986). The definition may vary according to the interests and priorities of the different stakeholders and in different situations. What do they think, are the purposes of the university? What are the right things of the university to do to achieve these purposes and the right ways of doing them (Gibson 1986; Houston 2008)? Therefore literature traces a variety of definitions of the quality concept (Harvey and Green 1993; EUA 2006). This paper confines itself to the conceptions and values of one of the most important stakeholder groups in higher education, being the teaching staff. What conceptions of quality do they really have and which values do they prefer for the desired situation of their teaching departments?

Despite the complexity of the quality concept, many authors separate teachers' conceptions of quality into two broad categories according to their main focus on either the compliance and accountability process or the process of enhancement and improvement (Harvey and Green 1993; Sallis 2002; Watty 2006; EuA 2006; Harvey and Newton 2007; Lomas 2007; Findlow 2008; Houston 2008; Brundrett and Rhodes 2011). These conceptions refer to different approaches within educational practice. For example, Harvey and Green $(1993,10)$, in spite of describing themselves a manifold of definitions of quality, identify a first conception of quality as self-evident or based on more or less absolute thresholds "that have to be exceeded to obtain a quality rating". These thresholds may be professional or academic criteria that are generally accepted and applicable, either to guarantee realization of 
minimal (basic) standards or to exceed very high standards and attain excellence. The emphasis of this conception is on compliance with standards and external accountability. Next to it they identify a second conception, which "is relative to the 'processes that result in the desired outcomes" (Harvey and Green 1993, 10). In this view, quality is based on the ability of an institution to fulfil the requirements, needs or wishes of the student or the professional work environment and on the capability of programmes of study to fulfil their aims. The focus is not in the first place on whether formulated objectives can be attained as effectively as possible but on whether transformation can be achieved and a qualitative change can be effected. For example, the programme raises the students' qualities to a higher level and enhances their competencies. According to Harvey and Newton (2007) the two conceptions compliance to standards and accountability on the one hand and enhancement and improvement on the other hand are not "two ends of a single continuum". They are "two distinct and only partly related dimensions". In some situations compliance may lead to improvement, in others it may not (Harvey and Newton 2007, 232).

Sallis (2002) is another example of making a distinction between two types of conceptions of quality. Firstly, he identifies procedural quality, with its key descriptors of quality proving, approving and reporting of products and service standards. Secondly, he identifies transformational quality, which focuses on the customer: "improving more than proving", "exceeding customers' expectations". According to Sallis (2002), higher education reached a turning point in the 1990s. He wrote in 1996: "Unfortunately, too much of the debate is about league tables and inspection regimes, and there is still too little discussion about the tools and techniques that can be used to improve and enhance the quality provision" (Sallis 1996, VII). However, in the 2002 edition, he warily states that many people engaged in higher education believe they are part of the quality movement (Sallis 2002, VI).

A third and final example of this distinction between two conceptions of quality is presented in the final report of the Quality Culture Project of the European University Association (EUA 2006). The project comprised a detailed investigation into the quality culture in 134 European universities. The report starts with a list of nine quality definitions. Gradually, project participants came to see ample evidence for two quality approaches. One approach is called a standards-based approach. This approach is aimed at ensuring compliance with external standards. The second approach runs contrary to the first: it focuses primarily on the processes of development, implementation and improvement. "Quality is an on-going exercise; it is not a state that is reached once and for all but one that needs to be pursued continuously" (EUA 2006, 10).

According to literature, the conceptions of quality are embedded in the culture of an institution (Harvey and Green 1993; Cameron and Quinn 1999; Kezar and Eckel 2002; Lomas 2004; EUA 2006). They may be affected by teachers' positions 
and interests and by the values they regard as important for the preferred situation of their teaching departments. Values are a core element of culture (Hofstede 2001), which is shared, learned and symbolic (Harvey and Stensaker 2008). They are desirable, motivational goals that transcend any situation and guiding principles for people's lives (Hitlin, Piliavin 2004) but they do not influence action directly. There often is a huge gap between what people think, the values they prefer, their ideology on the one hand and what they actually do, the values they put into practice on the other (Brunsson 1989; Argyris 1990; Cartwright 2007 Berings 2009; Kleijnen et al. 2009). Values that are widely preferred are often blocked by defence mechanisms and structural barriers like lack of trust, faulty communication channels, large hierarchical distances or financial constraints (Harvey 2006; Mundet Hiern et al. 2006; EUA 2010). Nevertheless these preferred values may indicate what teaching staff consider really important for their department.

To measure and examine organisational values, this paper adopts the 'competing values framework' of Cameron and Quinn (1999) and Quinn et al. (2007). This framework is built on a theoretical basis and has been amply validated. It links up with a long tradition of organisational theory, such as Taylor's theory of scientific management, Weber's theory of bureaucratic structure, McGregor's human relations (HR) theory and the open system (OS) or contingency theory which arose between 1950 and 1975 (Patterson et al. 2005; Quinn et al. 2007). In addition, it results in an instrument that can assess experiences of all employees in relation to the organisational unit they are working in (Patterson et al. 2005). The framework is a two-dimensional model. The first dimension is related to competition between internal and external orientations, the second deals with the tension between control and flexibility. These dimensions are well applicable to the education domain. Recently similar dimensions were also used by, Harvey and Stensaker (2008) and Brundrett and Rhodes (2011) in order to describe the possible variety in quality cultures. Apparently, the dimensions are considered to yield deeper understanding of the organisational culture.

The two dimensions, 'internal versus external orientation' and 'control versus flexibility' result in four quadrants, each quadrant representing an ideal type of values (Cameron and Quinn 1999). Thus the framework consists of two, controloriented value orientations: the Rational Goal model (RG) with an external focus and with its main values of profit and efficiency, goal setting and planning, and the Internal Process model (IP) with an internal focus and its main values of stability and control, measurement and information management. Control oriented organisations cherish their acquired traditions. They adopt strict rules and work methods and attach considerable importance to approved professional skills. In addition, the framework comprises two flexibility-oriented organisational values: the Human Relations model (HR) with an internal focus and with the main values of participation and involvement, cohesion and morale and the external Open System model 
(OS) with values such as growth and resource acquisition, flexibility and innovation. Flexibility oriented organisations create opportunities and take risks. They define professionalism as the ability to cope with new situations and challenges. These four types of values are not mutual exclusive and discrete. Actually, they are competing with one another. Each of them may be preferred by staff to a greater or less degree. The conception of quality as compliance to standards and accountability is expected to show a positive correlation with the control-oriented values. The conception of quality as enhancement and improvement is expected to correlate positively with the flexibility-oriented values (Cameron and Quinn 1999; Brundrett and Rhodes 2011).

Teachers have a pivotal position in higher education. They develop educational programmes, they deliver them and are responsible for assessment. What they think and do is crucial to the quality of higher education (Newton 2000; Cruickshank 2003). This study focuses on teachers' conceptions of quality and their preferred organisational values. Firstly, it investigates to what extent teachers perceive quality as compliance with standards and accountability or as enhancement and improvement Secondly, it investigates to what extent teachers prefer each of the four organisational values. In addition it investigates the relationship between teachers' conceptions of quality and their preferred organisational values.

\section{Methodology}

\section{Context and participants}

This study is based on a survey conducted at Universities of Applied Sciences (government-approved and state funded institutions offering professional bachelor and master degree programmes) in the Netherlands between March and September 2008. A total of thirty departments participated in the survey, of which all teaching staff members were asked to fill out a questionnaire. A total of 991 questionnaires were sent out; 316 (32\%) were returned. Eighteen departments had 10 or more respondents. This survey is limited to the 266 respondents from these 18 departments. The response rate of these 18 departments ranged from 18 to $63 \%$ per department.

The distribution of departments and respondents over scientific areas is shown in Table 1. Of the respondents 53\% were male and the median age was 48.2 years. The participants' highest academic qualifications were bachelor's degree (32.5\%), master's degree (59\%) and doctoral degree (4.5\%), while $4 \%$ did not provide this information. Sixty-five percent of the respondents had held a position within a university of applied sciences for more than six years and $85 \%$ were employed between $50 \%$ and full time. According to data published by the Council of the Universities of 
Applied Sciences (HBO-Raad 2009) the study sample appears to be representative with respect to age, gender and academic qualifications. The employment data suggest that the respondents have had sufficient experience within higher education to give well considered answers to the survey questions.

Table 1. Departments and respondents by scientific area

\begin{tabular}{lccc}
\hline Scientific area & Departments & Respondents & $\begin{array}{c}\text { \% of total number of } \\
\text { respondents }\end{array}$ \\
\hline Economics and Business Administration & 2 & 28 & 11 \\
Health Care & 6 & 90 & 34 \\
Education (teacher training) & 3 & 40 & 15 \\
Social Welfare & 3 & 51 & 19 \\
Engineering and Technology & 3 & 39 & 15 \\
Fine and Performing Arts & 1 & 18 & 7 \\
Total & 18 & 266 & $101^{\text {a }}$ \\
\hline
\end{tabular}

a) The percentages do not sum to 100 exactly due to rounding up.

\section{Instruments}

Today the various concepts of quality of Harvey and Green (1993) are widely referred to in literature (e.g. EUA 2006; Watty 2006; Lomas 2007; Harvey and Stensaker 2008; Houston 2008). These concepts encompass both the complexity of quality as well as the two conceptions or approaches of quality referred to in the introduction. On the basis of the various concepts 18 questions were formulated. Teachers were asked how much they agreed or disagreed that statements indicate educational quality. All questions had answer options on a five-point Likert scale, from 1 'fully disagree' to 5 'fully agree'. Exploratory factor analysis, using the principal components method with Varimax rotation (orthogonal), resulted in several possible factor solutions. However, the two factor solution yielded the best possibilities for interpretation and a match with the two conceptions of quality described. It allowed for the construction of two corresponding rating scales. Scale 1 measures the conception of quality as compliance and accountability and is based on nine items (Appendix 1). Quality is revealed in particular through compliance with basic or minimal criteria of accreditation and objective, measurable criteria, external accountability, high scores in national rankings and programme results, such as achieving envisaged objectives and high grades. The scale corresponds with the more or less absolute conceptions of quality (e.g. compliance with basic, minimum criteria) of Harvey and Green (1993), with the procedural quality of Sallis (2002) and compliance of the EUA (2006). Cronbach's $\alpha=0.66$. Scale 2 measures the conception of quality as enhancement and improvement and consists also of nine items (Appendix 1). This scale measures quality in terms of focusing on students who selfconsciously and critically shape their own development. The educational pro- 
gramme has been carefully put together, and is subject to constant improvement and development. It is tailored to the wishes of the students, and the programme prepares the students thoroughly for their future career. The scale corresponds with the relative, improvement-oriented vision on quality of Harvey and Green (1993), the transformational quality of Sallis (2002) and the improvement approach of the EUA (2006). Cronbach's $\alpha=0.76$. The two scales are not mutually independent; they show a moderate positive correlation with a medium effect size (Pearson's $r(264)=0.33, p \leq 0.000)$. Being two distinct scales they cannot be considered as the opposite ends of one continuum.

The organisational values were assessed using the Organizational Culture Assessment Instrument (Appendix 2) of Cameron and Quinn (1999). Teachers were asked to indicate on a five-point Likert scale how much they agreed or disagreed that value statements were desirable for their departments. The instrument comprises two control-oriented value scales (for the Rational Goal and the Internal Process model), and two flexibility-oriented value scales (for the Human Relations model and the Open System model). The validity of the scales has been demonstrated in various studies, conducted in 334 institutions of higher education. Cameron \& Quinn (1999, p. 140) observed plausible relations of the four values with external criteria, such as a decision strategy of cohesion and collegiality within institutions with a human relations culture. In separate studies, Howard (1998) and Patterson et al. (2005) too validated the instrument. Cameron \& Quinn $(1999,139)$ also observed sufficient reliability: Cronbach's $\alpha$ coefficients were all above 0.70. The instrument has not been revalidated for the 266 respondents in the current study, but the $\alpha$ coefficients were found to demonstrate sufficient internal consistency per scale, all $\alpha$ coefficients being higher than 0.70 .

\section{Analysis}

In order to answer the first two research questions, the following parameters were calculated: the number of respondents $(N)$, the mean scores on the scales, the standard error mean, the range and the standard deviation. A $t$-test was used to determine whether the differences between the average scale scores were significant, both overall and at the department level. The third research question, concerning the relationship between the two conceptions of quality and the four organisational values, was examined by computing Pearson's correlation coefficients.

\section{Results}

The mean score on the conception of quality as compliance and accountability is $M$ $=3.27(S D=0.50)$ and on enhancement and improvement is $M=4.14(S D=0.47)$ 
(Table 2). These scores differ significantly from each other. The paired $t$-test is: $t(265)=25.249, p \leq 0.000$ (table 3).

Table 2. Two conceptions of quality: number of respondents $(N)$, score range (minimum - maximum), mean statistic, standard error (SE), standard deviation (SD) and Cronbach's $\alpha$

\begin{tabular}{lccccccc}
\hline & $\mathbf{N}$ & Minimum & Maximum & Statistic & SE & SD & Cronbach's $\alpha$ \\
\hline $\begin{array}{l}\text { Compliance and } \\
\text { accountability } \\
\begin{array}{l}\text { Enhancement and } \\
\text { improvement }\end{array}\end{array}$ & 266 & 1.89 & 5.00 & 3.27 & .03 & .50 & 0.66 \\
\hline
\end{tabular}

a) Five point scale: $1=$ fully disagree; $5=$ fully agree; $3=$ neutral

Table 3. Paired samples $t$-test of differences between two conceptions of quality: mean, standard deviation $(S D)$, standard error $(S E)$, mean/SE $(t)$, degrees of freedom $(d f)$ and significance (Sig.) of paired differences

\begin{tabular}{|c|c|c|c|c|c|c|}
\hline \multirow[b]{2}{*}{ Pair } & \multicolumn{6}{|c|}{ Paired differences } \\
\hline & Mean & $S D$ & SE Mean & $t$ & $d f$ & Sig. (2-tailed) \\
\hline $\begin{array}{l}\text { Enhancement and im- } \\
\text { provement - (minus) } \\
\text { Compliance and account- } \\
\text { ability }\end{array}$ & 0.873 & 0.564 & 0.035 & 25.249 & 265 & 0.000 \\
\hline
\end{tabular}

This result demonstrates that teachers within higher education mainly perceive quality as an enrichment of the student's learning process and as improvement of the department and the academic processes. This conception of quality scores higher than compliance with basic, minimum criteria and other externally imposed criteria, external accountability and the desire to secure a prominent position in national rankings and league tables. Overall, teachers see quality more as a process of enhancement and improvement than as a compliance tool. This applies not only to the overall sample, but to all eighteen departments as well. The paired $t$-scores per department vary from $t(10)=3.120, p \leq 0.011$ to $t(30)=11.006, p \leq 0.000$.

The mean scores on the two preferred flexibility oriented organisational values are $M=4.15(S D=0.45)$ for the Human Relations $(\mathrm{HR})$ model and $M=3.96$ (SD = 0.49) for Open System (OS). The two control oriented values are $M=3.26$ (SD = 0.62 ) for Rational Goal (RG) and $M=3.42$ (SD=0.55) for Internal Process (IP) (Table 4). These scores of the flexibility oriented and the control oriented values differ significantly from each other. For HR - RG, $t(262)=20.516, p \leq 0.000$; for HR $-I P$, $t(262)=20.590, p \leq 0.000$; for OS - RG, $t(263)=18.636, p \leq 0.000$; and for OS - IP, $t(262)=13.926, p \leq 0.000$ (Table 5). Thus, at the overall level, teachers appear to prefer flexibility oriented values to control oriented values. At the level of departments the paired $t$-test is significant for the difference HR - RG within 17 out of 18 
departments, for HR - IP within all departments, for OS - RD within 16 and for OS IP within 15 out of 18 departments $(p<0.05)$.

Table 4. The four preferred organisational values: number of respondents $(N)$, score range (minimum maximum), mean statistic, standard error (SE) , standard deviation (SD) and Cronbach's $\alpha$

\begin{tabular}{|c|c|c|c|c|c|c|c|}
\hline \multirow[b]{2}{*}{ Values } & \multirow[b]{2}{*}{$N$} & \multirow[b]{2}{*}{ Minimum } & \multirow[b]{2}{*}{ Maximum } & \multicolumn{2}{|c|}{ Mean $^{\mathrm{a}}$} & \multicolumn{2}{|r|}{ Cronbach's } \\
\hline & & & & Statistic & $S E$ & $S D$ & $\alpha$ \\
\hline \multicolumn{8}{|c|}{ Flexibility oriented values } \\
\hline Human relations (HR) & 264 & 1.33 & 5.00 & 4.15 & 0.03 & 0.45 & 0.77 \\
\hline Open system OS) & 264 & 1.67 & 5.00 & 3.96 & 0.03 & 0.49 & 0.73 \\
\hline \multicolumn{8}{|l|}{ Control oriented values } \\
\hline Rational goal (RG) & 264 & 1.33 & 5.00 & 3.26 & 0.04 & 0.62 & 0.73 \\
\hline Internal process (IP) & 263 & 1.83 & 5.00 & 3.42 & 0.03 & 0.55 & 0.72 \\
\hline Valid N (listwise) & 263 & & & & & & \\
\hline
\end{tabular}

a) Five point scale: $1=$ fully disagree; $5=$ fully agree; $3=$ neutral

Table 5. Paired samples $t$-tests of differences between four preferred organisational values: mean, standard deviation $(S D)$, standard error $(S E)$, mean/SE $(t)$, degrees of freedom $(d f)$ and significance (Sig.) of paired differences

\begin{tabular}{lllcccc}
\hline & \multicolumn{5}{c}{ Paired differences } \\
\hline Pairs & Mean & SD & SE Mean & $\boldsymbol{t}$ & df & $\begin{array}{c}\text { Sig. } \\
\text { (2-tailed) }\end{array}$ \\
\hline Pair 1 Human Relations - (minus) Open System & 0.199 & 0.394 & 0.024 & 8.170 & 262 & 0.000 \\
Pair 2 Human Relations - Rational Goal & 0.890 & 0.703 & 0.043 & 20.516 & 262 & 0.000 \\
Pair 3 Human Relations - Internal Process & 0.740 & 0.58 & 0.036 & 20.590 & 262 & 0.000 \\
Pair 4 Open system - Rational Goal & 0.696 & 0.607 & 0.037 & 18.636 & 263 & 0.000 \\
Pair 5 Open System - Internal Process & 0.541 & 0.630 & 0.039 & 13.926 & 262 & 0.000 \\
Pair 6 Rational Goal - Internal Process & -0.150 & 0.636 & 0.039 & -3.814 & 262 & 0.000 \\
\hline
\end{tabular}

The third research question deals with the relationship between the two conceptions of quality and the four preferred organisational values. The control-oriented organisational values, Rational Goal (RG) and Internal Process (IP) show a weak to moderate correlation with the compliance and accountability conception of quality. The correlation for RG is Pearson's $r(262)=0.21$ and for IP $r(261)=0.27$. The preferred flexible organisational values, Human Relations (HR) and Open System (OS), show a moderate positive correlation, with medium size impact, with the enhancement and improvement conception of quality: for HR $r(262)=0.39$ and for OS $r(262)$ $=0.32$. In addition, there is a weak correlation between OS and compliance and accountability (Pearson's $r(262)=0.18, p \leq 0,01$ ). Pearson's $r$ is significant for all the aforementioned correlations: $p \leq 0,01$ (Table 6). 
Table 6. Pearson correlations between preferred organisational values and the two conceptions of quality

\begin{tabular}{llcc}
\hline & Values & $\begin{array}{c}\text { Compliance and } \\
\text { accountability }\end{array}$ & $\begin{array}{c}\text { Enhancement and } \\
\text { improvement }\end{array}$ \\
\hline Flexibility oriented & Human relations (HR) & $0.13^{*}$ & $0.39^{* *}$ \\
& Open system (OS) & $0.18^{* *}$ & $0.32^{* *}$ \\
Control oriented & Rational goal (RG) & $0.21^{* *}$ & 0.09 \\
& Internal process (IP) & $0.27^{* *}$ & $0.15^{*}$ \\
\hline
\end{tabular}

* Correlation is significant at the 0.05 level (2-tailed).

** Correlation is significant at the 0.01 level (2-tailed).

\section{Conclusions and discussion}

This study focuses firstly on two general conceptions of quality of teaching staff which may yield a substantial contribution to a better understanding of two different approaches of quality in educational practice. First of all, it can be concluded from this study that teachers perceive quality first and foremost as enhancement of the possibilities and opportunities of their students, and as improvement of the department, rather than as a compliance tool to satisfy standards and external accountability. This conclusion seems promising since some authors argue that departments are assumed to be more concerned about meeting basic standards, compliance and external accountability than about improvement and enhancement of teaching and learning (Sallis 2002; Harvey and Newton 2007). According to the findings of this study enhancement and improvement, is the core idea of quality, which is fully alive in the minds of the teaching staff, both overall and in all investigated departments. Compliance and accountability may fulfil necessary functions for the organisation but continuous improvement approves to be the key driver of quality (Huisman and Currie 2004; Harvey and Newton 2007). This fits in with the idea that without continuous improvement, 'compliance and accountability' will be reduced to "feeding the beast" of bureaucracy (Newton 2000, 153). While the negative connotations of quality in the literature, referred to in the introduction (buzzword, lack of trust in professionals, bureaucracy), and the resistance to quality still may exist (Spencer-Matthews 2001; Sallis 2002; EUA 2010), this study demonstrates that they are surely not the dominant voice of the teachers.

The second research question focuses on the values that, according to the teaching staff, are important for the preferred situation of their departments. It can be concluded from this study that teachers prefer the flexibility-oriented organisational values (Human Relations and Open System) above the control-oriented values (Rational Goal and Internal Process). This preference is also significant within most of the eighteen departments. Teaching staff prefer values such as involvement, cohesion, flexibility, and innovations above values focusing on stability, control and 
information management. This conclusion does not imply that the flexibility oriented organisational values are already actually prevailing within the daily practice of departments of higher education and of higher education as a whole. There may be a gap between what people think, the values they prefer and the values they put into practice (Brunsson 1989; Argyris 1990; Berings 2009; Kleijnen et.al. 2009). It might be possible that, despite their positive conceptions of quality as enhancement and improvement, teachers often are not in a position to shape the structural conditions for quality in their departments (Harvey 2006; Mundet Hiern et al. 2006; EUA 2010).

Finally it can be concluded that the quality conception of enhancement and improvement and flexibility-oriented values are positively related to each other and that the conception of compliance and accountability and control-oriented organisational values are also positively related to each other, albeit somewhat weaker. These findings are in line with expectations, although the relationships are not very strong. Besides it appears that a preference for flexibility oriented organisational values is also slightly positively correlated with the quality conception of compliance and accountability. A possible explanation for this finding might be that the two conceptions of quality also correlate positively with each other $(r=0.33)$. They do neither exclude each other nor are they mutually independent. This supports Harvey and Newton's expectation $(2007,232)$ that the two conceptions are not "two ends of a single continuum but two distinct and only partly related dimensions.". The conceptions of quality remain complex and intricate. Although they can be distinguished, they cannot be separated.

The findings of this study offer interesting perspectives for the further development of a quality culture in higher education. Quality management can link up neatly with the quality conceptions of teaching staff themselves and with their preferences for flexible organisational values. Management should allow the teachers themselves to formulate and discuss the preferred transformations for their students and the improvements they would like to implement in their departments and in their programmes. Furthermore, (inter)national external quality assurance systems should refrain from focussing primarily and exclusively on compliance with standards and criteria. Rather, it is more important to examine the degree to which management and teaching staff coordinate their improvement objectives, and systematically and consistently shape such objectives (Van Hout 2006). Quality demands not only a top-down approach, but above all a continuous cultural shift, "working within the framework of the existing culture, rather than going to war with it" (Cruickshank 2003, 1165). This demands deep understanding of organisational culture and commitment, ownership and involvement of both teachers and management.

There are methodological limitations to this study. A first limitation might result from the limited number of respondents and low response rate. The number of 
respondents and the response rate were indeed low, but nevertheless the differences reported in this study between the various investigated cognitions and preferred values are clear, substantial and significant. Further research is of course needed to further validate the findings of this study across other departments and a bigger sample of teachers per department. Secondly, the scales used to measure quality conceptions in this study need further validation across different contexts. A third limitation is that organisational values and all other variables were measured by means of a survey, as was also done in other studies (e.g. Howard 1998; Watty 2006). Although the resulting quantitative data provide interesting findings, measuring conceptions of quality and values is complex (Sallis 2002; Hitlin and Piliavin 2004). Further qualitative studies are needed to investigate conceptions of quality and organisational values more in-depth, e.g. by conducting interviews with teachers. Finally, the present study does not focus on the occurrence of existing, systematic, quality-oriented processes in the departments and on the gaps between conceptions and practice. Further qualitative studies could also shed more light on barriers that impede the deployment of an effective quality culture and of suitable practices to deal with them.

\section{References}

Argyris, C. 1990. Overcoming organizational defenses. Facilitating organizational Learning. Boston, MA: Allyn and Bacon.

Berings, D. 2009. Reflection on quality culture as a substantial element of quality management in higher education. Paper presented at the 4th European Quality Assurance Forum, in Copenhagen, Denmark.

Brundrett, M., and C. Rhodes. 2011. Leadership for quality and accountability in education. London: Routledge.

Brunsson, N. 1989. The organization of hypocrisy. Talk, decisions and actions in organizations. Chichester: John Wiley \& Sons.

Cameron, K.S., and R.E. Quinn. 1999. Diagnosing and changing organizational culture. Based on the competing values framework. Reading, MA: Addison-Wesley.

Cartwright, M.J. 2007. The rhetoric and reality of 'quality' in higher education. An investigation into staff perceptions of quality in post-1992 universities. Quality Assurance in Education 15, no. 3: 287-301.

Cruickshank, M. 2003. Total quality management in the higher education sector: a literature review from an international and Australian perspective. TQM \& Business Excellence 14, no. 10: 1159-1167.

European University Association, EUA. 2006. Quality culture in European universities:A bottom-up approach, Report on the three rounds of the quality culture project 2002-2006. Brussels: EUA.

European University Association, EUA. 2010. Examining quality culture: Part I - Quality assurance processes in higher education institutions. Brussels: EUA.

Findlow, S. 2008. Accountability and innovation in higher education: A disabling tension? Studies in Higher Education 33, no. 3: 313-329.

Gibson, A. 1986. Inspecting education. In Standards and Criteria in Higher Education, ed. G. Moodie, 128135. Milton Keynes: SRHE \& Open University Press.

Harvey, L. 2006. Quality culture, quality assurance and impact. Overview of discussions. In Embedding quality culture in higher education. A selection of papers from the $1^{\text {st }}$ European F orum for Quality Assurance. Brussels: EUA. 
Harvey, L., and D. Green. 1993. Defining quality. Assessment \& Evaluation In Higher Education 18, no. 1: 9-34.

Harvey, L, and J. Newton. 2007. Transforming Quality Evaluation: Moving on. In Quality Assurance in Higher Education. Trends in Regulation, Translation and Transformation, eds. D.F. Westerheijden, B. Stensaker, and M.J. Rosa, 225-245. Dordrecht: Springer.

Harvey, L., and B. Stensaker. 2008. Quality Culture: understandings, boundaries and linkages. European Journal of Education 43, no. 4: 427-442.

HBO-raad. 2009. Feiten en cijfers, personeel in het hoger beroepsonderwijs [Factsheet, employment in universities of applied sciences]. Den Haag: HBO-Raad.

Hitlin, S., and J.A. Piliavin. 2004. Values: Reviving a dormant concept. Annual review of sociology 30: 359393.

Hofstede, G. 2001. Culture's consequences: comparing values, behaviors, institutions and organizations across nations. $2^{\text {nd }}$ ed. Thousand Oaks, Ca: Sage.

Houston, D. 2008. Rethinking quality and improvement in higher education. Quality Assurance in Education 16, no. 1: 61-79.

Howard, G. 1998. Validating the competing values model as a representation of organizational cultures, International Journal of Organizational Analysis 6, no. 3: 231-250.

Huisman, J., and J. Currie. 2004. Accountability in higher education: Bridge over troubled water? Higher Education 48, no. 4: 529-551.

Kezar, A., and P. Eckel. 2002. The effect of institutional culture on change strategies in higher education. Higher Education 73, no. 4: 435--460.

Kleijnen, J., D. Dolmans, J. Willems, A. Muijtjens, and J. Van Hout. 2009. Organisational values in higher education: perceptions and preferences of staff. Quality in Higher Education 15, no. 3: 233-249.

Lomas, L. 2004. Embedding quality: The challenges for higher education. Quality assurance in education 12, no. 4: 157-165.

Lomas, L. 2007. Zen, motorcycle maintenances and quality in higher education. Quality Asurance in Education 15, no. 4: 402-412.

Mundet Hiern, J., A. Suñé Torrents, J.M. Sallán Leyes, and V. Fernández Alarcón. 2006. The impact of defensive barriers on organizational performance and learning, Management \& Avenir 2, no. 8: 2737.

Newton, J. 2000. Feeding the beast or improving quality?: Academics' perceptions of quality assurance and quality monitoring. Quality in Higher Education 6, no. 2: 153-163.

Newton, J. 2002. Views from below: Academics coping with quality. Quality in Higher Education 8, no. 1: 39-61.

Patterson, M.G., M.A. West, V.J. Shackleton, J.F. Dawson, R. Lawthom, S. Maitlis, D.L. Robinson and A.M. Wallace. 2005. Validating the organizational climate measure: Links to managerial practices, productivity and innovation. Journal of Organizational Behavior 26, no. 4: 379-408.

Quinn, R.E., S.R. Faerman, M.P. Thompson, and M.R. McGrath. 2007. Becoming a Master Manager: A competing values approach, $4^{\text {th }}$ ed. New York, NY: Wiley.

Sallis, E. 1996 and 2002. Total quality management in education. $2^{\text {nd }}$ and $3^{\text {rd }}$ edn. London: Kogan.

Spencer-Matthews, S. 2001. Enforced cultural change in academe. A practical case study: implementing quality management systems in higher education. Assessment \& Evaluation in Higher Education 26, no. 1: 51-59.

Van Hout, J. 2006. Kwaliteitszorg in het HO: nog veel werk aan de winkel' [Quality management in higher education: a lot remains to be done]. In Vernieuwing in het hoger onderwijs. Onderwijskundig handboek [Innovations in higher education. Handbook of education], Eds. J. Van Hout, G. Ten Dam, M. Mirande, C. Terlouw and J. Willems, 215-228. Assen: Van Gorcum.

Watty, K. 2006. Want to know about quality in higher education? Ask an academic. Quality in higher education 12, no. 3: 291-301. 


\section{Appendix 1. Conceptions of quality: Items, Mean, SD and $N$}

\begin{tabular}{|c|c|c|c|}
\hline Compliance and accountability & Mean $^{\mathrm{a}}$ & $S D$ & $N$ \\
\hline $\begin{array}{l}\text { 1. A programme has quality if it makes appropriate use of public funds, for } \\
\text { instance guaranteeing a high percentage of graduates. }\end{array}$ & 3.06 & 1.02 & 266 \\
\hline $\begin{array}{l}\text { 2. A programme has quality if virtually all components conform to specific, pre- } \\
\text { defined criteria. }\end{array}$ & 3.56 & 0.93 & 264 \\
\hline $\begin{array}{l}\text { 3. Quality means that the programme complies with and conforms to basic } \\
\text { accreditation standards. }\end{array}$ & 3.11 & 1.15 & 264 \\
\hline $\begin{array}{l}\text { 4. A programme has quality if it scores consistently higher than other pro- } \\
\text { grammes in national evaluations and rankings (comparisons). }\end{array}$ & 3.34 & 1.03 & 264 \\
\hline 5. UAS programmes are generally of a high quality. Quality is a given. & 2.88 & 0.80 & 262 \\
\hline $\begin{array}{l}\text { 6. A programme has quality if the students can generally assume that compo- } \\
\text { nents and projects are well executed. }\end{array}$ & 3.44 & 0.92 & 262 \\
\hline $\begin{array}{l}\text { 7. Quality means that the programme conforms to objective, measurable } \\
\text { criteria, based on a high degree of internal and external consensus. }\end{array}$ & 3.76 & 0.95 & 265 \\
\hline 8. A programme has quality if it manages to achieve its goals and objectives. & 3.95 & 0.79 & 266 \\
\hline 9. A programme has quality if it produces high grades. & 2.28 & 0.88 & 265 \\
\hline \multicolumn{4}{|l|}{ Enhancement and improvement } \\
\hline $\begin{array}{l}\text { 10. A programme has quality if it benefits the students' future career or aca- } \\
\text { demic prospects. }\end{array}$ & 4.27 & 0.69 & 264 \\
\hline $\begin{array}{l}\text { 11. A programme has quality if it empowers students to consciously and } \\
\text { critically shape their own development. }\end{array}$ & 4.34 & 0.76 & 264 \\
\hline $\begin{array}{l}\text { 12. A programme has quality if it dovetails with the demands and require- } \\
\text { ments of the professional work environment and students. }\end{array}$ & 4.29 & 0.75 & 264 \\
\hline $\begin{array}{l}\text { 13. A programme has quality if it is carefully put together, prepared and im- } \\
\text { plemented. }\end{array}$ & 4.20 & 0.74 & 264 \\
\hline 14. A programme has quality if it is committed to ongoing improvement. & 4.29 & 0.80 & 266 \\
\hline 15. A programme has quality if it delivers on its promises made to students. & 4.12 & 0.78 & 265 \\
\hline $\begin{array}{l}\text { 16. A programme has quality if it empowers students to acquire as many new } \\
\text { competencies, knowledge and skills as possible. }\end{array}$ & 4.13 & 0.84 & 265 \\
\hline $\begin{array}{l}\text { 17. The degree of satisfaction of students and the professional work environ- } \\
\text { ment says a lot about the quality of a programme. }\end{array}$ & 4.06 & 0.84 & 265 \\
\hline $\begin{array}{l}18 \text { A high-quality programme has a good reputation and can therefore offer } \\
\text { the best placement or work-based learning opportunities. }\end{array}$ & 3.57 & 0.96 & 263 \\
\hline Valid listwise & & & 252 \\
\hline
\end{tabular}

a) Five point scale: $1=$ fully disagree; $5=$ fully agree; $3=$ neutral 


\section{Appendix 2. Questions Organisational Culture Assessment Instrument (OCAI), items, mean, SD and $N$}

To what extent do you agree/disagree with the following statements in the preferred situation of your department? (The questionnaire was translated in Dutch.)

\begin{tabular}{|c|c|c|c|}
\hline \multirow{2}{*}{$\begin{array}{l}\text { OCAl (Cameron and Quinn, 1999). } \\
\text { Human relations model (HR): flexibility oriented, internal focus }\end{array}$} & \multicolumn{3}{|c|}{ Preferred } \\
\hline & Mean $^{\mathrm{a}}$ & $S D$ & $N^{b}$ \\
\hline 10 The organization is a very personal place. It is like an extended family. & & & \\
\hline People seem to share a lot of themselves. & 4.24 & 0.66 & 263 \\
\hline $\begin{array}{l}14 \text { The leadership in the organization is generally considered to exemplify } \\
\text { mentoring, facilitating or nurturing. }\end{array}$ & 4.19 & 0.66 & 259 \\
\hline $\begin{array}{l}18 \text { The management style in the organization is characterized by teamwork, } \\
\text { consensus and participation. }\end{array}$ & 4.15 & 0.63 & 259 \\
\hline 22 The glue that holds the organization together is loyalty and mutual trust. & & & \\
\hline Commitment to this organization runs high. & 4.16 & 0.67 & 262 \\
\hline $\begin{array}{l}26 \text { The organization emphasizes human development. High trust, openness, } \\
\text { and participation persist. }\end{array}$ & 4.22 & 0.62 & 260 \\
\hline $\begin{array}{l}30 \text { The organization defines success on the basis of the development of human } \\
\text { resources, teamwork, employee commitment, and concern for people. }\end{array}$ & 3.98 & 0.73 & 255 \\
\hline
\end{tabular}

Open system model (OS): flexibility oriented, external focus

11 The organization is a very dynamic and entrepreneurial place. People are willing to stick their necks out and take risks.

15 The leadership in the organization is generally considered to exemplify entrepreneurship, innovating or risk taking.

19 The management style in the organization is characterized by individual risk-taking, innovation, freedom and uniqueness.

23 The glue that holds the organization together is commitment to innovation and development. There is an emphasis on being on the cutting edge.

27 The organization emphasizes acquiring new resources and creating new challenges. Trying new things and prospecting for opportunities are valued.

31 The organization defines success on the basis of having the most unique or newest products. It is a product leader and innovator.

$\begin{array}{lll}3.98 & 0.77 \quad 258\end{array}$

Rational goal model (RG): control oriented, external focus

12 The organization is very results oriented. A major concern is with getting the job done. People are very competitive and achievement oriented.

16 The leadership in the organization is generally considered to exemplify a no-nonsense, aggressive, results-oriented focus.

20 The management style in the organization is characterized by hard-driving competitiveness, high demands, and achievement.

24 The glue that holds the organization together is the emphasis on achievement and goal accomplishment. Aggressiveness and winning are common themes.

28 The organization emphasizes competitive actions and achievement. Hitting stretch targets and winning in the marketplace are dominant. 


\begin{tabular}{|c|c|c|c|}
\hline Internal process model (IP): control oriented, internal focus & Mean $^{\mathrm{a}}$ & $S D$ & $N^{b}$ \\
\hline $\begin{array}{l}13 \text { The organization is a very controlled and structured place. Formal } \\
\text { dures generally govern what people do. }\end{array}$ & 3.36 & 0.86 & 263 \\
\hline 17 The leadership in the organization is generally considered to exem & & & \\
\hline coordinating, organizing, or smooth-running efficiency. & 3.99 & 0.74 & 260 \\
\hline $\begin{array}{l}21 \text { The management style in the organization is characterized by secur } \\
\text { employment, conformity, predictability, and stability in relationships. }\end{array}$ & 3.12 & 0.93 & 259 \\
\hline 25 The glue that holds the organization together is formal rules and $p$ & & & \\
\hline Maintaining a smooth-running organization is important. & 3.10 & 0.86 & 260 \\
\hline $\begin{array}{l}29 \text { The organization emphasizes permanence and stability. Efficiency, } \\
\text { and smooth operations are important. }\end{array}$ & 3.57 & 0.80 & 260 \\
\hline $\begin{array}{l}33 \text { The organization defines success on the basis of efficiency. Depen } \\
\text { delivery, smooth scheduling, and low-cost production are critical. }\end{array}$ & 3.40 & 0.84 & 253 \\
\hline
\end{tabular}

a) Five point scale: $1=$ fully disagree; $5=$ fully agree; $3=$ neutral

b) Missing cases: $\min .1, \max 13$ 



\section{CHAPTER 5}

\section{Does internal quality management contribute to more control or to improvement of higher education?}

A survey on faculty's perceptions ${ }^{3}$

\footnotetext{
${ }^{3}$ Published as: Kleijnen, J., Dolmans, D., Willems. J. \& Van Hout, J. (2011). Does internal quality management contribute to more control or to improvement of higher education? A survey on faculty's perceptions. Quality Assurance in Education, 19(2), 141-155.
} 


\begin{abstract}
Purpose - The purpose of this paper is to explore faculty's perceptions of quality management activities within their departments, attention being paid to relevant quality aspects and whether quality management contributes to control or improvement of higher education. Furthermore, it examines differences between departments and relationships between the different variables.
\end{abstract}

Design/methodology/approach - A questionnaire containing items with Likert-type answer scales was distributed to faculty $(\mathrm{N}=266)$ of 18 departments of universities of applied sciences in the Netherlands: 16 items dealt with quality management activities, 17 with attention paid to relevant quality aspects and ten with the perceived effects.

Findings - Faculty were neutral about the degree to which sufficient quality management activities were conducted within their departments. They were positive about the attention paid to relevant quality aspects. Furthermore, they were positive about the effects in terms of improvement and negative about the effects in terms of control. Significant differences were found between departments. Finally, positive correlations were found between management activities, attention being paid to quality aspects and the perceived effect in terms of improvement.

Research limitations/implications - The main limitations of this study is that only faculty's perceptions were measured, thus it is not clear whether these quality management activities really result in improvement in educational practice.

Practical implications - Departments paying little attention to quality aspects and with few quality management activities could really benefit from further increasing their quality management efforts.

Originality/value - Quality management is often seen as mainly contributing to control and managerialism. This study demonstrates that, according to faculty, quality management is influencing improvement positively.

Keywords: The Netherlands; Teaching staff; Universities of applied sciences; Quality management; Quality control; Quality improvement. 


\section{Introduction}

\section{Problem and aim}

Many authors contend that faculty in higher education institutions have a negative attitude towards quality management. They see it as bureaucratic, a cause of ritualistic paperwork and interference with professionals' efforts to generate quality (Newton, 2000, 2002; Koch, 2003; Milikan and Colohan, 2004; Watty, 2006; Lomas, 2007). Others, however, claim that quality management has positive effects (Martens and Prosser, 1998; Brennan and Shah, 2000). This study is conducted to investigate the perceptions of faculty within institutes of higher education on this topic.

Quality management within departments comprises all activities and processes that are deliberately carried out to design, assure, evaluate and improve teaching and learning (Grant et al., 2004). It implies developing missions and strategies, setting standards for professionals in teaching, administration and support. It comprises internal quality assessments, periodic self-evaluations, external accreditation procedures, external consultations with the field (professionals and their employers) and benchmarking. The core of quality management encompasses methodical proceedings of the Plan/Do/Check/Act (PDCA) cycle and an orientation towards continuous improvement, often termed as total quality management (Lewis and Smith, 1994; Sallis, 2002; Vettori et al., 2006; Venkatraman, 2007). Procedures and results of quality management are often well-documented.

In quality management attention is given to a broad array of aspects related to teaching and learning, which are frequently divided into three groups: inputs or requirements, processes and outputs or results (Owlia and Aspinwall, 1996; Segers, 1993; Vroeijensteijn, 1995; Cave et al., 1997; Wiklund et al., 2003; Van Damme, 2004; Sahney et al., 2004; Becket and Brookes, 2006). Inputs or requirements include financial, physical and human resources. Processes include technical and professional but also relational variables such as accessibility of the professional, friendliness and credible communication (Parasuraman et al., 1991; Yeo, 2008). Output factors include pass/fail rates and competency levels at graduation but also indirect factors, such as career opportunities for alumni and impact on the labour market and society (Segers, 1993; Vroeijensteijn, 1995; Van Damme, 2004). These factors contribute to the core goal of education: the transformation of the learner by which the initial competencies of enrolling students are transformed into the competencies of graduate students and teachers' competencies and qualities are transformed into the qualities and competencies of graduates (Harvey and Green, 1993; Martens and Prosser, 1998; Van Damme, 2004; Watty, 2006; Becket and Brookes, 2006; Harvey and Newton, 2007; Venkatraman, 2007; Rosa and Amaral, 2007).The key question is whether quality management contributes to this learning process and to improvement of education or merely "feeds the beast of bureauc- 
racy" (Newton, 2000) by creating burdensome but futile management procedures and paperwork.

\section{Effects of quality management: a review of literature}

Quality management is a delicate process that is subject to competing values and strong ambivalences. Its effects in terms of improvement of educational quality are controversial. Quality management often gives rise to standardisation and control, which may collide with the need for adaptation to new developments, innovation and individual professional accountability. Advocates of quality management frequently resort to education and management rhetoric and claim wonderful beneficial effects for the quality of higher education. Reality, however, can hardly meet these wonderful claims and therefore the adversaries often spawn equally impassioned counter-rhetoric (Zbaracki, 1998; Ahaus, 2006). The question, however is what the real effects are (Harvey and Newton, 2004, 2007; Ahaus, 2006; Stensaker, 2006). According to Harvey \& Newton (2004, p.157), quality has "contributed little to any effective transformation of the student learning experience". Negative effects emerge from a strong emphasis on external control and overestimating accountability. This might provoke a shift of power from the departments to the institutional level and to government (Newton, 2002). Policies "to increase productivity and control while reducing resources" may have a negative impact on educational quality and undermine "students' learning experience" (Milliken and Colohan, 2004, p. 389). Academics may respond to perceived excessive control and bureaucracy in dysfunctional ways or even by withdrawal (Watty, 2002; Newton, 2002; Milliken and Colohan, 2004; Cartwright, 2007). External control reinforces existing norms and conformity and often leads to imitation of proven strategies and actions. (Van der Zee, 1990; Newton, 2002; Wiklund et al., 2003). Furthermore, there is a tendency to emphasise measurable aspects of quality, issues that can easily be made visible, irrespective of their importance for quality while the really big issues are neglected. Institutions may over-analyse whether things are being done well, but fail to assess whether the right things are being done (Van der Zee, 1990; Koch, 2003). Window-dressing, game playing and deceptive practices in benchmarking and review processes are reported to replace attention to quality (Van Damme, 2004; Newton, 2002). Staff members might feel that their individual professional responsibility is impaired or damaged, due to which these negative effects may arise (Newton, 2002; Wiklund et al., 2003).

Other authors, however, have also pointed to positive effects. They emphasise responsibility and breaking through prevailing internal orientations (Brennan and Shah, 2000; Westerheijden, 1999; Westerheijden et al., 2007; Stensaker, 2006). Quality management leads to more attention being paid to the teaching function and the teaching methods of departments (Brennan and Shah 2000). It empowers 
students by taking account of their perspectives and interests (Brennan and Shah, 2000) and it strengthens professional competencies, by encouraging new forms of teamwork and collaboration (Martens and Prosser, 1998; Stensaker, 2006). Institutions and departments are stimulated to underpin their decisions by more transparent and open information (Brennan and Shah, 2000). Scientific evidence for these positive and negative views, however, is lacking so far and needs further investigation (Westerheijden et al., 2007; Hulpiau and Waeytens, 2001).

Faculty's perceptions of the effects of quality management will probably differ across departments. Although departments within institutions of higher education are subject to pressures originating at international, national and institutional levels which tend to control the relationships between quality, costs and accountability (Vroeijensteijn, 1990; Lewis and Smith, 1994), the department is still the primary activity system in higher education. As Weick (1976) stated, institutions of higher education are loosely coupled systems. Despite efforts by the central organisation to gain more control, there is plenty of room for self-determination by departments and their professionals (Knight and Trowler, 2000). The differences between departments regarding the perceived effects of quality management may be due to variation in organisational cultures and traditions, such as differences in emphasis on internal communication and teamwork, to differences in organisational and hierarchical structure or in leadership (Harvey, 2007, Harvey and Stensaker, 2008), to the department's academic discipline (Becher an Trowler, 2001), and also to the amount of quality management actually carried out within each department.

\section{Research questions}

This paper examines faculty's perceptions about quality management and its effects in order to seek answers to the following research questions: The first is, whether, according to faculty, sufficient quality management activities are conducted within their departments. A second question is whether they think that sufficient attention is paid to relevant quality aspects within their departments. Third, do they think that quality management within their departments makes an effective contribution to educational improvement or rather enhances centralised control? Fourthly, do faculty's perceptions of quality management activities, amount of attention paid to relevant quality aspects and effects of quality management differ between departments? And finally, are there any relationships between faculty's perceptions of quality management activities, amount of attention paid to relevant quality aspects and effects of quality management? 


\section{Methods}

\section{Context and Participants}

The Netherlands has a binary system of higher education with traditional universities and universities of applied science (UAS). About 40 universities of applied sciences are approved and funded by the government and offer curricula leading to bachelor's and master's degrees in a wide range of subjects. They are organised in departments and have a student population of over 400,000 students (HBO-Raad, 2010). Because of homogeneity this study focuses on these Dutch UAS.

The study is based on a survey conducted between March and September 2008. In total 30 departments participated in the survey, of which all teaching staff were asked to fill out a questionnaire. A total of 991 questionnaires were sent out; 316 $(32 \%)$ were returned. Eighteen departments had 10 or more respondents. This survey is limited to the 266 respondents from these 18 departments. The response rates of these 18 departments ranged from 18 to $63 \%$ per department.

Table 1. Departments and respondents by scientific area

\begin{tabular}{lccc}
\hline Scientific area & Departments & Respondents & $\begin{array}{c}\text { \% of total number of } \\
\text { respondents }\end{array}$ \\
\hline Economics and Business Administration & 2 & 28 & 11 \\
Health Care & 6 & 90 & 34 \\
Education (teacher training) & 3 & 40 & 15 \\
Social Welfare & 3 & 51 & 19 \\
Engineering and Technology & 3 & 39 & 15 \\
Fine and Performing Arts & 1 & 18 & 7 \\
Total & 18 & 266 & 101 \\
\hline
\end{tabular}

Note: The percentages do not sum to 100 exactly due to rounding up.

The distribution of departments and respondents over scientific areas is shown in Table 1 . Of the respondents 53 per cent were male and the median age was 48.2 years. The participants' highest academic qualifications were bachelor's degree (32.5 per cent), master's degree (59 per cent) and doctoral degree (4.5 per cent), while 4 per cent did not provide this information. About 65 per cent of the respondents had held a position within a university of applied sciences for more than six years and 85 per cent were employed between 50 per cent and full time. About one-third (31 per cent) were heavily involved in quality management, and 38 per cent had been intensively involved in recent accreditation activities. According to data published by the Council of the Universities of Applied Sciences (HBO-Raad, 2009) the study sample appears to be representative with respect to age, gender and academic qualifications. The employment data suggest that the respondents 
have had sufficient experience within higher education to give well considered answers to the survey questions.

\section{Instruments}

In order to investigate the extent to which quality management was implemented, a 16-item questionnaire was developed, based on the results of a literature review. The items on quality management activities dealt with quality design and quality assurance, with inspection, evaluation and improvement activities and with involvement of faculty in quality management, and communication. For each item the participants were asked to indicate if in their opinion the relevant activity was conducted to a sufficient degree within their department. Factor analysis using principal components analysis with Varimax rotation (orthogonal) revealed three factors with eigenvalues $\geq 1$. This resulted in the 'quality management activities' scale (QMA scale) consisting of 16 items and three subscales (Appendix 1). The subscales relate to aspects of the 'PDCA cycle' with seven items, 'external evaluation and communication' with four items, and 'internal evaluation and communication' with three items. Internal consistency (Cronbach's $\alpha$ ) of the scale and three subscales was 0.93, $0.89,0.84$ and 0.73 , respectively. Correlations between the subscales varied between 0.63 and 0.68 (Pearson's $r$ ). All correlations were significant at $p \leq 0.01$ (twotailed).

Seventeen-items were developed to measure faculty's perceptions of the attention paid to relevant quality aspects within their department. The items relate to input, process and output factors and faculty are asked to indicate if sufficient attention is paid to these aspects. The items were derived from the national student survey of the Netherlands Association of UAS (HBO-Raad, 2007). Factor analysis using the same procedure as for the quality management activities questionnaire resulted in one scale and three subscales (Appendix 2). The 'attention to quality aspects' scale (AQA scale) contains 17 items (Cronbach's $\alpha=0.91$ ); the 'teaching and learning' subscale comprises nine items concerning the primary process (Cronbach's $\alpha=0.88$ ); the 'information and facilities' subscale contains five items relating to input aspects (Cronbach's $\alpha=0.81$ ); and the 'results' subscale contains three items relating to output aspects (Cronbach's $\alpha=0.67$ ). The correlations between the subscales varied from 0.47 to 0.68 (Pearson's $r$ ). All correlations were significant at $p \leq 0.01$ (two-tailed).

The third part of the questionnaire contains ten items about the effects of quality management, which were also derived from a literature review. Several items focus on whether, according to faculty, quality management activities enhance their professional work and stimulate improvement and innovation of education within their department, other items focus on control (Appendix 3). Factor analysis re- 
sulted in two scales: 'perceived improvement' consisting of seven items (Cronbach's $\alpha=0.92$ ) and 'perceived control' consisting of three items (Cronbach's $\alpha=0.68$ ).

All questionnaire items were formulated as statements and participants were asked to indicate their agreement on a five-point Likert scale (1=fully disagree; $5=$ fully agree; 3 is regarded as neutral). If the respondent had no opinion, he was asked not to fill in the answer.

\section{Data analysis}

In order to answer the first three research questions the mean scores per item and per scale were computed, as well as the score range, the standard error, and the standard deviation per scale. In order to answer the fourth research question a oneway analysis of variance (ANOVA) was conducted, with department as the random factor and the variance within a department as the error term. The influence of sample's characteristics like age, gender, academic qualifications, years and size of appointment have been tested but they did not influence the staff's perception of quality management or its effects. In order to answer the fifth research question Pearson's correlation coefficients for relationships between the scales were calculated at the level of individual respondents.

\section{Results}

\section{Perception of quality management activities}

The first research question investigates how faculty perceive the implementation of quality management activities (QMA) in their departments. Are they conducted to a sufficient degree? The results revealed neutral scores on QMA. The mean score on the QMA scale is neutral with $M=3.07 \quad(S D=0.73)$. The mean scores on the 'PDCA'subscale and the subscales 'external evaluation and communication' and 'internal evaluation and communication' are $M=3.07,2.73$ and 3.26, respectively, with $S D=0.78,0.86$ and 0.84 (Table 2). For the QMA scale as a whole, the nonresponse, indicating that the respondent has no opinion, is 9 per cent. For the 'external evaluation and communication' subscale it is 23 per cent. These findings show that, overall, faculty are neither very satisfied nor dissatisfied with the degree to which quality management activities, and especially the 'PDCA cycle', are executed within their departments. They are relatively more satisfied with internal evaluation and communication' and less with 'external evaluation and communication' about which a relatively large percentage are poorly informed. 
Table 2. Perception of 'quality management activities', 'attention paid to relevant quality aspects' and 'effects of quality management': mean scores on the scales and subscales, number of respondents $(N)$, number of items, score range (minimum-maximum), standard error (SE), standard deviation (SD) and Cronbach's $\alpha$.

\begin{tabular}{|c|c|c|c|c|c|c|c|c|}
\hline & $N^{\mathrm{a}}$ & Items $^{\mathrm{b}}$ & $\begin{array}{l}\text { Mini- } \\
\text { mum }\end{array}$ & $\begin{array}{l}\text { Maxi- } \\
\text { mum }\end{array}$ & Mean $^{c}$ & $S E$ & $S D$ & Cronbach's $\alpha$ \\
\hline \multicolumn{9}{|l|}{$\begin{array}{l}\text { Quality management } \\
\text { activities }\end{array}$} \\
\hline PDCA subscale & 231 & 7 & 1.14 & 5.00 & 3.07 & 0.051 & 0.78 & 0.89 \\
\hline External evaluation and & 201 & 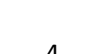 & 100 & 500 & & $0 \cap 61$ & & \\
\hline Internal evaluation and & 204 & 4 & 1.00 & 0.00 & 2.10 & 0.001 & 0.00 & 0.04 \\
\hline communication subscale & 259 & 3 & 1.00 & 5.00 & 3.26 & 0.052 & 0.84 & 0.73 \\
\hline QMA scale & 228 & 16 & 1.09 & 5.00 & 3.07 & 0.048 & 0.73 & 0.93 \\
\hline \multicolumn{9}{|l|}{$\begin{array}{l}\text { Attention paid to quality } \\
\text { aspects }\end{array}$} \\
\hline $\begin{array}{l}\text { Teaching and learning } \\
\text { subscale }\end{array}$ & 262 & 9 & 1.22 & 5.00 & 3.42 & 0.044 & 0.70 & 0.88 \\
\hline \multicolumn{9}{|l|}{ Information and facilities } \\
\hline subscale & 261 & 5 & 1.40 & 5.00 & 3.47 & 0.045 & 0.72 & 0.81 \\
\hline Results subscale & 258 & 3 & 1.00 & 5.00 & 3.44 & 0.046 & 0.74 & 0.67 \\
\hline \multicolumn{9}{|l|}{ Attention to quality } \\
\hline \multicolumn{9}{|l|}{ Perceived effects } \\
\hline Perceived Improvement & 259 & 7 & 1.00 & 5.00 & 3.55 & 0.056 & 0.90 & 0.92 \\
\hline Perceived control & 258 & 3 & 1.00 & 5.00 & 2.42 & 0.056 & 0.90 & 0.68 \\
\hline
\end{tabular}

Notes:

a If the (sub)scales did not include minimal numbers of filled in items, a missing value was recorded.

${ }^{\mathrm{b}}$ See appendices 1-3

${ }^{\mathrm{c}}$ Five-point scale: 1 =fully disagree; $5=$ fully agree; 3 = neutral

\section{Perception of attention paid to relevant quality aspects}

The second research question addresses faculty's perceptions of attention paid to relevant quality aspects. Does the department pay sufficient attention to relevant aspects of quality of teaching and learning? The mean score on the 'attention to quality aspects' (AQA) scale is $M=3.44(S D=0.62)$ and the mean scores on the subscales on 'teaching and learning', 'information and facilities' and 'results' are $M=3.42,3.47$ and 3.44, respectively, with $S D=0.70,0.72$ and 0.74 (Table 2). These results indicate that, overall, faculty's perceptions are fairly positive with regard to attention paid to all relevant quality aspects.

\section{Perception of effects of quality management}

The third research question focuses on faculty's perceptions of the effects of quality management. It impinges on the core issue of this paper: do faculty perceive quality 
management as having a predominantly negative effect on the work of professionals and on the development of the department or do they see positive effects? The mean score on the 'perceived improvement' scale is $M=3.55(S D=0.90)$ and the mean score on the 'perceived control' scale is $M=2.42(S D=0.90)$ (Table 2). This implies that, overall, faculty are positive about the effects of quality management in terms of improvement and negative about the effects in terms of control.

\section{Variation between departments}

The last two research questions examine variation between and within departments concerning quality management. The departments' scores on the 'quality management activities' (QMA) scale vary from $M=3.97$ to $M=2.08$. The scores on the scale measuring whether sufficient attention is paid to various quality aspects (AQA) vary from quite high $(M=4.24)$ to slightly below neutral $(M=2.80)$ and the same applies to 'perceived improvement', with mean scores of departments varying from $M=4.25$ to $M=2.93$. These differences are all substantial and significant: for ' $Q M A$ ' $F(17,210)=$ 6.379, $\mathrm{p} \leq 0.001$; for 'AQA' $F(17,238)=9.132, \mathrm{p} \leq 0.001$ and for 'perceived improvement' $F(17,241)=3.312, p \leq 0.001$ (Table 3 ). The scores on 'perceived control' do not differ significantly between departments. These findings indicate that, in the perception of faculty, departments really vary considerably on 'quality management activities', 'attention paid to quality aspects' and also in terms of 'perceived improvement' as an effect of quality management. 
Table 3. ANOVA: Variations between and within departments based on the 'quality management activities' scale (QMA), the 'attention to quality aspects' scale (AQA), 'perceived improvement' and 'perceived control': Sum of squares, Degrees of freedom $(d f)$, Mean square between/Mean square within ( $F$-ratio), Significance (Sig.), eta and eta $^{2}$ (Sum of squares between/sum of squares total)

\begin{tabular}{|c|c|c|c|c|c|c|c|c|c|}
\hline & & & $\begin{array}{l}\text { Sum of } \\
\text { Squares }\end{array}$ & $d f$ & $\begin{array}{l}\text { Mean } \\
\text { Square }\end{array}$ & $\boldsymbol{F}$ & Sig. & Eta & $\mathrm{Eta}^{2}$ \\
\hline \multirow{3}{*}{$\begin{array}{l}\text { QMA scale * } \\
\text { department }\end{array}$} & Between groups & (Combined) & 40.927 & 17 & 2.407 & 6.379 & .000 & .584 & .341 \\
\hline & Within groups & & 79.259 & 210 & .377 & & & & \\
\hline & Total & & 120.186 & 227 & & & & & \\
\hline \multirow{3}{*}{$\begin{array}{l}\text { AQA scale * } \\
\text { department }\end{array}$} & Between groups & (Combined) & 39.108 & 17 & 2.300 & 9.132 & .000 & .628 & .395 \\
\hline & Within groups & & 59.958 & 238 & .252 & & & & \\
\hline & Total & & 99.066 & 255 & & & & & \\
\hline \multirow{3}{*}{$\begin{array}{l}\text { Perceived } \\
\text { improvement* } \\
\text { department }\end{array}$} & Between groups & (Combined) & 39.719 & 17 & 2.336 & 3.312 & .000 & .435 & .189 \\
\hline & Within groups & & 179.017 & 241 & .705 & & & & \\
\hline & Total & & 209.736 & 258 & & & & & \\
\hline \multirow{3}{*}{$\begin{array}{l}\text { Perceived } \\
\text { control* }^{*} \\
\text { department }\end{array}$} & Between groups & (Combined) & 15.280 & 17 & .899 & 1.116 & .339 & .271 & .073 \\
\hline & Within groups & & 193.276 & 240 & .805 & & & & \\
\hline & Total & & 208.556 & 257 & & & & & \\
\hline
\end{tabular}

* QMA scale per department, etc.

\section{Relationships between the scales}

The last research question was formulated to investigate whether perceived quality management effects are related to faculty's experiences with quality management activities and the attention paid to quality aspects within their departments. The answers were analysed at the level of individual respondents (Table 4). The 'perceived improvement' scale correlates strongly with the 'quality management activities' scale and the scale measuring the 'attention paid to different quality aspects', with Pearson's $r=0.59$ and 0.51 respectively. This indicates that faculty perceive more effects of improvement when they are more satisfied with the quality management within their departments. The findings also show a strong relationship between 'quality management activities' and 'attention paid to quality aspects' (Pearson's $r=0.73$ ). This implies that faculty see quality management activities and attention paid to quality aspects as a one package deal. Finally, there is a small but significant negative correlation between 'perceived improvement' and 'perceived control' (Pearson's $r=-0.19$ ). These correlations are significant at the level of $p \leq$ 0.01 (two-tailed). 
Table 4. Pearson correlations between the 'quality management activities scale' (QMA), the 'attention to quality aspects' scale (AQA), 'perceived improvement' and 'perceived control' scores at the level of individual respondents

\begin{tabular}{lcccc}
\hline & QMA scale & AQA scale & Perceived improvement & Perceived control \\
\hline QMA scale & 1 & $0.73^{*}$ & $0.59^{*}$ & -0.08 \\
AQA scale & & 1 & $0.51^{*}$ & -0.10 \\
Perceived improvement & & & 1 & $-0.19^{*}$ \\
Perceived control & & & 1 \\
\hline
\end{tabular}

* Correlation is significant at the 0.01 level (2-tailed).

\section{Conclusions and discussion}

This study investigated faculty's perceptions of quality management in their departments. The results demonstrated that faculty were neutral about the degree to which sufficient quality management activities were conducted within their departments, especially with regard to the systematic application of the PDCA cycle. These rather neutral scores indicate that, in general, quality management may not yet be an obvious activity in many departments. In addition, the non-response rates on the 'external evaluation and communication' subscale indicate that respondents often had no opinion on this subject. This suggests poor internal communication about these activities within the department. The results also revealed that, generally, faculty were positive about the attention paid to the relevant quality aspects within their departments: 'teaching and learning', 'information and facilities' and 'results'. Paying attention to quality aspects might be more easy to show than engaging in organised quality management activities. Furthermore, the results demonstrated that faculty were positive about the effects of quality management in terms of improvement and negative about its effects in terms of control. Faculty indicated that quality management enhances both their work and educational quality within their departments. These findings are striking, because it is often argued that quality management is generally perceived as bureaucratic and having negative effects (Koch, 2003; Milliken and Colohan, 2004; Cartwright, 2007; Lomas, 2007). The results of this study, however, demonstrate that faculty belief that quality management results in improvement and not only results in control.

Another remarkable finding relates to differences between departments. According to perceptions of faculty, departments vary substantially. They perform quality management activities to different degrees and differ in the amount of attention paid to relevant quality aspects. Perception of improvement as an effect of quality management also shows considerable variations across departments. These differences might be explained by variations in organisational culture and traditions, such as differences in emphasis on internal communication or teamwork, to differences in organisational and hierarchical structure or in leadership (Harvey, 2007, 
Harvey and Stensaker, 2008) and to the department's academic discipline (Becher an Trowler, 2001).

Finally, the findings demonstrated that the 'perceived improvement' effect of quality management is strongly positively associated with the perceived amount of quality management activities conducted within the department and the attention that is being paid to quality aspects, which may indicate a strong quality culture in some departments and the absence of it in others. Some departments do well while others perform poorly. This seems to confirm the observation by Knight and Trowler, (2000) that departments are not powerless in the face of institutional, national and international developments. Departments seem to have a vigorous amount of freedom in creating their own quality culture.

A first methodological limitation of this study is the low response rate per department. However, it is also important to keep in mind that at least 10 teachers' responses per department were available and the sample size was representative as explained in the methods section. The main limitation, however, is that only teachers' perceptions were measured in this study. This begs the question whether these perceptions reflect real practice and whether quality management does really result in continuous improvement in educational practice.

Further studies are needed. A more qualitative study might help to gain a deeper understanding of the differences between departments. It would especially be of interest to investigate the organisational cultures of departments. Furthermore, it would be worth investigating whether the findings of this study correlate with other measures, such as the perceptions of students or external stakeholders.

\section{References}

Ahaus, K. (2006), "Kwaliteit uit waardering [Quality through appraisal]", Paper presented at the Faculty of Management and Organization of the University of Groningen on acceptance of his appointment to the endowed chair of Quality Management at the Management Science Department, University of Groningen, Groningen, 4 April.

Becher, T. and Trowler, P. (2001), Academic Tribes and Territories: Intellectual Enquiry and the Cultures of Discipline, $2^{\text {nd }}$ edn., Open University Press, Buckingham.

Becket, N. and Brookes, M. (2006), "Evaluating quality management in university departments", Quality Assurance in Education, Vol. 14, No. 2, pp. 123-142.

Brennan, J. and Shah, T. (2000), "Quality assessment and institutional change: experiences from 14 countries", Higher Education, Vol. 40, No. 3, pp. 331-349.

Cartwright, M.J. (2007), "The rhetoric and reality of 'quality' in higher education: an investigation into staff perceptions of quality in post-1992 universities" Quality Assurance in Education, Vol. 15, No. 3, pp. 287-301.

Cave, M., Hanney, S., Henkel, M. and Kogan, M. (1997), The Use of Performance Indicators in Higher Education: the Challenge of the Quality Movement, $\left(3^{\text {rd }}\right.$ ed.), Jessica Kingsley, London.

Grant, D., Mergen, E. and Widrick, S. (2004), "A comparative analysis of quality management in US and international universities", Total Quality Management, Vol. 15, No.4, pp. 423-438. 
Harvey, L. (2007), "Quality culture, quality assurance and impact. Overview of discussions", paper presented at: Embedding Quality Culture in Higher Education. A Selection of Papers from the $1^{\text {st }}$ European Forum for Quality Assurance, München, Germany, 23-25 November 2006, EUA, Brussels, pp.81-84.

Harvey, L. and Green, D. (1993), "Defining quality”, Assessment \& Evaluation in Higher Education, Vol.18, No.1, pp. 9-34.

Harvey, L. and Newton, J. (2004), "Transforming quality evaluation", Quality in Higher Education, Vol. 10, No. 2, pp. 149-165.

Harvey, L. and Newton, J. (2007), "Transforming quality evaluation: moving on", in Westerheijden, D.F., Stensaker, B. and Rosa, M.J. (Eds), Quality Assurance in Higher Education. Trends in Regulation, Translation and Transformation, Springer, Dordrecht, The Netherlands, pp. 225-245.

Harvey, L. and Stensaker, B. (2008). "Quality Culture: understandings, boundaries and linkages", European Journal of Education, Vol. 43, No. 4, pp. 427-442.

HBO-Raad, (2007), “Gemeenschappelijke Vragenlijst 'Pilot Landelijke Studentenenquête' [Shared Questionnaire 'Pilot National Student Survey'"], HBO-Raad, Den Haag, The Netherlands: internal note.

HBO-raad, (2009), "Feiten en Cijfers, Personeel in het Hoger Beroepsonderwijs [Fact Sheet, Employment in Universities of Applied Sciences]", HBO-Raad, Den Haag, The Netherlands, available at: http://www.hbo-raad.nl/hbo-raad/publicaties/cat_view/43-publicaties/40-2008 (accessed 1 July 2010).

HBO-raad. (2010). "The Netherlands Association of Universities of Applied Sciences", HBO-Raad, Den Haag, The Netherlands, available at: www.hbo-raad.nl/english (accessed 5 January 2011).

Hulpiau, V. and Waeytens, K. (2001), "Improving quality of education: what makes it actually work? A case study", paper presented at 'The International Research Conference 'Higher Education Close Up', Lancaster University, Lancaster, UK, 16-18 July, available at: http://www.leeds.ac.uk/educol/documents/00001810.htm (accessed I July 2010).

Knight, P.T. and Trowler, P.R. (2000), “Department-level cultures and the improvement of learning and teaching", Studies in Higher Education, Vol. 25, No.1, pp. 69-83.

Koch, J.V. (2003), "TQM: Why is its impact in higher education so small?", The TQM Magazine, Vol. 15, No. 5, pp. 325-333.

Lewis, R.G. and Smith, D.H. (1994), Total Quality in Higher Education, St, Lucie Press, Delray Beach, Florida.

Lomas, L. (2007), "Zen, motorcycle maintenances and quality in higher education", Quality Assurance in Education, Vol. 15, No. 4, pp. 402-412.

Martens, E. and Prosser, M. (1998), "What constitutes high quality teaching and learning and how to assure it?", Quality Assurance in Education, Vol. 6, No. 1, pp. 28-36.

Milliken, J. and Colohan, G. (2004), "Quality or control? Management in higher education", Journal on Higher Education Policy and Management, Vol. 26, No. 3, pp. 381-391.

Newton, J. (2000), “Feeding the beast or improving quality? Academics' perceptions of quality assurance and quality monitoring", Quality in Higher Education, Vol. 6, No. 2, pp. 153-163.

Newton, J. (2002), "Views from below: academics coping with quality", Quality in Higher Education, Vol. 8, No. 1, pp. 39-61.

Owlia, M.S. and Aspinwall, E.A. (1996), "Quality in Higher Education”, Total Quality Management, Vol. 7, No. 2, pp. 161-171.

Parasuraman, A., Berry, L.L. and Zeithameln, V.A. (1991), "Refinement and reassessment of the servqual scale", Journal of Retailing, Vol. 67, No. 4, pp. 420-450.

Rosa, M.J. and Amaral, A. (2007), "A self-assessment of higher education institutions from the perspective of the EFQM excellence model", in Westerheijden, D.F., Stensaker, B. and Rosa, M.J. (Eds), Quality Assurance in Higher Education. Trends in Regulation, Translation and Transformation, Springer, Dordrecht, The Netherlands, pp.181-207.

Sahney, S., Banwet, D.K. and Karunes, S. (2004), "Conceptualizing total quality management in higher education", The TQM Magazine, Vol. 16, No. 2, pp. 145-159. 
Sallis, E. (2002), Total Quality Management in Education, (3 ${ }^{\text {rd }}$ edn.), Kogan, London.

Segers, M.S.R. (1993), Kwaliteitsbewaking in het Hoger Onderwijs: een Exploratieve Studie naar Prestatieindicatoren in Theorie en Praktijk [Quality Assurance in Higher Education: an Explorative Inquiry into the Performance Factors in Theory and Practice], Universiteit Maastricht, Maastricht, The Netherlands.

Stensaker, B. (2006), "Impact of quality processes", paper presented at: Embedding Quality Culture in Higher Education. A Selection of Papers from the $1^{\text {st }}$ European Forum for Quality Assurance, München, 23-25 November, European University Association, Brussels, Belgium, pp. 59-62.

Van Damme, D. (2004), "Standards and indicators in institutional and programme accreditation in higher education: a conceptual framework and a proposal", in Vlasceanu, L. and Barrows, L.C. (Eds), Indicators for Institutional and Programme Accreditation in Higher/Tertiary Education, UNESCOCEPES,Bucharest, pp. 127-159.

Van der Zee, H. (1990), "Kwaliteitsverbetering en innovatiemanagement [Quality improvement and management of innovation]", Management en Organisatie, Vol. 44, No. 3, pp. 201-214.

Venkatraman, S. (2007), "A framework for implementing TQM in higher education programs", Quality Assurance in Education, Vol. 15, No. 1, pp. 92-112.

Vettori, O., Lueger, M. and Knassmüller, M. (2006). “Dealing with ambivalences - strategic options for nurturing a quality culture in teaching and learning", paper presented at: Embedding Quality Culture in Higher Education. A Selection of Papers from the $1^{\text {st }}$ European Forum for Quality Assurance, München, 23- 25 November, European University Association, Brussels, Belgium, pp. 21-33.

Vroeijensteijn, A.I. (1990), “Kwaliteitswaarborg door interne en externe kwaliteitszorg [Quality assurance through internal and external quality management]", In Heijnen, G.W.H., Joostens, T.H. and Vroeijensteijn, A.I. (Eds), Kwaliteitszorg, Waarborg voor Kwaliteit in het Hoger Onderwijs [Quality Management: Quality Assurance in Higher Education], COWOG, .Groningen, The Netherlands, pp. 273289.

Vroeijensteijn, A.I. (1995), Improvement and Accountability: Navigating between Scylla and Charybdis. Guide for External Quality Assessment in Higher Education, Jessica Kingsley Publishers, London and Bristol, Pennsylvania.

Watty, K. (2002), "Engaging grassroots academics in quality conversations and quality initiatives: opportunities lost?" Paper presented at International Conference on Transforming Quality: Seventh Quality in Higher Education International Seminar, 31 October - 1 November, Melbourne, Australia, available at: http://www.qualityresearchinternational.com/tq/papers/wattyoutline.doc.doc (accessed 1 July 2010).

Watty, K. (2006), "Want to know about quality in higher education? Ask an academic", Quality in Higher Education, Vol. 12, No. 3, pp. 291-301.

Weick, K. (1976), "Educational Organizations as loosely coupled systems", Administrative Science Quarterly, Vol. 21, No. 1, pp. 1-19.

Westerheijden, D.F. (1999), "Where are the quantum jumps in quality assurance? Developments of a decade of research on a heavy particle", Higher Education, Vol. 38, No. 2, pp. 233-254.

Westerheijden, D.F., Hulpiau, V. and Waeytens, K. (2007), "From design and implementation to impact of quality assurance: an overview of some studies into what impacts improvement", Tertiary Education and Management, Vol.13, No. 4, pp. 295-316.

Wiklund, H., Klefsjö, B., Sandvik Wiklund, P. and Edvardsson, B. (2003), "Innovation and TQM in Swedish higher education institutions - possibilities and pitfalls", The TQM Magazine, Vol. 15, No. 2, pp. 99107.

Yeo, R.K. (2008). "Brewing service quality in higher education. Characteristics of ingredients that make up the recipe", Quality Assurance in Education, Vol. 16, No. 3, pp. 266-286.

Zbaracki, M. J. (1998). "The rhetoric and reality of Total Quality Management", Administrative Science Quarterly, Vol. 43, No. 3, pp. 602-636. 


\section{Appendix 1. The 'quality management activities' scale (QMA)}

The following statements relate to the current state of affairs concerning internal quality management within your department. Internal quality management is defined as structured and systematic application of the plan/do/check/act cycle (PDCA).

To what extent do you agree with the following statements?

\begin{tabular}{|c|c|c|c|c|c|}
\hline Statements* & $N$ & Min & Max & Mean & $S D$ \\
\hline \multicolumn{6}{|l|}{ Subscale 1. PDCA (Plan, do, check, act) } \\
\hline \multicolumn{6}{|l|}{80 Criteria and standards for the relevant educational processes are } \\
\hline described adequately. & 256 & 1.00 & 5.00 & 3.21 & 1.02 \\
\hline \multicolumn{6}{|l|}{82 Criteria and standards for the relevant conditional managerial } \\
\hline processes are described adequately. & 214 & 1.00 & 5.00 & 2.82 & 0.98 \\
\hline \multicolumn{6}{|l|}{81 Criteria and standards regarding the relevant support processes } \\
\hline are described adequately. & 228 & 1.00 & 5.00 & 3.02 & 0.98 \\
\hline \multicolumn{6}{|l|}{$\begin{array}{l}86 \text { Quality management systematically leads to modification, im- } \\
\text { provement or innovation of education, when this is considered }\end{array}$} \\
\hline desirable or necessary. & 244 & 1.00 & 5.00 & 3.36 & 1.06 \\
\hline \multicolumn{6}{|l|}{84 The results of quality assessment are regularly compared with } \\
\hline those of other departments. & 197 & 1.00 & 5.00 & 2.91 & 1.04 \\
\hline \multicolumn{6}{|l|}{85 Quality management (PDCA) is part of the normal working prac- } \\
\hline tices of all staff-members in the department. & 240 & 1.00 & 5.00 & 3.00 & 1.14 \\
\hline \multicolumn{6}{|l|}{83 The results of evaluations are systematically compared with the } \\
\hline described criteria or standards. & 208 & 1.00 & 5.00 & 3.00 & 1.00 \\
\hline \multicolumn{6}{|l|}{ Subscale 2 External evaluation and communication } \\
\hline \multicolumn{6}{|l|}{74 The frequency and number of quality evaluations among alumni } \\
\hline \multicolumn{6}{|l|}{78 There is sufficient communication with alumni about the results of } \\
\hline \multicolumn{6}{|l|}{73 The frequency and number of quality evaluations in the field and } \\
\hline \multicolumn{6}{|l|}{77 There is sufficient communication with the field and the profes- } \\
\hline \multicolumn{6}{|l|}{ Sub-scale 3 Internal evaluation and communication } \\
\hline \multicolumn{6}{|l|}{72 The frequency and number of quality evaluations among students } \\
\hline are sufficient. & 258 & 1.00 & 5.00 & 3.80 & 1.02 \\
\hline \multicolumn{6}{|l|}{79 There is sufficient communication with teachers about evaluation } \\
\hline results and potential improvements. & 257 & 1.00 & 5.00 & 2.99 & 1.05 \\
\hline \multicolumn{6}{|l|}{76 There is sufficient communication with students about evaluation } \\
\hline results and potential improvements. & 252 & 1.00 & 5.00 & 3.00 & 1.06 \\
\hline \multicolumn{6}{|l|}{ Additional } \\
\hline $\begin{array}{l}75 \text { The frequency and number of evaluations among teachers are } \\
\text { sufficient. }\end{array}$ & 254 & 1.00 & 5.00 & 2.94 & 1.13 \\
\hline $\begin{array}{l}87 \text { The department's external communication about the achieved } \\
\text { quality results is open and honest. }\end{array}$ & 231 & 1.00 & 5.00 & 3.53 & 1.03 \\
\hline
\end{tabular}

\footnotetext{
* The (sub)scales had to meet minimal numbers of filled in items.
} 


\section{Appendix 2. The 'attention to quality aspects' scale (AQA)}

The following statements relate to different aspects of educational quality. Some of these aspects are comprehensive and complex. You are asked to indicate whether within your department sufficient attention is given to the totality of the aspects.

To what extent do you agree with the following statements?

\begin{tabular}{|c|c|c|c|c|c|}
\hline Statement* & $\boldsymbol{N}$ & Min & Max & Mean & $S D$ \\
\hline \multicolumn{6}{|l|}{ Subscale 1. Teaching and learning } \\
\hline $\begin{array}{l}55 \text { The department pays sufficient attention to programme content } \\
\text { (level, up-to-date, coherence, electives). }\end{array}$ & 262 & 1.00 & 5.00 & 3.41 & 1.046 \\
\hline $\begin{array}{l}67 \text { The department pays sufficient attention to competency level } \\
\text { attained by graduates. }\end{array}$ & 257 & 1.00 & 5.00 & 3.44 & 0.963 \\
\hline $\begin{array}{l}57 \text { The department pays sufficient attention to the educational } \\
\text { process (in particular methods of instruction and tutoring). }\end{array}$ & 260 & 1.00 & 5.00 & 3.50 & 1.027 \\
\hline $\begin{array}{l}56 a \text { The department pays sufficient attention to professional orienta- } \\
\text { tion (practice oriented educational programmes, preparation for } \\
\text { professional practice, contacts with professional practice, practical }\end{array}$ & & & & & \\
\hline experiences, internships). & 261 & 1.00 & 5.00 & 3.76 & 1.022 \\
\hline $\begin{array}{l}64 \text { The department pays sufficient attention to evaluation and as- } \\
\text { sessment processes (assignments, papers, tests, exams) }\end{array}$ & 261 & 1.00 & 5.00 & 3.44 & 0.933 \\
\hline $\begin{array}{l}65 \text { The department pays sufficient attention to study load (appropri- } \\
\text { ate, doable within four years, workload is evenly distributed over the }\end{array}$ & & & & & \\
\hline year). & 258 & 1.00 & 5.00 & 3.43 & 0.936 \\
\hline 56b The department pays sufficient attention to international aspects & & & & & \\
\hline of the programme and the profession. & 261 & 1.00 & 5.00 & 3.26 & 1.046 \\
\hline $\begin{array}{l}66 \text { The department pays sufficient attention to external information } \\
\text { to employers, the profession, alumni, companies/institutions offering } \\
\text { traineeships. }\end{array}$ & 256 & 1.00 & 5.00 & 3.32 & 0.919 \\
\hline 58 The department pays sufficient attention to teachers' professional & & & & & \\
\hline and educational skills. & 260 & 1.00 & 5.00 & 3.22 & 1.038 \\
\hline
\end{tabular}

\section{Subscale 2. Information and facilities}

61 The department pays sufficient attention to informing students about the content of the programme, regulations and procedures and study progress.

60 The department pays sufficient attention to entering students (information, coaching, exemptions and admission procedures).

62 The department pays sufficient attention to informing students about time schedules for courses and exams and any changes in schedules.

63 The department pays sufficient attention to facilities and provisions (information desk, student administration, library, classrooms, ICT and canteen facilities).

59 The department pays sufficient attention to accessibility of teachers and student-teacher communication.

\section{Subscale 3. Results}

70 The department pays sufficient attention to its place in national 
and international rankings.

68 The department pays sufficient attention to the percentage of graduating students.

69 The department pays sufficient attention to the position of gradu-

ates in the labour market.

$\begin{array}{lllll}256 & 1.00 & 5.00 & 3.23 & 1.014\end{array}$

* The (sub)scales had to meet minimal numbers of filled in items

\section{Appendix 3. Two effectiveness scales: 'perceived improvement' and 'perceived control'}

The final statements address the question whether within your department internal quality management is or is not effective.

To what extent do you agree with the following statements?

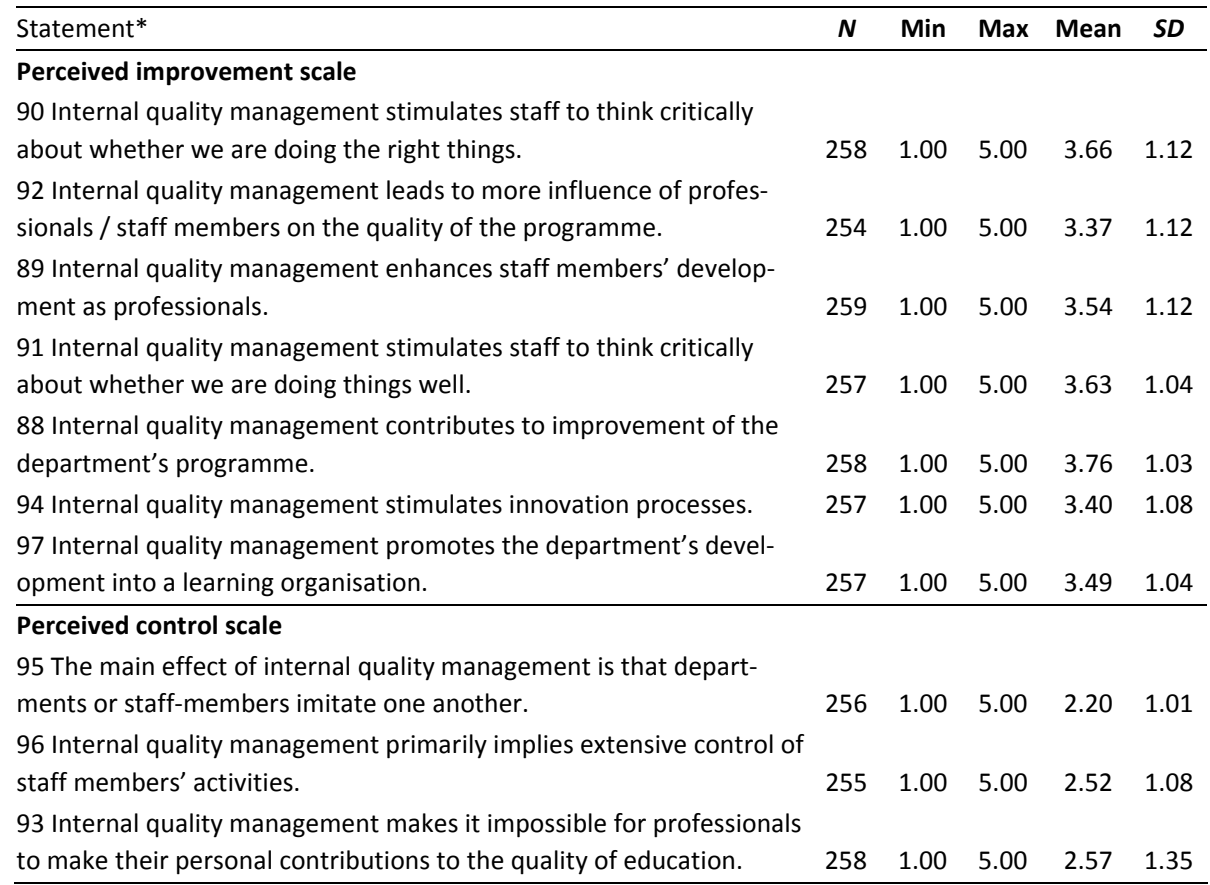

* The scales had to meet minimal numbers of filled in items 


\section{Chapter 6}

\section{Effective quality management requires a systematic approach and a culture of flexibility and open communication}

A qualitative study on conceptions, perceptions and values of academic staff in higher education ${ }^{4}$

\footnotetext{
${ }^{4}$ Submitted:

Kleijnen, J.C.B.M. ., Dolmans, D.H.J.M., Willems. J.M.H.M. \& Van Hout, J.F.M.J.
} 


\begin{abstract}
This study examines the similarities and differences between three teaching departments within Universities of Applied Sciences (UAS) in the Netherlands that provide effective and three that provide less effective quality management. What are staff members' conceptions and perceptions of quality, quality management and organisational values and how do they connect? Per department three semistructured interviews were conducted. Within all departments the conceptions of quality and the preferred organisational values are quite similar: quality is seen as continuous improvement of education and human relations values are preferred. The differences concern practice. Effective departments have a structured quality management that is closely connected with day-to-day work and results in improvements. These departments realise the organisational values they prefer. The recommendation is to work on a culture that involves cooperation, open communications, flexibility and external orientation, and the close involvement of quality management in the regular work of staff.
\end{abstract}

Key words: conceptions of quality; quality management; effectiveness of quality management; organisational culture; flexible organisational values. 


\section{Introduction}

Some authors claim that internal quality management has significant positive effects, such as increased involvement of all parties, the strengthening of team work and of the professional skills of teaching staff and the improvement of education and teaching processes (Brennan and Shah 2000; Westerheijden et al. 2007; Stensaker 2006). Other authors emphasise, however, the negative effects of quality management, such as paying excessive attention to 'external control' and 'accountability', an exaggerated bureaucracy and an attack on the professional autonomy of teaching staff (Watty 2002; Milliken and Colohan 2004; Cartwright 2007). Somebody's judgment on the effectiveness of quality management depends not only on the way in which this quality management is performed, but is also linked to his conceptions of the quality of education (Gibson 1986; Newton 2000; Cruickshank 2003; Houston 2008, Lanarès 2008)). This conception may vary according to the interests and priorities of the different stakeholders: What do they think are the goals of a university? What are the right things for the university to do to achieve these goals and the right ways of doing them (Gibson 1986; Houston 2008)? According to literature, these conceptions of quality and the judgements on the effectiveness of quality management are embedded in the culture of an institution and especially in its organisational values (Harvey and Green 1993; Cameron and Quinn 1999; Kezar and Eckel 2002). Frequent reference is therefore made to a quality culture (Yorke 2000; EUA 2006; Harvey and Stensaker 2008; Lanarès 2008). This article explores in a qualitative empirical manner the quality culture by investigating the quality conceptions of senior staff members in higher education, their perceptions of quality management and the organisational values they prefer and experience in daily practice.

This qualitative investigation amongst senior staff in higher education utilises the research framework shown in Figure 1. The upper part of the framework focuses on the preferred values within the organisation and on staff's conceptions of what quality of education means. These values and conceptions have no direct influence upon perceptible behaviour, since there is often a gap between the values and conceptions that people prefer or espouse (espoused theory) on the one hand, and the values and conceptions that are apparent from their actual behaviour (theory in practice) on the other hand (Brunsson 1989; Argyris 1990; Cameron and Quinn 1999). Because of this gap, the lower part of the framework focuses on staff's perceptions of practice; i.e. the organizational values they experience in the daily practice of their departments and their perceptions of the performance and effectiveness of quality management. These variables are placed within the context of the teaching department. 


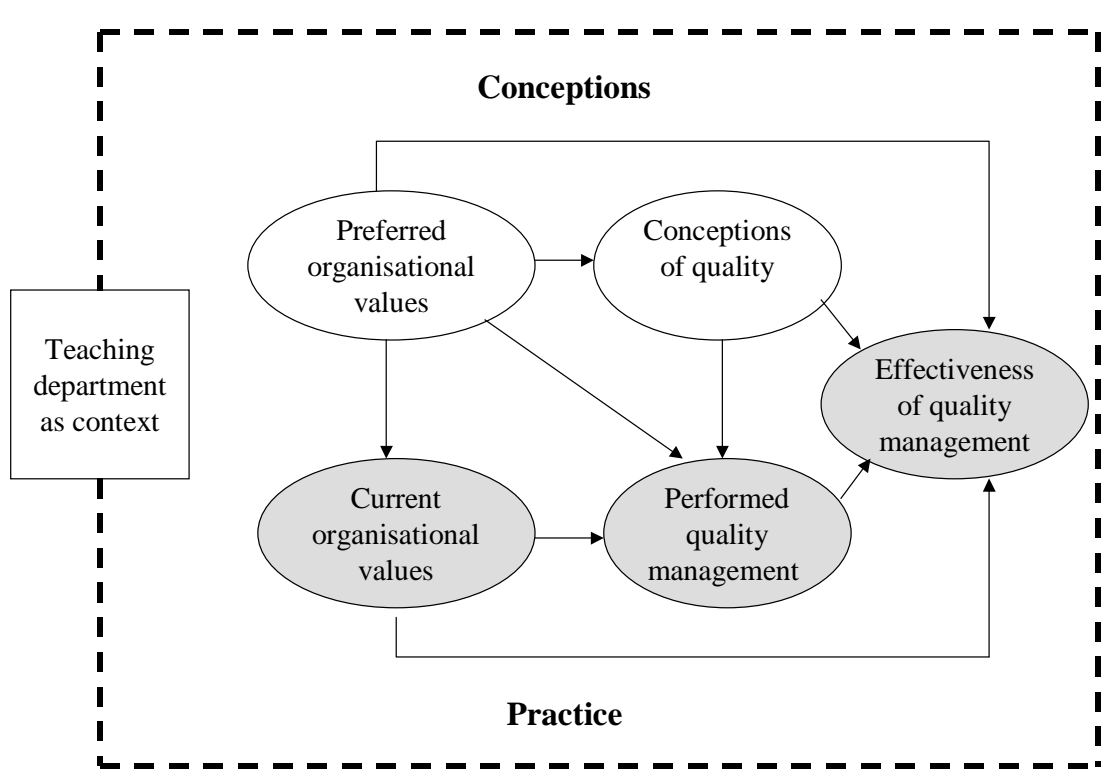

Figure 1. Research framework: conceptions and practice within teaching departments

In a previous study carried out in 2008 the authors performed a quantitative survey amongst 266 teachers at eighteen teaching departments of higher education institutes (Kleijnen et al. 2009 and 2011). In that research significant differences between teaching departments were found in the effectiveness of quality management. The goal of this qualitative research amongst senior staff members is to gain a deeper understanding of the differences between teaching departments having an effective and a less effective quality management. There are two research questions. The first: what are the similarities and differences between departments providing effective and less effective quality management? Attention is focused here on the conceptions and perceptions of senior staff regarding quality, quality management and organisational values. The second: what are the relationships between these conceptions and perceptions and does this further the understanding of the differences between departments providing effective and less effective quality management?

\section{Method}

\section{Participants}

During the months of June to September 2010 three oral interviews were conducted within six teaching departments of Universities of Applied Sciences (UAS) in the Netherlands: one with the manager/director of the department, and two with 
senior teaching staff. The selection of these six departments was based on the method of 'typical cases' with 'maximum variation,' aiming for "as wide a range of perspectives as possible to capture the broadest set of information and experiences" (Kuper et al. 2008, p. 688). The earlier quantitative research of eighteen teaching departments $(N=266)$ had revealed that three departments demonstrated an effective and three a less effective internal quality management (Kleijnen et al. 2011). This was measured according to their score on a five-point Likert scale: 'Perceived Improvement' (PI). The three effective departments are 06 (health care), 05 (health care) and 09 (education). The average scores for these departments for 'Perceived Improvement' were: $M=4.25$ ( $S D=0.56, N=22), M=4.06$ (SD = 0.55 $N=11)$ and $M=3.98(S D=0.62, N=16)$, respectively. The three less effective departments are 08 (health care), 15 (engineering) and 13 (social welfare). The average scores for these departments for 'Perceived Improvement' were: $M=3.36$ (SD = $0.90, N=17), M=3.03(S D=0.88, N=13)$ and $M=2.93(S D=1.12, N=30)$.

\section{Design and instrument}

This qualitative research offers an opportunity for triangulation (Flick 1992). Here it is applied to test and adjust or refine the deductively drafted and quantitatively researched theoretical framework of Figure 1 (Lingard et al. 2008). It complements, illustrates and clarifies the quantitative results by providing examples. The interviews were conducted with the help of eight semi-structured questions. The partial structuring ensured that the focus of the interviews was on the subjects that were significant to the research and that the respondents were free to give their own answers. The questions were directed towards the following subjects: 1) the conceptions of the respondents about the quality of education; 2) their perceptions of internal quality management within their departments; 3 ) their perception of its effectiveness; 4) the organisational values that the respondents regard as preferable and 5) their perception of these values in day-to-day practice.

\section{Processing and analysis}

The eighteen interviews were electronically recorded and extensive written summaries were taken of these recordings, which were then sent to the respondents for their approval. Seventeen of the respondents indicated their approval and a number of them suggested some changes. The eighteenth respondent indicated she was unable to respond due to time constraints. The reports were analysed per department with the aid of the themes contained in the theoretical framework (Figure 1). The descriptive analysis was based on an intensive study of the reports, and the answers to questions were recorded per category. Where required, categories were added or refined. The summaries of three of the six departments were categorized 
by the first author and by another researcher in order to check whether interpretations were in line with one another. The 'typical case' results of department 06, having the highest score for 'perceived improvement', and department 13, earning the lowest score, were then compared with each other; the similarities and differences were recorded by theme in tables and the findings were looked at to see if they also applied to the other departments. Relationships were then sought between the different variables and the question was addressed as to whether the theoretical model is appropriate for the qualitative data obtained (Pope and Mays 2009).

To classify and examine further the organisational values, this paper adopts the 'competing values framework' of Cameron and Quinn (1999) and Quinn et al. (2007). This framework is built on a long tradition of organisational theory and has been amply validated (Howard 1998; Cameron and Quinn 1999; Patterson et al. 2005). The framework is a two-dimensional model. The first dimension is related to competition between internal and external orientation, the second deals with the tension between control and flexibility. These two dimensions result in four quadrants, each quadrant representing an ideal type of values (Cameron and Quinn 1999). Thus the framework consists of two control-oriented value orientations: the rational goal model (RG) with an external focus and with the main values of planning, efficiency, goal setting and adherence to agreements, and the internal process model (IP) with an internal focus and the main values of stability, control, measurement and information management. In addition, the framework comprises two flexibility-oriented organisational values: the human relations model (HR) with an internal focus and with the main values of participation, involvement, cohesion and openness and the external open system model (OS) with values such as flexibility, willingness to change, growth and resource acquisition.

\section{Results}

\section{Effectiveness of quality management}

In the case of effective teaching departments, quality management leads often to improvements and innovations (Table 1). These are mostly not solely based on low or high scores from written questionnaires but also on in-depth analysis and fundamental insights into the strengths and weaknesses of the curriculum that are revealed. In addition respondents mention effects of improving processes of learning, a more active involvement of students and the external professional working field and sometimes even of higher achievement levels of graduates. "Quality management contributes enormously to the quality of education. Because I can see how it brings about changes, and that there is often new input and that innovations in 
the development of the profession are taken into account and are a part of education. This is only possible if you remain alert and the external working field is involved."(6-1: department 6 , respondent 1$)$. In these departments, quality management leads to satisfied students who receive timely and adequate responses to their requirements and questions: "They see that they are being listened to, that their opinions count. This results in an improved atmosphere, which directly benefits education" (6-3). Finally, according to the respondents, quality management also contributes to greater compliance with external standards and expectations.

Table 1. Effectiveness and effects of quality management: differences between effective and less effective departments

\begin{tabular}{|c|c|}
\hline $\begin{array}{l}\text { Departments with the most effective quality } \\
\text { management }\end{array}$ & $\begin{array}{l}\text { Departments with the least effective quality } \\
\text { management }\end{array}$ \\
\hline Innovation of the curriculum & Only a limited improvement to the curriculum \\
\hline $\begin{array}{l}\text { In-depth analysis of strengths and weaknesses of the } \\
\text { curriculum, not based solely on indications } \\
\text { from evaluations }\end{array}$ & $\begin{array}{l}\text { In-depth analysis is lacking but there is some } \\
\text { understanding of the deficiencies }\end{array}$ \\
\hline $\begin{array}{l}\text { Improvement of learning processes and of the } \\
\text { achievement level of graduates }\end{array}$ & Hardly any improvements in learning processes \\
\hline $\begin{array}{l}\text { Active involvement of students and the external } \\
\text { professional working field }\end{array}$ & $\begin{array}{l}\text { Little involvement of students and external working } \\
\text { field }\end{array}$ \\
\hline Good communication with students, fast feedback & $\begin{array}{l}\text { Insufficient communication with/feedback to } \\
\text { students }\end{array}$ \\
\hline The study programme meets external standards & Meeting external standards is not cited as an effect \\
\hline
\end{tabular}

In the case of the least effective departments, the respondents have doubts about the effectiveness of quality management: "If you are talking about real quality management then this is a matter of evaluations and revisions. How are these revisions carried out? . . Actually quality management does not make a specific contribution to them. This has got me thinking." (13-2). In the case of another rather ineffective department a respondent says: "Well, that surely should be done better. The system is in place. We have a cycle: pdca. It's in place - plan, do, check. . . . But communications are a different matter. If we improve things, we fail to communicate this adequately or at all to the students and to teaching staff. Thus we change things. But is this really an improvement?" (8-3). Nevertheless, even in the case of the less effective departments, people recognise some positive effects. A respondent from department 15 comments about quality management regarding testing: "But I do see that these checks do eliminate the big errors: errors of content, grammatical errors or errors in counting scores. They could be really simple things. But it may also happen that a colleague asks you: is this really what we created this programme module for? Then you find yourself asking a kind of question in the test that is different from the ones intended by the module" (15-2). 


\section{Conceptions of quality}

The respondents within both the effective and the less effective departments associate the term "quality" mainly with the primary process of teaching and learning. They think of the goals of the study programme, its content, the methods, an appropriate level of self-guidance by students, professional teaching staff and a challenging learning environment.

The way in which the respondents look at improvement and innovation also reveals many similarities. Within all departments, respondents think that quality implies that the department must focus on continuous improvement and innovation. External standards and regulations play a part here and focus direction, especially within department 15 (engineering), but focusing on standards is not in itself enough. The standards must be interpreted and given substance by the department. This view prevails within all departments, but receives greater emphasis within the more effective ones. Nevertheless, it is also widely pointed out that changes need time to flourish and mature and that continuous improvement is not the same as continuous change. "Every innovation requires time to implement, to enable people to deal flexibly with it and to find yielding solutions for the limitations it imposes ... The problem always lies with the switch to a new system. . . Discovering the opportunities and how to deal with any limitations is a gradual process. Then the system becomes complete and complex once more" (6-3).

There are also some differences, however, between effective and less effective departments. For example, within department 15 (engineering) staff see quality of education, more than in other departments, as structure, consistency and predictability, and as sustainability of improvements over the long term. However, the most important difference is internal consensus. Surely, there are differences in vision within all departments: regarding the identity and role of the teacher as responsible for a particular subject or as being responsible for the study programme as a whole, regarding the correct mix of supervision and self-study, the demanded level of achievement of students, or the degree of self-evaluation and self-reflection one can expect from students at graduation. In the case of effective departments, these differences have a stimulating effect: "The differences that exist always result in a huge amount of talk - but that is normal. But they also result in new developments. The discussion is not about being proved right, but about improving things. This attitude is important" (6-3). Within less effective departments, however, the differences remain implicit: "Each person has an idea of what he or she regards as quality. But do these ideas overlap very much? It's hard to say. I think they do, but we actually don't know, because we talk so little about the substance of these things. Often they are left as abstract ideas and nothing concrete comes from them, and then we don't know if we are talking about the same things or not" (13-3). These less effective departments reveal a considerably less amount of fruitful discussion. 


\section{Internal quality management}

In almost all departments various quality instruments are regularly applied. Most departments work with policy plans or annual plans, consultative meetings regarding vision and policy, procedures and criteria for designing and carrying out programmes and assessment, evaluations amongst students, teaching staff and the external working field and job performance or assessment interviews. There is often a person whose job it is to focus on quality management. Furthermore, within most departments, the teaching staff are more or less familiar with the existence of quality management and the instruments deployed (Table 2).

Table 2. Internal quality management: similarities and differences between effective and less effective departments

\begin{tabular}{ll}
\hline $\begin{array}{l}\text { Departments with the most effective quality } \\
\text { management }\end{array}$ & $\begin{array}{l}\text { Departments with the least effective quality } \\
\text { management }\end{array}$ \\
\hline
\end{tabular}

The departments apply various quality instruments:

- There are policy plans and/or annual plans and annual reports

- Consultative meetings, referral sessions and meetings concerning vision and policy are organised

- Procedures and criteria for designing and executing study programmes, modules and assessment

- Evaluations amongst students, teaching staff and the external working field

- Quality instruments regarding personnel: performance and assessment interviews etc.

There is often a person in charge of quality and quality management or with a portfolio for promoting quality

Teaching staff are more or less familiar with quality management

\begin{tabular}{|c|c|}
\hline $\begin{array}{l}\text { Clear, quality objectives for the study programme, a } \\
\text { clear, common vision }\end{array}$ & Unclear quality objectives \\
\hline \multicolumn{2}{|c|}{$\begin{array}{l}\text { Reflection upon the results of evaluations, considering Insufficient reflection upon the evaluations } \\
\text { the results of related evaluations }\end{array}$} \\
\hline Evaluations lead to improvements plans & $\begin{array}{l}\text { Little relationship between evaluations and meas- } \\
\text { ures of improvement }\end{array}$ \\
\hline Practicable annual plans or policies & Little operational annual plans or policies \\
\hline $\begin{array}{l}\text { Implementation of improvements/innovations is } \\
\text { monitored }\end{array}$ & Inadequate monitoring \\
\hline Completed pdca cycle & Pdca cycle incomplete \\
\hline Commitment and active participation of most staff & $\begin{array}{l}\text { Limited commitment, little active participation. } \\
\text { Support is dependent on pressure from manage- } \\
\text { ment and external standards }\end{array}$ \\
\hline $\begin{array}{l}\text { Quality management is a structural element of the } \\
\text { usual work/tasks of all staff }\end{array}$ & $\begin{array}{l}\text { Quality management is too complicated and } \\
\text { mostly a matter for quality management staff }\end{array}$ \\
\hline Bureaucratic paperwork is limited & $\begin{array}{l}\text { Quality management is mostly just consigned to } \\
\text { paper }\end{array}$ \\
\hline $\begin{array}{l}\text { Clear responsibilities; a sense of shared responsibili- } \\
\text { ties. It is clear who monitors this }\end{array}$ & $\begin{array}{l}\text { Pushing responsibilities aside. } \\
\text { Unclear as to who monitors this }\end{array}$ \\
\hline $\begin{array}{l}\text { Effective formal and informal communication } \\
\text { Consultations held to arrive at consensus }\end{array}$ & Inadequate formal and informal communication \\
\hline
\end{tabular}


There are nevertheless big differences between the effective and less effective teaching departments (Table 2). In the case of effective departments, the policy plans, procedures, criteria and other instruments are based on clear quality objectives for the study programme, such as the focus on professional competencies, a wide or narrow professional profile, greater supervision at the start and greater self study towards the end of the study programme. Less effective departments lack this joint vision. In the case of effective departments, evaluations frequently lead to a structured reflection and analysis, considering related evaluations as well, to feasible plans and proposals for improvements and to communication and feedback. The teaching staff here may not be just familiar with quality management and intentions to improve, but they may also demonstrate commitment and active participation, whereby quality management is spontaneously implemented: "You can't avoid it, but nor is it forced upon you. It's simply part of the job, just like the fact that you turn up for lessons on time, tables are arranged, the blackboard is clean and tests have been looked at in time" (5-2). Quality management is a close partner of ordinary, day-to-day work. "It's all logical. Without any evaluation, the education is not complete .. . Everyone contributes to discussion forums, to reference meetings. Everyone is engaged in the design and implementation of study programmes, in evaluations and in making adjustments in response to these evaluations" (5-2). Responsibilities are mostly clear and communication is organised as efficiently as possible. Committees work with short, to-the-point reports and 'linking pins' ensure a smooth transfer of information. Differences of opinion lead to discussions focused on obtaining consensus and often also to intervision and training. Discussions are taken seriously and lead to concrete steps and policy decisions.

In the case of departments with the least effective quality management, the quality objectives are unclear. "The culture here is that the faculty sets out a few generalities such as 'being proactive', 'inspiration giving', 'enthusing others' and 'energising' but they don't help me. I want to know: what do they actually mean? That is not made tangible." (13-2). The system exists mostly on paper and the support of teaching staff often depends upon the pressure exerted by the management. Quality management is something that exists outside, rather than forms part of, one's day-to-day work. "We have also formulated quality criteria governing the modules. . . It looks fine on paper. A lot of time has been invested in it. Then it gets pushed to the back of a drawer." (13-3). There is little coherence between the evaluations, and the pdca cycle is not monitored. "There is little that is actually established: what input is expected from the students, what from the teaching staff? What does it mean in concrete terms? Where will we introduce changes? Where perhaps not yet? These different opinions must be brought together. . . Actually, the entire pdca cycle is unclear. Often, adjustments are delayed for a long time, often up to just ten weeks before the start of the new module. By then we've forgotten what opinions the students gave or they can't find the answers."(13-3). For this 
department it is also pointed out that work and responsibility for quality management are pushed onto the quality management portfolio holders. "In the past we worked with staff having those functions, quality management portfolio holders. But for all sorts of reasons, this achieved little. . . . A lot of work was pushed onto them, even at the time of implementation. They were rarely seen as people able to offer support. There was little attention paid to this, including by the management board" (13-3). As a possible reason for this it was mentioned that the quality management was a too complicated set-up. Too much was planned, and too little systematically carried out.

\section{Preferred organisational values}

This section looks at the values that the respondents prefer. The results reveal that the respondents within all teaching departments, including the most and least effective ones, have a substantial preference for the flexible human relations values. They emphasise collaboration, a feeling of joint responsibility, mutual inspiration, involvement with each other and with the department, and having regard for those with whom you have to work. "Colleagues should inspire each other. We should get together to discuss what we want from the education. How can we give substance to these goals? How satisfied are we with the results? We have to take our colleagues seriously. . . we must really listen to each other. We must also listen to students. If five of the 60 students participate in the evaluation you shouldn't dismiss them as being unrepresentative, but instead deal seriously with their comments" (13-3). It's not just about communication but also about a preferred practice of collaboration: "Inter-collegiate assessment and intervision. Good opportunities for collaboration between teachers, because an island culture is fatal for a quality culture" (13-1). This requires a safe climate: "The way in which we help each other, try to enthuse and motivate each other. Security means also that people should be allowed to make mistakes ..." (6-1). According to a number of respondents the management board may set an inspiring example by making itself open to criticism.

The preference for open system values is less dominant and is expressed mainly by respondents from the effective departments. The issue here is about dynamism, the willingness to take steps, to be enthusiastic and to want to excel. Dynamism is therefore preferred to continuity: "Continuous change is the constant factor. Stability must exist within a continuous adjustment to the changing environment "(9-2). External focus, the bringing in of the outside world and representing the department externally, is regarded as important for all departments, but within the least effective department people are not yet aiming at this. "I don't explicitly refer to openness to the profession and to the external working field, because the department itself is still undergoing organisational change. If you focus outwards and inwards right now, you don't achieve anything from either" (13-2). Finally, also con- 
trol-oriented organisational values, rational goal values, such as purposefulness and responsibility for results, and internal process values, such as stability and continuity, are mentioned within most departments. The preference for these, however, is rarely the dominant preference.

\section{Current organisational values}

In contrast to the preferred values, the teaching departments with the most and least effective quality management differ substantially from each other in the values that have been realised in practice (Table 3). In the case of the effective departments, the preferred organisational values and especially the human relations values are often put into practice. Teaching staff here work together, feel jointly responsible, inspire each other and feel involved both with each other and with the department. "Via short communication lines we tell each other what we think of it, even if mistakes are made. And sometimes it causes clashes and is also sometimes emotional. There must be room for this. You have to be able to look each other straight in the eye" (6-1). This is not to say that these values are one hundred percent realised: "Openness in the sense of pointing out mistakes to each other - that's more difficult" (5-1).

Within the less effective departments there is a clear gap between the human relations values deemed preferable and the values that are implemented in practice. This gap is very wide for the department with the least effective quality management. There are two subcultures: "There are groups of teachers for certain modules. You choose for yourself who the teachers are whom you like and whom you don't like and who fit in with your module and vice versa. This is how you organise the results of your own 360 feedback" (13-2). "There are informal contacts between the teachers. It's not that they meet each other in the staff room. But they do meet in the corridors. Then they talk about each other more than they talk to each other. This isn't a good thing. There is no habit of addressing each other directly with criticisms. There is also little praise expressed for each other" (13-3). 
Table 3. Current organisational values: differences between effective and less effective departments

\begin{tabular}{ll}
\hline $\begin{array}{l}\text { Departments with the most effective quality } \\
\text { management }\end{array}$ & $\begin{array}{l}\text { Departments with the least effective quality } \\
\text { management }\end{array}$
\end{tabular}

\section{Human relations values (frequently mentioned)}

- Collaboration, feeling of joint responsibility, inspiring each other, involvement with each other and with the department

- Good collegiate atmosphere, togetherness, work satisfaction, a good atmosphere for students

- Open to criticism, vulnerability, holding each other accountable, constructive criticism, praise for each other, trust and integrity

- Short communication lines, proximity, informal contacts

- Difference in opinion leads to discussion and learning, openness to good examples, being a learning organisation

- Teaching staff support students, connection with young people, willingness to talk with students

- Self reflection

- Little hierarchical etiquette, values and culture grow from the ground up

Open system values (less frequently mentioned)

- Dynamic

- Willingness to take steps to continually improve

- Enthusiasm, desire to excel, to distinguish oneself, to have pleasure in learning from experiences, addressing issues

- External orientation

- Willing and able to represent the department externally, to present the vision externally

- Balance between stability and change

\section{Rational goal values (seldom mentioned)}

- Making and carrying out agreements, goaloriented, responsibility for results

- Making choices, realistic ambitions
- Little collaboration, little involvement with each other

- Poor school atmosphere

- Little communication and openness, feeling of insecurity

- Sub-groups, no direct contact between people on the issue of performance.

- People often talk about each other instead of to each other

- Insufficient critical self reflection

- Decisions are taken, or are perceived to be taken, at the top

- Little willingness to take steps

- Proposals for improvements are treated with suspicion

- Dominant internal orientation
- Abandoning existing agreements. Agreements are mostly left on paper.

- Pushing responsibilities to one side

- Plans for improvement regarded as unachievable
Internal process values (seldom mentioned)

- Strong organisation, clear tasks, authorities, responsibilities, transparency of decision-taking
- Weak organisation. Less effective decisiontaking

Important values of the open system model are also made concrete within the effective departments. The respondents indicate that teaching staff wish to distinguish themselves and to excel and take pleasure in learning and developing. They are willing to actively contribute to improvement and innovation. "We are actually looking for change. . . . There are many opportunities and for me development 
can't happen fast enough" (5-3). "The processes of stability and development are there, but they grow on the work floor upwards. They are not imposed from the top down. We develop these processes together as an on-going process and take it further. . . ." (6-1). Effective departments are clearly externally-oriented. Teaching staff are willing and able to represent the department externally, to express its vision and to follow developments in working practice and to translate them into educational content. "For me, it's something that's natural. We are constantly seeking feedback from the outside world" (9-2). Within the less effective departments the external orientation is limited: "The outward vision and strategic vision was much less apparent, so it seemed. The inward vision, whether things are going well, that's first instincts" (8-3).

Rational goal and internal process values are less dominant and are mentioned mostly in terms of complaints. This is especially true in the case of the less effective departments. According to one respondent: "staff members frequently wish to backtrack on agreements" (13-2). Another respondent states: "Yes, we make agreements. But making sure that each other sticks by the agreements and monitoring the agreements . . . the system is set out on paper but we just don't follow it"(82). Within some departments, and especially the less effective ones, there are complaints that in policy formation too few choices are made and that ambitions are cherished that are unrealistic.

As reasons for this gap between preferred and current values within the less effective departments staff members frequently refer to internal or external developments or to structural characteristics of their departments. Examples include recent mergers, reorganisations or major curriculum changes, an unexpected growth or decline of student numbers, a management that makes too few choices, insufficient concrete or theoretical opportunities for the selection or education of staff or inadequate accommodation and facilities.

\section{Relationships between variables}

This study demonstrates that staff members' conceptions of quality and of preferred values are virtually the same within all departments. The differences between effective and less effective departments are related to their perceptions of current practice. Quality management is perceived as effective if it is systematically implemented in the departments and if the preferred organisational values are experienced in day-to-day practice. The adjustment of the research framework in Figure 2 further illustrates this connection. 


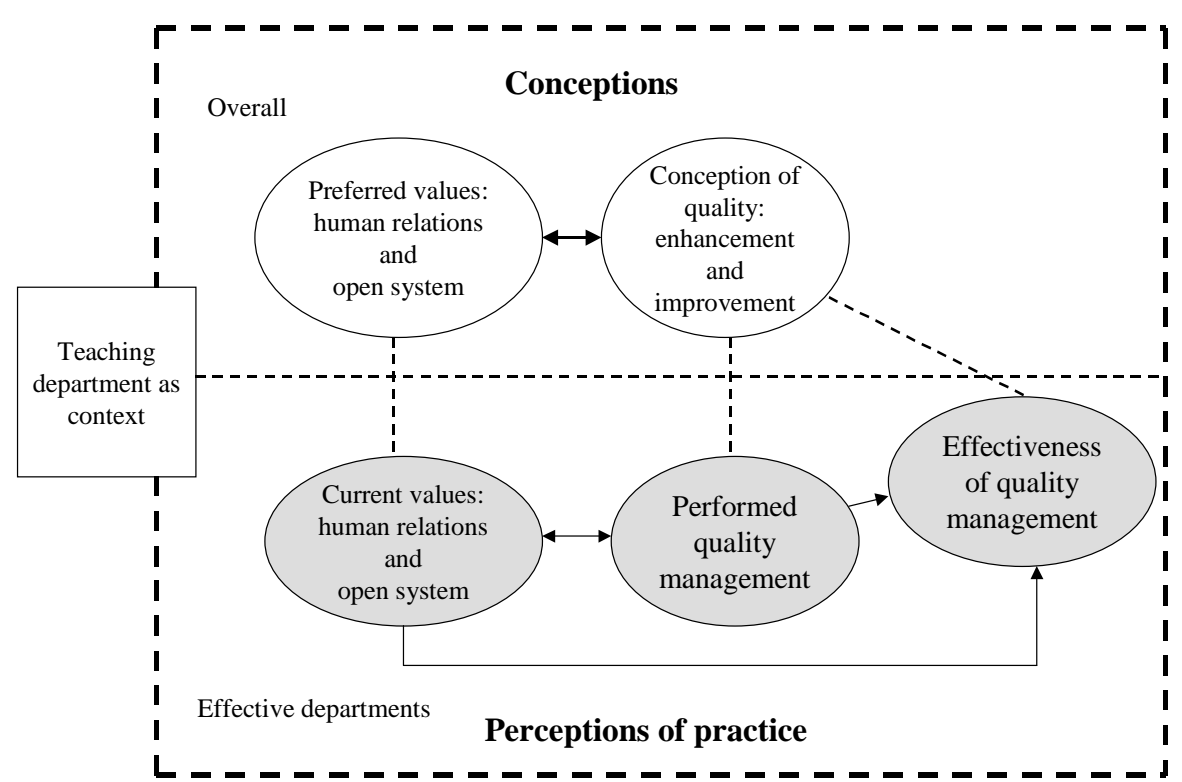

- Contextual influences for all departments

Observed relationships between departments

Figure 2. Empirical framework: conceptions and perceptions, environmental influences and observed relationships

\section{Conclusions and discussion}

In the literature some authors argue that quality management has positive effects (Brennan and Shah 2000; Westerheijden et al. 2007; Stensaker 2006). Other authors focus more on its negative effects (Watty 2002; Milliken and Colohan 2004; Cartwright 2007). In broad terms the findings of this qualitative study support and explain the results of the earlier quantitative research among teaching staff. It demonstrates that quality management, when systematically put into practice, is perceived as effective, as contributing to improvement and innovation of curricula, as enhancing better learning, good communication, active involvement of students and the external working field and as furthering compliance with external standards.

Secondly it can be concluded that senior staff of departments with an effective and a less effective quality management hold similar conceptions of quality of education and prefer the same organisational values. Within almost all departments the conceptions of quality are focused on continuous enhancement and improvement of education and much less on compliance to standards and accountability. Standards may provide direction but their interpretation by teaching staff is decisive. Senior staff of the various departments also share a clear preference for the flexibility- 
oriented organisational values of the human relations model and, albeit to a lesser degree, for the values of the open system model.

Thirdly, it can be concluded that the differences between the teaching departments relate to daily practice. In the case of the more effective departments quality management is perceived as being systematically implemented. Here quality management is characterised by clear quality objectives, the commitment of teaching staff, sufficient reflection upon evaluations, effective formal and informal communication, discussions about differences of opinion, taking decisions on improvements and monitoring them and a closed pdca cycle. In other words, quality management is a part of the day-to-day work of teaching staff and everyone is engaged. Additionally, within these departments senior staff think that the preferred organisational values are actually being put into practice. Teaching staff collaborate, there is a good collegiate atmosphere and a good relationship with students. Teaching staff and fellow workers are perceived as being open to criticism and feeling not threatened by it. Furthermore, they are perceived as having an outward vision and a willingness to change and innovate. The perceptions of senior staff of departments with a less effective quality management are totally different. According to them in their departments quality management activities are implemented as well but not in a systematic way and they are not part of day-to-day practice. Here quality management is mostly just consigned to paper. There is little commitment and participation of teaching staff and responsibilities are pushed onto the quality portfolio holder. In these departments, there is a huge gap between the preferred and the current values.

The final conclusion is that, in the eyes of staff there is a clear relationship between the effectiveness of quality management on the one hand and the degree to which flexible organisational values and internal quality management are put into practice on the other hand. These empirical findings are in line with the claims of Harvey and Green (1993), Cameron and Quinn (1999) and Kezar and Eckel (2002): an organisational culture within which the human relations values and the open system values are made dominant in practice provides a good seedbed for quality. Such an organisational culture has to a large degree the character of a learning organisation (Sitkin et al. 1994; Lanarès 2008). Nevertheless, in practice all too often a gap is experienced between preferred and current values, between the espoused theory and the theory in practice (Argyris 1990; Brunsson 1989) due to which quality management hardly can be effective.

This research leads to the following practical recommendations. Firstly, it is important for management to join in with the ideas of the teaching staff and their preferred values (Cameron and Quinn 1999; Newton 2000; Cruickshank 2003; Harvey and Stensaker 2008; Lanarés 2008). Ideas about education and quality should not be imposed but discussions on these matters should be encouraged. Secondly, quality management within departments should be embedded in day-to-day work. 
It should not be too complicated and not involve too much paperwork. Much more important than introducing complex methods of quality management is a systematic application of simple methods of evaluation and improvement and of monitoring these improvements. Thirdly, it is important to realise that simply managing quality may be not enough. It is equally important to develop a culture of collegiality and open communication, external orientation and willingness to change within a department. Discussion and inter-collegiate assessment are important, whereby staff are open to criticism and do not see criticism primarily as a threat, but more as a manner of supporting each other's work. Actually, the management board may set an inspiring example by making themselves open to criticism. At the same time, ambition and vision are needed whereby not everything is tackled at the same time, but realistic choices should be made on the basis of this vision and the available workforce and resources.

This qualitative research focuses on the conceptions and perceptions of senior staff. This is both an advantage and a limitation of the research. The advantage is that it gives a clear understanding of staff's conceptions and perceptions of quality, quality management and organisational values. The limitation is that these conceptions and perceptions might only partly reflect reality. Nevertheless the perceptions of the directly involved parties may provide a useful and practicable supplement to the picture of quality management. This does not alter the fact that it is desirable to link the findings and conclusions of this research to findings based on more objective indicators.

\section{References}

Argyris, C. (1990). Overcoming organizational defenses. Facilitating organizational Learning. Boston, London, etc.: Allyn and Bacon.

Brennan, J. \& Shah, T. (2000). Quality assessment and institutional change: experiences from 14 countries'. Higher Education, 40(3), 331-349.

Brunsson, N. (1989). The organization of hypocrisy. Talk, decisions and actions in organizations. Chichester, New York (etc.): John Wiley \& Sons.

Cameron, K. S. \& Quinn, R. E. (1999). Diagnosing and changing organizational culture. Based on the competing values framework. Reading, MA [etc.]: Addison-Wesley.

Cartwright, M.J. (2007). The rhetoric and reality of 'quality' in higher education. An investigation into staff perceptions of quality in post-1992 universities. Quality Assurance in Education, 15(3), 287-301.

Cruickshank, M. (2003). Total quality management in the higher education sector: A literature review from an international and Australian perspective. TQM \& Business Excellence, 14(10), 1159-1167.

EUA, European University Association. (2006). Quality culture in European universities: A bottom-up approach, Report on the three rounds of the quality culture project 2002-2006. Brussels: EUA.

Flick, U. (1992). Triangulation revisited: Strategy of validation or alternative? Journal of the Theory of Social Behaviour, 22(2), 175-197.

Gibson, A. (1986). Inspecting education. In G. Moodie (Ed.), Standards and criteria in higher education (pp. 128-135). Milton Keynes: SRHE \& Open University Press. 
Harvey, L. \& Green, D. (1993). Defining quality. Assessment \& Evaluation In Higher Education, 18(1), 934.

Harvey, L. \& Stensaker, B. (2008). Quality culture: Understandings, boundaries and linkages. European Journal of Education, 43(4), 427-442.

Houston, D. (2008). Rethinking quality and improvement in higher education. Quality Assurance in Education, 16(1), 61-79.

Howard, G. (1998). Validating the competing values model as a representation of organizational cultures, International Journal of Organizational Analysis 6 (3), 231-250.

Kezar, A. \& Eckel, P. (2002). The effect of institutional culture on change strategies in higher education. Higher Education, 73(4), 435-460.

Kleijnen, J., Dolmans, D., Willems, J., Muijtjens, A. \& Van Hout, J. (2009). Organisational values in higher education, perceptions and preferences of staff. Quality in Higher Education 15(3), 233-249.

Kleijnen, J., Dolmans, D., Willems. J. \& Van Hout, J. (2011). Does internal quality management contribute to more control or to improvement of higher education? A survey on faculty's perceptions. Quality Assurance in Education, 19(2), 141-155.

Kuper, A., Lingard, L. \& Levinson, W. (2008). Qualitative Research. Critically appraising qualitative research. BMJ 2008;337: a1035.

Lanarès, J. (2008). Developing a quality culture. In E. Froment, J. Purser, \& L. Wilson (Eds.), EUA Bologna handbook (C 2.101, pp. 1-27). Berlin: Raabe Verlag.

Lingard, L., Albert, M. \& Levinson, W. (2008). Qualitative research. Grounded theory, mixed methods, and action research. $B M J$ 2008; 337: a567.

Milliken, J. \& Colohan, G. (2004). Quality or control? Management in higher education. Journal on Higher Education Policy and Management, 26(3), 381-391.

Newton, J. (2000). Feeding the beast or improving quality?: Academics' perceptions of quality assurance and quality monitoring. Quality in Higher Education 6,(2), 153-163.

Patterson, M.G., West, M.A., Shackleton, V.J., Dawson, J.F., Lawthom, R., Maitlis, S., Robinson, D.L. \& Wallace, A.M. (2005). Validating the organizational climate measure: Links to managerial practices, productivity and innovation. Journal of Organizational Behavior 26(4), 379-408.

Pope, C. \& Mays, N. (2009). Critical reflections on the rise of qualitative research. BMJ 2009; 339: b3425.

Quinn, R. E., Faerman, S. R., Thompson, M. P., McGrath, M. R., \& St. Clair, L. S. (2007). Becoming a master manager: A competing values approach (4th ed.). New York [etc.]: Wiley.

Sitkin, S.B., Sutcliffe, K.M. \& Schroeder, R.G. (1994). Distinguishing control from learning in Total Quality Management: A contingency perspective', Academy of Management review, 18(3), 537-564.

Stensaker, B. (2006). Impact of quality processes, in EUA, Embedding quality culture in higher education. A selection of papers from the $1^{\text {st }}$ European Forum for Quality Assurance, 23-25 November 2006 in München, Germany (pp. 59-62). Brussels, Belgium: EUA.

Watty, K. (2002). Engaging grassroots academics in quality conversations and quality initiatives: opportunities lost?" Paper presented at Transforming Quality: Seventh quality in higher education international seminar, October 31 - November 1, in Melbourne, Australia. Available at: http://www.qualityresearchinternational.com/tq/papers/wattyoutline.doc.doc (accessed 11 May 2011).

Westerheijden, D.F., Hulpiau, V. \& Waeytens, K. (2007). From design and implementation to impact of quality assurance: an overview of some studies into what impacts improvement, Tertiary Education and Management, 13(4), 295-316.

Yorke, M. (2000). Developing a quality culture in higher education. Tertiary Education and Management, 6, 19-36. 
CHAPTER 7

Conclusions and general discussion 
CHAPTER 7 


\section{Internal quality management and its perceived effectiveness}

The studies in this thesis investigated teachers' perceptions of internal quality management and its effectiveness within teaching departments of universities of applied sciences (UAS) in the Netherlands. In the last part of the twentieth century higher education saw a massive rise in student numbers, causing an increase in public spending on higher education, followed by a major redirection of government policy from detailed national legislation to more autonomy for the institutions. Similar developments were witnessed in other parts of the Western world (Harvey \& Newton, 2007). These developments were accompanied by calls for increased public accountability resulting in the creation of a statutory system of external quality management. In response to this, the universities of applied sciences stepped up their efforts and investments in the development and implementation of internal quality management, which encompasses all activities and processes deliberately organised to design, assure, evaluate and improve the quality of teaching and learning. However, doubts have been raised as to the effectiveness of internal quality management. Some argue that it merely increases bureaucracy and hinders professionals in delivering quality education. Others, on the other hand, argue that it does actually promote continuous improvement. So far there is no substantive empirical evidence on this issue.

In this thesis, the effectiveness of internal quality management was studied by examining the perceptions of teaching staff, who after all are the professionals entrusted with the development and delivery of the educational programmes and the assessment of the students. As Van Hout (2006, p. 224) claims, teaching staff are not just stakeholders that might be involved in quality management: "Teaching staff, being the carriers of education, should be seen as the instigators and primary actors and pillars of quality management". Teachers' perceptions of the effectiveness of internal quality management depend on their views on quality. Do they see quality as compliance with minimal standards or as the striving for improvement and transformation? The effectiveness of quality management is also influenced by how it is organised within a department (Lewis \& Smith, 1994; Sallis, 2002, Harvey \& Stensaker, 2008). Is it only a matter of a few staff members with specific tasks, or does it involve all members of management and teaching staff? Moreover, the effectiveness of internal quality management is known to depend also on the organisational culture and values. Those implementing quality management should therefore take into consideration the prevailing values within the organisation (Zbaracki, 1998; Cameron \& Quinn, 1999; Newton, 2000, Kezar \& Eckel, 2002). Some organisations are characterised by flexibility-oriented values, others by control-oriented values. Flexibility-oriented values comprise human relations values, such as involvement, participation, trust, openness, cooperation and personal development, and open system values, such as external orientation, flexibility and willingness to 
change. The control oriented values are rational goal values, such as planning, goal setting and efficiency, and internal process values, such as information management, continuity and stability (Quinn et al. 1996). It is assumed that these values are related to the way quality management is executed (Cameron \& Quinn, 1999).

This thesis sought answers to five research questions. The first question relates to organisational values. Which values do teachers prefer within the context of their teaching department? To what extent do they perceive these values as indicative of the current situation in their department? Are there gaps between teachers' preferred values and the currently prevailing ones? Are these questions answered differently by teachers in different departments? (Chapters 3 and 6) The second research question concerns teachers' conceptions of quality. Do teaching staff see quality as compliance with basic requirements and accountability or as continuous enhancement and improvement of education (Chapters 4 and 6)? Questions three, four and five were addressed in Chapters 5 and 6 . The third question is aimed at gaining insight into teachers' perceptions of internal quality management as it is currently implemented within their departments. Does the department pay sufficient attention to the relevant aspects of quality? Are quality management activities sufficiently executed? Do the answers to these questions differ between departments? The fourth question focuses on teachers' perceptions of the effectiveness of internal quality management and on differences between departments in this respect. Finally, the fifth question asks about the relationships between the different variables that were studied. Does insight into organisational values and into teachers' conceptions and perceptions of quality and quality management shed light on the question why internal quality management is more effective in some departments than in others?

The research was conducted in a quantitative study among 266 teaching staff from 18 departments of universities of applied sciences in the Netherlands (Chapters 3-5) and in a qualitative study among 18 senior staff members from three departments with effective and three departments with less effective quality management (Chapter 6).

\section{Findings and conclusions}

The studies investigating the first question reveal that teaching staff have a strong preference for flexibility-oriented values over control-oriented values. This preference varies little across the departments. In most departments there are gaps between current and preferred values, with especially flexible values being put less into practice than is considered desirable by the teachers. However, the departments differ considerably in this regard. 
The results for the second research question show that teaching staff, irrespective of the department in which they are working, perceive quality more as enhancement and improvement than as compliance and accountability, with clear positive scores for the former and only slightly positive scores for the latter conception (4.14 versus 3.27 on a five-point scale). Nevertheless, the results reveal that these two conceptions of quality are moderately positively related (Pearson's $r=0.33$ ), in other words, they are by no means mutually exclusive and may even support each other.

The findings regarding the third question indicate that, overall, departments pay sufficient attention to the relevant quality aspects of education, but engage only to a moderate degree in organised quality management activities. Quality aspects are frequently evaluated but the evaluations do not always result in improvements. There are considerable differences between the departments. In some departments, quality management is characterised by clear quality objectives, by reflection and discussion on improvements and by decisions whose implementation is monitored. Here quality management is embedded within the day to day practice of teaching staff and management. It is not too complicated and everybody is involved. In other departments, on the other hand, quality management activities, if implemented, are not integrated into day to day practice, but mostly just consigned to paper. There is little commitment and responsibilities are pushed onto the quality portfolio specialist.

The answer to the fourth question, about the perceived effectiveness of quality management, revealed that, on the whole, teaching staff perceive more improvement effects of internal quality management, such as innovation of the curriculum and improvement of teaching and learning, than effects of control (3.55 versus 2.42 on a five point scale). The perceptions of improvement effects (perceived improvement) too varied significantly across the teaching departments.

The results for the fifth question, about the relationships between the different variables, show that the conception of quality as enhancement and improvement appears to be positively related to a preference for flexibility-oriented organisational values (Pearson's $r=0.39$ and 0.32 for the preferred human relations values and preferred open system values respectively, $p \leq 0.01$ ), whereas the conception of quality as compliance and accountability is associated with control-oriented values (Pearson's $r=0.21$ and 0.27 for the preferred rational goal values and preferred internal process values respectively, $\mathrm{p} \leq 0.01$ ). Furthermore, the results show a positive relationship between the perception of improvement effects of quality management (perceived improvement) and sufficient attention for the various quality aspects and quality management activities (Pearson's $r=0.51$ and $r=0.59$ for attention paid to quality aspects and quality management activities respectively, $\mathrm{p} \leq$ 0.01). Finally, the qualitative study shows a relationship between the actual performance and effectiveness of internal quality management and the degree to 
which the preferred organisational values, the flexibility-oriented human relations values and the open system values in particular, are put into practice in the departments. The relationships between the variables are depicted in Figure 1.

The answers to the fifth question give rise to two conclusions. Firstly, the preference for the flexible organisational values and the conception of quality as enhancement and improvement can hardly explain the variation of quality management activities and their perceived effectiveness over the departments, because in all researched departments teachers prefer the flexible organisational values and perceive quality as enhancement and improvement. The second conclusion is that practice offers a better explanation for the differences. Quality management is more effective in departments where, according to teaching staff, quality management is performed systematically, as part of day-to day practice, and flexible organisational values are actually put into practice. Within these departments, the flexibility-oriented organisational values and the characteristics of systematic quality management seem to be mutually supportive, a conclusion that finds support in the literature in which it is argued that quality management and organizational values should be aligned (Kezar \& Eckel, 2002, Cruickshank, 2003; Harvey \& Stensaker, 2008).

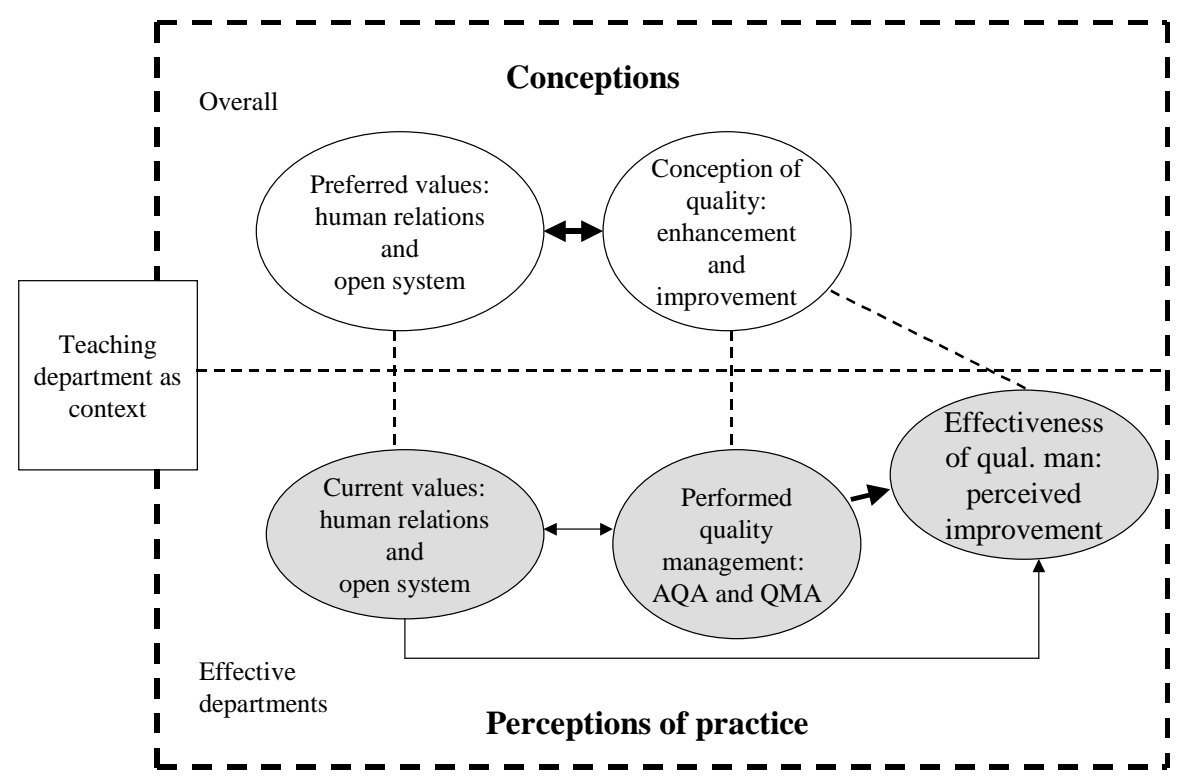

Notes: AQA: Attention paid to quality aspects; QMA: performed quality management activities

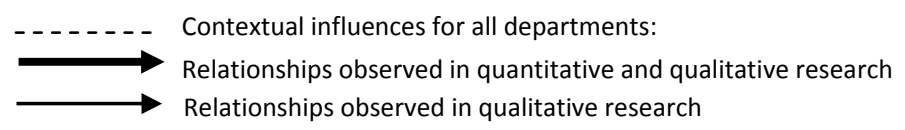

Figure 1. Empirical framework: observed relationships between conceptions and perceptions of practice 


\section{Discussion}

The findings and conclusions of the studies throw some light on three issues that are frequently discussed in the literature and seem to be inherent in internal quality management.

\section{Are 'compliance and accountability' and 'enhancement and improvement' mutually} exclusive opposites or do they support each another?

As a result of the introduction of external quality management systems, internal quality management frequently focuses on compliance with standards and accountability to management and external agencies. Some authors argue that compliance with standards can have quality enhancing effects (Huisman \& Currie 2004; Vanhoof \& Van Petegem 2007). It can broaden the scope of interest, stimulate internal quality assurance processes and legitimise the results of internal and external evaluations and the resulting quality claims of schools and individual teachers, which are also made transparent. Other authors have argued, on the other hand, that emphasis on standards may give rise to a tendency to "focus on the mechanistic implementation of recommendations" (Quinn \& Boughey 2009), especially when external quality management and accreditation are linked-up to the funding of the programme. This may result in a formal and legalistic approach to internal quality management in which exceeding standards or innovation are not the primary concerns. If that is the case, compliance and accountability are likely to be seen as managerialism and as bureaucratic inspection and intrusion (Newton 2002; Cartwright 2007). This may evoke evasive personal reactions from teachers, who are dissatisfied but accept the status quo and cooperate reluctantly or resort to window dressing and channel their energy and policies into personal interests and deceptive practices or even take refuge in withdrawal (Newton 2002, Watty 2002). According to these authors an exaggerated focus on compliance and accountability may go at the expense of enhancement and improvement.

In contrast to these misgivings and despite teachers and staff preferring the conception of enhancement and improvement as the key driver of quality, this thesis reveals that the two conceptions of compliance and accountability and enhancement and improvement are moderately positively correlated (Pearson's $r=$ 0.33) and should not be characterised as the opposite ends of a continuum. Provided the standards leave room for professional interpretation by teaching staff, they are frequently accepted and used as they are meant to be used, i.e. to guide the implementation of internal quality assurance activities (ENQA 2005, p. 13) rather than rejected as a dictate. In sum, compliance and accountability and enhancement and improvement are not mutually exclusive opposites but characteristics that can support each other. 


\section{A balance between values or an emphasis on flexible values?}

The second discussion bears on the issue of seeking a balance between the different organisational values or placing special emphasis on some values (Cameron \& Quinn, 1999; Berings, 2001; Lanarès, 2008). Each department should have strategies to cope with organisational ambivalences and competing values, and tensions between competing values should be regulated. Overemphasising certain values may have detrimental effects: human relations values may turn into extreme permissiveness and individualism and relentless discussion; open system values may lead to disastrous experimentation, ad hoc decisions, opportunism without principles and chaos; rational goal values may foster callous pressure for achievement and internal process values may end in stagnation, rigid behaviour and cynicism (Quinn et al. 1996).

The findings of this thesis demonstrate that teaching staff prefer the flexibilityoriented human relations and open system values over the control-oriented rational goal and internal process values. They also indicate that in the departments where the flexible organisational values are put into practice teachers perceive internal quality management as more effective. In the departments where internal quality management is perceived to be less effective, the flexible values are experienced to a much lesser degree in daily practice. Although control-oriented values are important and should not be neglected, flexible values seem to fit well with the autonomous professional roles of teaching staff and can create a flow that stimulates not only continuous improvement but also acceptance of the related control oriented values, such as planning, organisation and sticking to agreements. This suggests that in order to enhance the effectiveness of internal quality management, priority should be given to putting the flexibility-oriented values into practice without neglecting the control-oriented values.

\section{Raising quality by management or by culture and values?}

The third discussion regards the relationship between management and culture (Vettori, 2007). From a management perspective, internal quality management is characterised by clear quality objectives, a well-organised process with explicit responsibilities, established criteria and standards, tangible aims of evaluation, clearly defined key institutional data and systematic methods of data gathering and analysis (Harvey \& Newton 2004). As a consequence, quality management entails the control of management over internal and external developments and seems mainly based on control-oriented values, such as achieving the planned and established targets. Because of these characteristics and management's pursuit of a successful image, some critics observe a tendency to emphasise measurable aspects of quality and issues that are easy to envisage, irrespective of their relevance to real quality. As a result, the really big issues are in danger of being neglected. Organisations may 
(over)analyse whether things are being done well, but fail to assess whether it is the right things that are being done (Van der Zee, 1990; Koch, 2003; Cartwright, 2007).

From the studies reported within this thesis, however, we conclude that, overall, teaching staff perceive more positive than negative effects of internal quality management, despite significant variation across the teaching departments. Furthermore, the departments where quality management is perceived as being effective appear to perform quality management systematically and put flexibilityoriented values into practice. They are characterised by a culture of external orientation, openness to criticism, reflection, innovation and a willingness to collaborate. Flexible organisational values are perceived as a fertile feeding ground for quality and quality management. They foster an atmosphere of inspiring, mobilising, valuing and reflecting (INK, 2008). In sum, improvement of education depends not only on the systematic performance of quality management activities, but also on a flexible organisational culture in current practice.

\section{Implications for practice}

The findings of this study offer interesting perspectives for future efforts to enhance the quality of higher education. Firstly, quality management should link up neatly with the conceptions and preferences of teaching staff. Quality does not demand a rigid top-down approach, but above all a continuous cultural shift, "working within the framework of the existing culture, rather than going to war with it" (Cruickshank 2003, p. 1165). Because teaching staff generally cherish the conception of quality as enhancement and improvement and prefer flexibility-oriented organisational values, ideas about education and quality usually do not have to be imposed one-sidedly, but discussion about these matters should be encouraged. Management has a steering task but should also stimulate that the teachers themselves formulate and discuss the preferred transformations for their students and the improvements they would like to implement in their departments and programmes. Management should refrain from focusing primarily and exclusively on compliance with standards and criteria, but examine the degree to which management and teaching staff can coordinate their improvement objectives, shaping them in a systematic and consistent manner (Van Hout, 2006).

Secondly, quality management activities should be incorporated into the normal work of teaching staff and excessive paperwork is to be avoided. In other words, quality management should not be too complicated. Management should take care of the comprehensiveness of the quality management system, the complexity of problems and the elaboration of methods, but in the implementation and communication with staff they should focus on a limited number of selected aspects of quality that are in need of improvement. This can be a particularly effective strat- 
egy for teaching departments that are lagging behind in the field of quality management. Fostering real improvements, cautious monitoring of the improvement plans and ostensive rewarding of the improvements achieved are essential (Reichert, 2008).

Thirdly, the need for continuous improvement is also an incentive for departments to seek a realistic balance between the various competing and sometimes opposing values. Important features for assuring this continuity are rational goal and internal process values of decision making, efficiency, transparency and continuity, and related characteristics of the organisation, such as stable leadership and a transparent organisation. This does not alter the fact, however, that teaching departments first and foremost should work towards a culture of collegiality, open communication, external orientation and willingness to innovate. Discussion, intercollegiate evaluation and openness to criticism enable teaching staff and management to reinforce each other's efforts. These flexible human relations and open system values may well be the salient issues in quality management in present-day higher education.

\section{Methodological strengths and limitations}

Some strength and weaknesses of the studies within this thesis have to be considered. The first strength is that the studies are embedded in the literature and theories on quality, quality management and organisational values. Operationalisation of these rather complex concepts resulted in a written questionnaire that was used to measure the different concepts separately. The second strength is the use of both a quantitative (Chapters 3, 4 and 5) and a qualitative approach (Chapter 6) to investigate these concepts and their interrelationships, with the qualitative study adding depth to the understanding of the concepts. The third strength is the focus on the perspective of the teaching staff, a key stakeholder, given their daily professional involvement in education and working with students.

Some methodological and practical limitations are inherent in the studies. A first limitation is that the studies deal exclusively with perceptions. Although perceptions are important and a source of direct information, they may not fully reflect the complex reality of quality management and cultural practices within the departments. Moreover, the studies focus on the perceptions of teaching and senior staff to the neglect of the views of other stakeholders, such as students and the professional working field. The second limitation is one of sampling: the limited number of participating departments, causing a failure to achieve a balanced distribution over the various educational sectors, and the rather low number of teachers per department in the quantitative studies affect the generalisability of the conclusions. The scales used to measure conceptions of quality and perceptions of quality 
management and its effectiveness constitute a third limitation. They were developed on the basis of the quality management literature and validated by means of exploratory factor analysis, but not by means of confirmatory factor analysis. A last limitation is that this thesis, although it focused on disentangling relationships between the different variables in the different studies did not yet test the relationships between all the variables quantitatively in one model.

\section{Suggestions for further research}

An interesting avenue for further research would be to investigate internal quality management and its effects by studying documents and the views of other stakeholders. Such studies might focus on independent external stakeholders, such as members of external review committees, and on students and the professional working field. Secondly, in order to investigate the generalisability of the conclusions to other contexts, it is important to extend the validation of the scales that were developed in this thesis for measuring teachers' conceptions of quality and perceptions of internal quality management and its effectiveness. This validation could involve larger samples of departments across different educational sectors within universities of applied science as well as traditional universities. A third important area of further research would be the testing of causal relationships between all the different variables in one model. Finally, research could aim for increased insight into factors promoting an effective quality culture within teaching departments. What is the impact of different academic disciplines or of the structural aspects of an organisation (e.g. the diversity within a department)? Understanding these factors might contribute to the development of a flexible and balanced organisational culture and promote effective quality management within higher education.

\section{References}

Berings, D. (2001). Omgaan met concurrerende waarden als voorwaarde tot de ontwikkeling van integrale kwaliteitszorg in het hogescholenonderwijs in Vlaanderen, proefschrift [Coping with competing values as a prerequisite for developing integral quality management within university colleges in Flanders, dissertation]. Brussels, Belgium: EHSAL.

Cameron, K. S., \& Quinn, R. E. (1999). Diagnosing and changing organizational culture. Based on the competing values Framework. Reading, MA (etc.): Addison-Wesley.

Cartwright, M.J. (2007). The rhetoric and reality of 'quality' in higher education. An investigation into staff perceptions of quality in post-1992 universities. Quality Assurance in Education, 15(3), 287-301.

Cruickshank, M. (2003). Total quality management in the higher education sector: a literature review from an international and Australian perspective. TQM \& Business Excellence, 14(10), 1159-1167. 
ENQA, European Network for Quality Assurance in Higher Education. (2005). Standards and guidelines for quality assurance in the European higher education area. Brussels, Belgium: ENQA. Available at: http://www.enqa.eu/files/ENQA\%20Bergen\%20Report.pdf (accessed 20 October 2011).

Harvey, L., \& Newton, J. (2004). Transforming quality evaluation. Quality in Higher Education, 10(2), 149165.

Harvey, L., \& Newton, J. (2007). Transforming quality evaluation: moving on. In D.F. Westerheijden, B. Stensaker \& M.J. Rosa (Eds.), Quality assurance in higher education. Trends in regulation, translation and transformation (pp. 225-245). Dordrecht, The Netherlands: Springer.

Harvey, L., \& Stensaker, B. (2008). Quality culture: understandings, boundaries and linkages. European Journal of Education, 43(4), 427-442.

Huisman, J., \& Currie, J. (2004). Accountability in higher education: Bridge over troubled water? Higher Education, 48(4), 529-551.

INK. (2008). Introductie. Inhoud en toepassing van het INK-managementmodel [Introduction. Theory and practice of the INK management model]. Zaltbommel: INK.

Kezar, A., \& Eckel, P. D. (2002). The effect of institutional culture on change strategies in higher education. Universal principles or culturally responsive concepts? Higher Education, 73(4), 435-460.

Koch, J.V. (2003). TQM: why is its impact in higher education so small? The TQM Magazine, 15(5), 325333.

Lanarès, J. (2008). Developing a quality culture. In E. Froment, J. Purser \& L. Wilson (Eds.), EUA Bologna Handbook (C 2.101, pp. 1-27). Berlin: Raabe Verlag.

Lewis, R. G., \& Smith, D. H. (1994). Total quality in higher education. Delray Beach Florida: St. Lucie Press.

Newton, J. (2000). Feeding the beast or improving quality?: academics' perceptions of quality assurance and quality monitoring. Quality in Higher Education, 6 (2), 153-163.

Newton, J. (2002), Views from below: academics coping with quality. Quality in Higher Education, 8(1), 39-61.

Quinn, R.E., Faerman, S.R., Thompson, M.P., \& McGrath, M.R. (1996). Becoming a master manager: A competency framework ( $2^{\text {nd }}$ ed.). New York (etc.): Wiley.

Quinn, L., \& Boughey, C. (2009). A case study of an institutional audit. Quality in Higher Education, 15(2), 263-278.

Reichert, S. (2008). Looking back - looking forward: quality assurance and the bologna process. In EUA. Implementing and using quality assurance: strategy and practice (pp. 5-10). Brussels, Belgium: EUA.

Sallis, E. (2002). Total quality management in education ( $3^{\text {rd }}$ ed.). London: Kogan Page.

Van der Zee, H. (1990). Kwaliteitsverbetering en innovatiemanagement [Quality improvement and management of innovation]. Management en Organisatie, 44(3), 201-214.

Vanhoof, J., \& Van Petegem, P. (2007). Matching internal and external evaluation in an era of accountability and school development: Lessons from a Flemish perspective. Studies in Educational Evaluation, 22(2), 101-119.

Van Hout, H. (2006) Kwaliteitszorg in het HO: nog veel werk aan de winkel. [Quality assurance in higher education: much remains to be done]. In H. van Hout, G. ten Dam, M. Mirande, C. Terlouw \& J. Willems (Eds.), Vernieuwing in het hoger onderwijs. Onderwijskundig handboek (pp. 215-228) [Innovation in higher education. Education handbook (pp. 215-228)]. Assen, The Netherlands: Van Gorcum.

Vettori, O., Lueger, M., \& Knassmüller, M. (2007), Dealing with ambivalences - strategic options for nurturing a quality culture in teaching and learning. In EUA, Embedding quality culture in higher education. A selection of papers from the 1st European Forum for Quality Assurance, 22- 25 November 2006 (pp. 11-13). Brussels, Belgium: EUA.

Watty, K. (2002). Engaging grassroots academics in quality conversations and quality initiatives: opportunities lost? Outline. Paper presented at the International Conference on Transforming Quality: Seventh quality in higher education international seminar, 31 October - 1 November, Melbourne, Australia. Available at: http://www.qualityresearchinternational.com/tq/papers/wattyoutline.doc.doc (accessed 1 July 2010). 
CONCLUSIONS AND GENERAL DISCUSSION

Zbaracki, M. J. (1998). The rhetoric and reality of total quality management. Administrative Science Quarterly, 43(3): 602-636. 

Summary 
This thesis is aimed at investigating the effectiveness of internal quality management within teaching departments of universities of applied sciences in the Netherlands. Some argue that internal quality management does nothing but increase bureaucracy. Others argue that it effectively promotes continuous improvement. Besides, it is often contended that quality management endeavours frequently falter due to disregard for the conceptions, perceptions and preferred and shared organisational values of the people involved. This study intends to add to the, so far scant, empirical evidence for these issues. It researches internal quality management mainly from the perspective of teaching staff, who are seen as the professional pillars of education.

The first chapter describes the background of the study. The universities of applied sciences offer mainly educational programmes leading to a professional bachelor's degree. In the last part of the twentieth century they evolved from the more than 300 small institutions of higher vocational education, whose statutory position was enacted by the law on secondary education (WVO) in 1963. In the 1980s, both the traditional universities and the institutions of higher vocational education were facing a strong upsurge in the numbers of students, causing a vast increase in public expenditure on higher education. This provoked a shift in public policies and public control. Detailed regulation by the government was replaced by deregulation and autonomy. At the same time, detailed guidance by the Inspectorate of Education was replaced by guidance and accountability on main issues and a nation-wide external system of quality control. As the institutions were given progressively more responsibility for providing quality education, thinking in terms of quality became a part of their internal policies. Many institutions stepped up their quality endeavours and gradually combined their quality management activities into structured systems of internal quality management. Especially during the years between 1996 and 1999, the government and the universities of applied sciences increased expenditure to enhance the 'quality and doability' of programmes. Attention shifted from ex-post measurement of quality to the ex-ante processes of creating and assuring quality by documenting policies, structures, responsibilities and proceedings but also by promoting innovative educational projects and creating networks across organisational and institutional boundaries. These quality management activities were intended to be most tangible within the teaching departments. However, while internal quality management was perceived as being effective in some departments, in other departments the overriding perception was one of ineffectiveness. This thesis aims to understand (some of) the reasons for this.

The second chapter first explains the concepts and theories used. For empirical research, the concepts of quality, quality management and organisational values have to be considered separately, without disregarding their complex, dynamic and interrelated characteristics. The definitions of quality, the first concept to be explained, are manifold and dependent on the interests and perspectives of the 
stakeholders. Nevertheless there are two clearly prevailing conceptions of quality. The first one, compliance and accountability, is based on meeting minimal standards and thresholds that have to be proved, approved and accounted for. The second conception is related to enhancement and improvement of education. Quality management, the second concept to be explained, comprises all activities and processes that are deliberately carried out to design, assure, evaluate and improve the quality of teaching and learning. The third theoretical concept links up with the supposed importance of organisational values for the effectiveness of quality management. It describes the 'competing values framework' (Cameron and Quinn, 1999) based on three dimensions: an internal versus an external orientation, a focus on control versus flexibility, and organisational means and ends. The first two dimensions result in four models of organisational values. Two of these models are control oriented: the externally focused rational goal model and the internally focused internal process model. The other two models are flexibility oriented: the human relations model with an internal focus, and the open system model with an external focus. Following Cameron and Quinn (1999), a distinction is made between preferred values and values that are currently actually being applied in practice.

The second part of this chapter describes the five research questions and the research design. The first research question focuses on teachers' perceptions of organisational values: Which values do they prefer within the context of their teaching departments? Which values do they currently experience in practice? And are these questions answered differently in different departments? The second question relates to teachers' conceptions of quality, and the third question addresses teachers' perceptions of internal quality management. Do their departments pay sufficient attention to relevant aspects of quality? Do they execute sufficient quality management activities? Do the departments differ in relation to these questions? The fourth question inquires into teachers' perceptions of the effectiveness of internal quality management and the differences between the departments in this regard. The fifth question asks about the relationships between the different variables and whether an understanding of the organisational values and of the conceptions and perceptions of the teaching staff can be helpful in answering the question why quality management is more effective in some departments than in others.

Thereafter a research framework is presented that makes an explicit distinction between conceptions and practice. Two studies are presented: A quantitative study in which a written 100-item questionnaire was completed by 266 teachers of 18 teaching departments of various universities of applied sciences. The selection and operationalisation of the variables and the wording of the statements in the questionnaire are largely based on a review of the literature. The questions about the organisational culture were adopted, with the author's consent, from the Organisational Culture Assessment Instrument of Cameron and Quinn (1999). Hereafter, a qualitative study was conducted comprising semi-structured interviews with 18 
senior staff members of six departments. The aim was to delve deeper into the findings of the previous quantitative research and to substantiate and complement them (triangulation). The quantitative study is reported in Chapters 3 - 5 inclusive, the qualitative study in Chapter 6.

The third chapter focuses on Cameron and Quinn's four organisational values: the flexible human relations and open system values and the control-oriented rational goal and internal process values. Using the data of the questionnaire, the study investigates the preferences of faculty for these four organisational values (preferred values), the extent to which faculty perceive these values to be indicative of the current situation in their departments (current values), the gaps between current and preferred values and the differences between the departments with regard to these variables. The results show that, overall, the flexibility-oriented human relations and open system values are preferred over the control-oriented internal process and rational goal values. Overall, the teachers see only moderate evidence that the four organisational values are applied in daily practice, with the mean scores on the four current values being closely clustered near the neutral level. Furthermore, the preferred values receive higher scores than the current values, and the gaps between current and preferred values are wider for the flexible organisational values than for the control-oriented ones. Finally, there are small differences between the departments with regard to teachers' preferred values, as opposed to large interdepartmental differences in the current values and the gaps between current and preferred values. The gaps are smaller in some of the departments.

Chapter four reports on a study in which the questionnaire data are used to unravel the teachers' conceptions or notions of quality: do teaching staff conceive of quality as compliance and accountability or as enhancement and improvement of education and learning? The study then looks at teachers' preferred organisational values and also at the relationship between the conceptions of quality and the preferred organisational values. The results for the first research question show that faculty perceive quality first and foremost as enrichment of the possibilities and opportunities for their students, and as improvement of the department rather than as a compliance tool to satisfy standards and external accountability. Quality is primarily seen as a continuous, dynamic process aimed at ongoing improvement. Compliance and accountability may fulfil necessary functions for the organisation, but continuing improvement proves to be the key driving force for quality. With respect to the second research question, this study replicates the finding of the third chapter that the flexibility-oriented organisational values (human relations and open system) are preferred over the control-oriented values (rational goal and internal process). The outcomes for the third research question reveal a positive correlation between enhancement and improvement and flexibility-oriented values and also a positive, albeit somewhat weaker, correlation between compliance and ac- 
countability and control-oriented organisational values. Although these relationships are not very strong, they suggest that quality is a value-related concept.

The aim of the research presented in Chapter five is to contribute to the empirical evidence for the effectiveness of quality management. Again the questionnaire data from 266 teachers were used to explore teachers' perceptions with regard to the attention paid to relevant quality aspects of teaching and learning (inputs, processes and outputs), the quality management activities within the departments (design, evaluation and improvement of teaching and learning) and the question whether quality management activities contribute to control or to improvement of higher education. The study also examines differences between the departments and the relationships between the different variables. The first finding is that, overall, teachers are positive about the attention that is paid to the relevant quality aspects within their departments. The second finding is that, in general, teaching staff are neutral, neither satisfied nor dissatisfied, in their opinions on the degree to which quality management activities are actually taking place within their departments. These rather neutral scores indicate that quality management may not yet be an obvious activity in many departments. Thirdly, the results demonstrate that teaching staff are positive about the effects of quality management in terms of improvement and rather negative about its effects in terms of control. They indicate that quality management enhances both their work and the educational quality within their departments. These positive findings are striking, because both in the literature and the public media it is often argued that quality management is generally perceived as bureaucratic and its effects as predominantly negative. Almost equally important is the fourth finding showing substantial variation across departments in teachers' perceptions with regard to the amount of attention paid to quality aspects, quality management activities and improvement effects. Finally, the perceived improvement effect of quality management is found to be strongly and positively associated with the perceived amount of quality management activities conducted within the department and the amount of attention paid to quality aspects. This may indicate a strong quality culture in some departments and the absence of it in others. Some departments are doing quite well while others are performing rather poorly.

Chapter six presents the qualitative study aimed at substantiating and elucidating the findings of the quantitative studies (triangulation) and conducted in 2010 among eighteen senior staff members of six teaching departments included in the quantitative study. In that quantitative study three of these six departments had shown an effective and the other three a less effective quality management in the eyes of their teaching staff. The findings demonstrate that, if systematically put into practice, quality management is perceived as effective: it contributes to improvement and innovation of curricula and enhances learning. Furthermore, within all departments, irrespective of the effectiveness of quality management, senior staff 
agree with teaching staff on conceptions of quality and value preferences: they cherish the quality conception of enhancement and improvement of education rather than compliance and accountability and they prefer the flexible organisational values. Thirdly, the differences between the teaching departments are found to be clearly related to daily practice. In the case of the more effective departments, quality management is perceived as being systematically implemented. It is part of the day-to-day work of teaching staff and everyone is engaged. Additionally, senior staff of these departments indicate that the preferred organisational values are actually being put into practice. According to these senior staff members, teaching staff collaborate, are open to criticism and feel little threatened by it; they also have an outward vision and a willingness to change and innovate. Moreover, there is a good collegiate atmosphere and a good relationship with students. By contrast, the perceptions of senior staff of departments with less effective quality management are markedly different. Here quality management is mostly just consigned to paper. There is little commitment and participation of teaching staff, and responsibilities are pushed onto the quality portfolio holder.

Chapter seven discusses the findings and conclusions of the study, theoretical ambivalences, practical implications and methodological strengths and limitations of the research. The chapter ends with some suggestions for further research. The first conclusion is that the preference for the flexible organisational values and the conception of quality as enhancement and improvement can hardly explain the variation of quality management activities and their perceived effectiveness over the departments, because in all researched departments teachers prefer the flexible organisational values and perceive quality as enhancement and improvement. The second conclusion is that the practice offers a stronger explanation for the differences. In departments where, according to teaching staff, quality management is performed systematically and the flexible organisational values are put into practice, quality management is seen to be effective.

The discussion elaborates on three ambivalent issues of quality management. Firstly, it appears that the two conceptions of quality, compliance and accountability and enhancement and improvement, are not to be seen as mutually exclusive opposites but as mutually supportive complements, provided that the standards to be met leave room for professional interpretation. The second issue centres around the dilemma for teaching departments as to whether they should focus on flexible organisational values or on creating a balance between the flexible and the controloriented organisational values. It is suggested that in order to enhance the effectiveness of internal quality management, priority should be given to putting the flexibility-oriented values into practice. They create a flow that not only stimulates continuous improvement but also acceptance of the related process control. The third issue discussed is the relationship between quality management and organisational culture or values. Improvement of education appears not only to be depend- 
ent on the systematic performance of quality management but also on a flexible organisational culture in current practice.

The most notable implications for practice are closely related to these discussions. First of all, quality management and ideas about improvement of education should not be imposed, but linked up neatly with the prevailing conceptions among teaching staff of quality as enhancement and improvement and with their preferences for flexible organisational values. Management has a steering task but should also stimulate discussion with teaching staff. Secondly, quality management activities should be incorporated into normal work routines, should not involve too much paperwork and should not be too complicated. Management should take care of the comprehensiveness of the quality management system but in the immediate implementation they should focus on a limited number of selected aspects of quality that need improvement. Cautious monitoring of the improvement plans and ostensive rewarding of the improvements achieved are essential. Thirdly, although departments should strike a realistic balance between the various competing and sometimes opposing values, first of all they should work towards a culture of collegiality and open communication, external orientation and willingness to innovate. These flexible human relations and open system values may be the most salient issues in present-day higher education.

The chapter ends with a reflection on the methods used and suggestions for further research. Two of the strengths of this thesis are that the research is firmly based in theory and that it combines a quantitative and a qualitative method, thereby affording insights into the difficult and elusive concepts of quality, quality management and organisational values. Another strength is the perspective used: that of teaching staff as the pillars of education. A major limitation is that this thesis does not move beyond the perceptions of teachers and senior staff to include those of other stakeholders and sources of information. The small number of participating departments, with a rather low response per department, the limited validation of the scales and the fact that the relationships between the variables have not been tested in one model are three further limitations. Therefore, the first recommendation for further research is that quality management and its effects within departments should be addressed by examining documents and the perceptions of different groups of stakeholders. Secondly, it is suggested that the scales should be validated in studies among larger samples of departments and across different educational sectors within higher education. Thirdly, further research might also imply testing of the relationships between the variables within one model. Finally, research is recommended that is aimed at elucidating the structural and environmental factors influencing the realisation of values and the implementation of quality management within departments. 


\section{Reference}

Cameron, K. S., \& Quinn, R. E. (1999). Diagnosing and changing organizational culture. Based on the competing values Framework. Reading, MA [etc.]: Addison-Wesley. 
Samenvatting 
De effectiviteit van interne kwaliteitszorg in het hoger onderwijs staat geregeld ter discussie. Volgens sommigen leidt kwaliteitszorg alleen maar tot meer bureaucratie terwijl anderen juist vinden dat zij een bijdrage levert aan de voortdurende verbetering van het onderwijs. Daarnaast wordt vaak gesteld dat kwaliteitszorg geregeld mislukt doordat men bij de invoering ervan geen oog heeft voor de opvattingen en ervaringen (percepties) van de docenten die ermee te maken hebben, evenmin als voor de waarden die docenten voor hun organisatie wenselijk vinden en die zij samen koesteren. Er is nog maar weinig onderzoek gedaan op dit terrein en dit onderzoek wil een bijdrage leveren aan de empirische kennis. Dit proefschrift onderzoekt de effectiviteit van interne kwaliteitszorg binnen HBO-opleidingen aan Nederlandse hogescholen. Het is vooral gericht op het perspectief van de docenten omdat zij de professionele dragers van de opleiding zijn en de primaire actoren op het gebied van kwaliteitszorg.

Het eerste hoofdstuk beschrijft de achtergronden van de studie. De Nederlandse hogescholen zijn ontstaan in de laatste decennia van de twintigste eeuw en bieden vooral onderwijsprogramma's op bachelorniveau aan. Aanvankelijk waren er meer dan 300 kleine instellingen voor Hoger Beroeps Onderwijs (HBO). Hun wettelijke status werd geregeld in de Wet op het Voortgezet Onderwijs (WVO) van 1963. In de jaren '80 was er echter sprake van een sterke groei van het aantal studenten in het Wetenschappelijk Onderwijs (WO) en het HBO, en daardoor ook van een enorme stijging van de overheidsuitgaven voor hoger onderwijs. Dit leidde tot veranderingen in het overheidsbeleid, in de wettelijke kaders (WHBO, 1986; WHW, 1992) en in het publieke toezicht. Gedetailleerde regelgeving werd vervangen door deregulering en de autonomie van de instellingen werd gestimuleerd. Tegelijkertijd ging de Inspectie van het Onderwijs over van toezicht op details naar een systeem van verantwoording en toezicht op hoofdlijnen en een landelijk systeem van externe kwaliteitszorg. De instellingen werden steeds meer zelf verantwoordelijk voor het monitoren van de kwaliteit van hun onderwijs. Het aantal kwaliteitszorgactiviteiten nam toe en geleidelijk aan ontwikkelden veel instellingen samenhangende en gestructureerde systemen van interne kwaliteitszorg. Tussen 1996 en 1999 voerden de overheid en de universiteiten en hogescholen samen projecten uit die gericht waren op het versterken van de 'kwaliteit en studeerbaarheid' van de onderwijsprogramma's. De aandacht verschoof van kwaliteitsmeting achteraf naar ontwikkeling en borging van kwaliteit vooraf. Binnen de instellingen werden het beleid en de structuren, verantwoordelijkheden en processen formeel vastgesteld en gedocumenteerd maar er werden ook innovatieve onderwijsprojecten geïnitieerd en er kwamen netwerken van samenwerking tot stand die verder reikten dan de organisatorische grenzen binnen en tussen de instellingen. Het was de bedoeling dat deze kwaliteitszorgactiviteiten een positief effect zouden hebben op het onderwijs. Bij een aantal opleidingen vindt men deze interne kwaliteitszorg inderdaad effectief 
maar bij een aantal andere zeker nog niet. Het doel van dit proefschrift is enig licht te werpen op mogelijke verklaringen hiervoor.

Het tweede hoofdstuk begint met een overzicht van de gebruikte begrippen en theorieën. Om empirisch onderzoek mogelijk te maken moeten de begrippen 'kwaliteit', 'kwaliteitszorg' en 'organisatiewaarden' elk afzonderlijk worden besproken zonder hun complexiteit, dynamiek en onderlinge verwevenheid uit het oog te verliezen. Van het eerste begrip, 'kwaliteit', bestaan veel definities en die zijn telkens afhankelijk van de belangen en perspectieven van de betrokken groepering. Toch komen er steeds twee opvattingen naar voren. De eerste opvatting is compliance and accountability: kwaliteit is het voldoen aan minimale normen en standaarden. Dit moet worden aangetoond en vastgesteld en er moet verantwoording over worden afgelegd. De tweede opvatting is enhancement and improvement. Hier gaat het om het versterken en verbeteren van het onderwijs. Het tweede begrip, 'kwaliteitszorg', omvat alle activiteiten en processen die specifiek worden uitgevoerd om de kwaliteit van het onderwijs te ontwikkelen, te borgen, te evalueren en te verbeteren. Het derde begrip is 'organisatiewaarden': de waarden die men van belang vindt voor de organisatie. De veronderstelling is dat die waarden een grote invloed hebben op de effectiviteit van de interne kwaliteitszorg. Dit theoretische onderdeel van het hoofdstuk beschrijft ook het 'competing values framework', het model van concurrerende waarden van Cameron en Quinn (1999). Dit model is gebaseerd op drie dimensies. De eerste dimensie stelt interne oriëntatie van een organisatie tegenover externe oriëntatie. De tweede stelt beheersing (control) tegenover flexibiliteit en de derde stelt de nadruk op doelen tegenover de nadruk op middelen om die doelen te bereiken. Op basis van de eerste twee dimensies wordt een typologie van vier modellen van waardeoriëntaties gevormd. Twee modellen leggen de nadruk op beheersing: het rational goal model met een externe en het internal process model met een interne oriëntatie. De twee andere modellen leggen de nadruk op flexibiliteit: het intern gerichte human relations model en het extern gerichte open system model. De vier modellen beschrijven waarden die met elkaar concurreren en soms onderling tegenstrijdig zijn. In navolging van Cameron en Quinn (1999) maken wij een onderscheid tussen wenselijke waarden en waarden die werkelijk in praktijk worden gebracht.

Het tweede deel van het hoofdstuk beschrijft de onderzoeksvragen en het onderzoeksontwerp. Allereerst onderzoeken wij welke organisatiewaarden docenten wenselijk vinden binnen hun opleiding, welke waarden volgens hen ook echt in praktijk worden gebracht en of de opleidingen verschillen wat betreft deze gewenste of in praktijk gebrachte waarden. Ten tweede richten wij ons op de vraag welke opvattingen docenten hebben over 'kwaliteit van onderwijs'. Op de derde plaats onderzoeken wij welke percepties docenten hebben van de interne kwaliteitszorg binnen hun opleidingen: wordt er binnen hun opleidingen voldoende aandacht besteed aan de relevante aspecten van de onderwijskwaliteit, worden er voldoende 
kwaliteitszorgactiviteiten uitgevoerd en verschilt dit tussen de opleidingen? Ten vierde: wat vinden de docenten van de effectiviteit van de interne kwaliteitszorg binnen hun opleiding en ook hier onderzoeken wij de verschillen tussen de opleidingen. Ten vijfde bestuderen wij het verband tussen de verschillende variabelen en met name of inzicht in de organisatiewaarden en in de opvattingen en percepties van de docenten van de verschillende opleidingen een bijdrage levert aan de beantwoording van de vraag waarom kwaliteitszorg in sommige opleidingen effectiever is dan in andere.

Daarna wordt een onderzoeksmodel gepresenteerd dat een duidelijk onderscheid maakt tussen enerzijds de opvattingen van docenten en de waarden die zij wenselijk vinden en anderzijds de vraag hoe zij de dagelijkse praktijk ervaren. Er worden twee studies verricht. De eerste studie is een kwantitatief survey onder 266 docenten van 18 opleidingen van verschillende hogescholen. Daarbij wordt gebruik gemaakt van een schriftelijke vragenlijst. De selectie en operationalisatie van de variabelen en de formulering van de stellingen in de vragenlijst zijn grotendeels gebaseerd op literatuurstudie. De vragen over de organisatiecultuur zijn, met toestemming van de auteurs, overgenomen uit het 'Organisational Culture Assessment Instrument' van Cameron en Quinn (1999). De tweede studie is gebaseerd op kwalitatief onderzoek. Er wordt een semi-gestructureerd interview gehouden met in totaal 18 senior stafleden van zes opleidingen. Het doel daarvan is na te gaan of de bevindingen van het voorafgaande kwantitatieve onderzoek bevestigd kunnen worden, er dieper op in te gaan en ze aan te vullen (triangulatie). Het kwantitatieve onderzoek wordt beschreven in de hoofdstukken $3 \mathrm{t} / \mathrm{m} 5$; het kwalitatieve in hoofdstuk 6.

In het derde hoofdstuk worden de vier organisatiewaarden van Cameron en Quinn bestudeerd: de op flexibiliteit gerichte human relations en open system waarden en de op beheersing gerichte rational goal en internal process waarden. Met behulp van de schriftelijke enquête onder 266 docenten onderzoeken wij in hoeverre de docenten de vier organisatiewaarden wenselijk vinden (preferred values), in hoeverre zij vinden dat deze waarden in praktijk worden gebracht binnen de huidige situatie van hun opleiding (current values), hoe groot de kloof is tussen wens en praktijk en of er verschillen tussen opleidingen zijn ten aanzien van deze vragen. De resultaten van het onderzoek in dit hoofdstuk tonen allereerst aan dat de docenten in het algemeen een voorkeur hebben voor de op flexibiliteit gerichte human relations en open system waarden boven de op beheersing gerichte rational goal en internal process waarden. Een tweede bevinding is dat de docenten in het algemeen vinden dat de vier organisatiewaarden slechts matig in praktijk worden gebracht. De gemiddelde score van elk van de vier organisatiewaarden ligt dicht bij het neutrale niveau. Ten derde blijkt dat de wenselijkheid van alle waarden veel hoger ligt dan de perceptie van de mate waarin zij in praktijk worden gebracht en dat de kloof tussen wens en praktijk groter is bij de 'flexibele' waarden dan bij de 
waarden die gericht zijn op beheersing. Tenslotte geven de resultaten aan dat er, wat betreft de wenselijke waarden, slechts kleine verschillen zijn tussen de docenten van de verschillende opleidingen maar dat de opleidingen sterk verschillen in de mate waarin de waarden volgens de docenten in praktijk worden gebracht. En dit geldt ook voor de kloof tussen wens en praktijk. Bij sommige opleidingen is die kloof vrij klein en bij andere erg groot.

Hoofdstuk vier besteedt eerst aandacht aan de opvattingen van docenten over kwaliteit: hebben docenten een opvatting over kwaliteit als het voldoen aan standaarden en het afleggen van verantwoording of als het versterken en verbeteren van het onderwijs? Vervolgens onderzoekt het de organisatiewaarden die zij wenselijk vinden en tenslotte het verband tussen de kwaliteitsopvattingen en de gewenste organisatiewaarden. Ook voor deze studie maakten wij gebruik van de schriftelijke enquête. De resultaten van de eerste vraag tonen aan dat docenten kwaliteit op de eerste plaats zien als een verrijking van de mogelijkheden en kansen van hun studenten en als verbetering van hun opleiding. Zij zien kwaliteit veel meer als een continu, dynamisch proces met als doel het onderwijs steeds maar weer te blijven verbeteren dan als een middel om aan standaarden te voldoen en extern verantwoording af te leggen. Het voldoen aan standaarden en het afleggen van verantwoording daarover vervullen volgens de docenten weliswaar belangrijke functies voor de organisatie: zij stimuleren de invoering van interne kwaliteitszorg, zorgen ervoor dat belangrijke kwaliteitsaspecten niet aan de aandacht ontsnappen en dragen bij aan transparantie. Echter, uiteindelijk is het continu verbeteren de belangrijkste drijfveer voor kwaliteit. De tweede vraag wordt beantwoord conform de bevindingen in hoofdstuk 3: docenten hebben in het algemeen een voorkeur voor de op flexibiliteit gerichte organisatiewaarden (human relations en open system) boven de op beheersing gerichte waarden (rational goal en internal process). De resultaten van de derde vraag laten een positieve correlatie zien tussen de opvatting van kwaliteit als het versterken en verbeteren van onderwijs en de voorkeur voor de 'flexibele' organisatiewaarden en ook, zij het in mindere mate, tussen de opvatting van kwaliteit als voldoen aan standaarden en verantwoording en de voorkeur voor op beheersing gerichte waarden. Ook al zijn deze verbanden niet heel erg sterk, zij laten toch zien dat kwaliteit een begrip is dat mede vanuit waarden inhoud krijgt.

Het doel van het vijfde hoofdstuk is empirische gegevens aan te dragen over de effectiviteit van de kwaliteitszorg. Met behulp van de enquête is onderzocht of de opleidingen voldoende aandacht besteden aan de relevante aspecten van het onderwijs, aan de inputfactoren, de onderwijsprocessen en de resultaten daarvan en of de opleidingen voldoende kwaliteitszorgactiviteiten uitvoeren (ontwikkeling en ontwerp van onderwijs, evaluaties en verbeteractiviteiten). Ook de perceptie van de effectiviteit wordt onderzocht: leiden de kwaliteitszorgactiviteiten tot meer beheersing of tot verbetering van het onderwijs? Bovendien onderzoekt dit hoofdstuk de 
verschillen tussen de opleidingen en de samenhang tussen de verschillende variabelen. De eerste bevinding is dat docenten in het algemeen positief zijn over de aandacht die hun opleiding besteedt aan de relevante kwaliteitsaspecten. Vervolgens blijkt dat de docenten vinden dat hun opleidingen de kwaliteitszorgactiviteiten slechts matig uitvoeren, niet voldoende en niet onvoldoende. Deze matige scores tonen aan dat systematische kwaliteitszorg binnen veel opleidingen nog geen vanzelfsprekende activiteit is. Op de derde plaats wordt aangetoond dat de docenten meer verbetereffecten van kwaliteitszorg zien dan effecten van beheersing en control. Docenten geven aan dat kwaliteitszorg een positieve invloed heeft op hun werk en op de kwaliteit van het onderwijs binnen hun opleiding. Deze positieve resultaten zijn verrassend omdat zowel in de literatuur als in de media vaak wordt beweerd dat kwaliteitszorg over het algemeen wordt gezien als een bureaucratisch proces met vooral negatieve effecten. De vierde bevinding is dat de opleidingen aanzienlijk van elkaar verschillen wat betreft de aandacht voor kwaliteitsaspecten, de uitvoering van kwaliteitszorg en de effectiviteit daarvan in de perceptie van de docenten. Tenslotte wordt aangetoond dat de perceptie van verbetereffecten sterk positief samenhangt met de uitvoering van kwaliteitszorg en met de aandacht die aan kwaliteitsaspecten wordt besteed.

Hoofdstuk zes beschrijft de kwalitatieve studie die werd opgezet om de bevindingen van het kwantitatieve onderzoek te onderbouwen en te verduidelijken (triangulatie). Het onderzoek werd in 2010 uitgevoerd onder in totaal 18 senior stafleden van zes opleidingen die bij het kwantitatieve onderzoek betrokken waren. Drie van deze opleidingen hadden in de ogen van hun docenten een effectieve en drie een minder effectieve kwaliteitszorg. De studie onderzoekt de overeenkomsten en de verschillen tussen de effectieve en de minder effectieve opleidingen. Allereerst wordt aangetoond dat kwaliteitszorg die systematisch wordt uitgevoerd ook effectief wordt gevonden: de respondenten vinden dat de interne kwaliteitszorg een bijdrage levert aan de verbetering en vernieuwing van de curricula en een beter leerproces bij studenten bevordert. Op de tweede plaats laat deze studie zien dat de senior stafleden, evenals de docenten in het kwantitatieve onderzoek, binnen alle opleidingen vergelijkbare opvattingen hebben over kwaliteit en een voorkeur hebben voor dezelfde waarden. Zij hebben de opvatting dat kwaliteit vooral gericht is op het versterken en verbeteren van het onderwijs meer dan op het voldoen aan standaarden en het afleggen van verantwoording en zij hebben een voorkeur voor de op flexibiliteit gerichte organisatiewaarden. Op de derde plaats wordt aangetoond dat de verschillen tussen de opleidingen samenhangen met de praktijk van het dagelijkse werk. Bij de opleidingen met een effectieve kwaliteitszorg is de kwaliteitszorg systematisch opgezet. $\mathrm{Zij}$ is een onderdeel van het dagelijkse werk van elke medewerker. ledereen levert er een bijdrage aan. Bovendien vinden de respondenten dat de gewenste organisatiewaarden ook daadwerkelijk in praktijk worden gebracht. Er is volgens hen sprake van echte samenwerking tussen docenten. De do- 
centen staan open voor onderlinge kritiek en die kritiek leidt er niet toe dat men zich onveilig voelt. De docenten hebben oog voor wat buiten de opleiding gebeurt en zij zijn bereid te veranderen en te vernieuwen. Er heerst een goede intercollegiale sfeer en er zijn goede contacten met de studenten. De ervaringen van de respondenten bij de minder effectieve opleidingen zijn duidelijk anders. Bij deze opleidingen is kwaliteitszorg vooral een papieren exercitie. De docenten voelen zich er matig bij betrokken en nemen er maar weinig aan deel. De taken en verantwoordelijkheden worden veelal afgeschoven op de medewerker kwaliteitszorg of de docent die kwaliteitszorg in zijn portefeuille heeft.

Het zevende hoofdstuk geeft een overzicht van de bevindingen en conclusies van hoofdstukken $3 \mathrm{t} / \mathrm{m} 6$, een discussie over de theoretische ambivalenties en praktische implicaties daarvan. Daarnaast beschrijft het enkele sterke en zwakke punten van het onderzoek en geeft het enkele suggesties voor verder onderzoek. De eerste conclusie is dat de variatie van kwaliteitszorg en de effectiviteit daarvan over de opleidingen nauwelijks kan worden verklaard vanuit de waarden die men wenselijk vindt en de opvatting over kwaliteit die men heeft. In alle opleidingen heeft men immers een voorkeur voor de op flexibiliteit gerichte organisatiewaarden en de opvatting over kwaliteit als het versterken en verbeteren van het onderwijs overheerst bij alle opleidingen. De tweede conclusie is dat de verschillen tussen de opleidingen voor een groot deel worden verklaard door de praktische uitvoering. In opleidingen waar docenten vinden dat kwaliteitszorg systematisch wordt uitgevoerd en de 'flexibele' organisatiewaarden werkelijk in praktijk worden gebracht, vinden zij ook dat de interne kwaliteitszorg positieve effecten heeft.

De discussie over de resultaten en conclusies gaat in op drie aspecten van kwaliteitszorg die een ambivalent karakter hebben. Allereerst blijkt dat de twee opvattingen van kwaliteit, 'het voldoen aan standaarden en het afleggen van verantwoording' en 'het versterken en verbeteren' van onderwijs, elkaar niet uitsluiten maar elkaar juist ondersteunen, mits de standaarden voldoende ruimte laten voor professionele invulling. Wat betreft de vraag of de nadruk moeten liggen op het in praktijk brengen van de 'flexibele' organisatiewaarden of op een balans tussen de op flexibiliteit en de op beheersing gerichte organisatiewaarden is de conclusie dat de op flexibiliteit gerichte waarden niet alleen leiden tot continue verbetering maar ook tot zorg voor de beheersing van dit proces en het realiseren van de op beheersing gerichte waarden. Tenslotte geeft de discussie aan dat de verbetering van het onderwijs niet alleen een zaak is van management en systematische kwaliteitszorg maar dat het in praktijk brengen van de op flexibiliteit gerichte organisatiewaarden juist een gunstig klimaat schept waarin kwaliteitszorg kan gedijen.

Voor de praktijk betekent dit onderzoek dat kwaliteitszorg en ideeën over verbetering moeten aansluiten bij de algemeen geldende opvatting van docenten dat kwaliteit vooral het versterken en verbeteren van het onderwijs is en bij hun algemene voorkeur voor de op flexibiliteit gerichte organisatiewaarden. Het manage- 
ment heeft de taak sturend op te treden maar het moet ook de discussie met de docenten aangaan en stimuleren. Op de tweede plaats moeten kwaliteitszorgactiviteiten een onderdeel zijn van het gewone dagelijkse werk. Zij mogen niet teveel papierwerk met zich meebrengen en zij moeten niet al te ingewikkeld zijn. Het management moet ervoor zorgen dat het kwaliteitszorgsysteem rekening houdt met alle relevante aspecten van het onderwijs. Bij de invoering en uitwerking echter moeten de docenten zich kunnen richten op een beperkt aantal zorgvuldig uitgekozen aspecten waarvan de kwaliteit verbeterd moet worden. Het zorgvuldig volgen van het proces van verbetering en het duidelijk tonen van waardering voor de bereikte resultaten zijn van het grootste belang. Op de derde plaats: hoewel opleidingen zorg moeten dragen voor een realistische balans tussen de verschillende concurrerende en soms tegenstrijdige organisatiewaarden, moeten zij toch vooral werken aan een cultuur van collegiale samenwerking en open communicatie, externe gerichtheid en bereidheid te veranderen en te vernieuwen. Deze op flexibiliteit gerichte human relations en open system waarden zouden wel eens de belangrijkste oriëntaties kunnen zijn in het huidige hoger onderwijs.

Een sterk punt van dit onderzoek is de stevige theoretische fundering en de aanvulling van het kwantitatieve onderzoek met de kwalitatieve interviews waardoor het mogelijk is een beter inzicht te krijgen in de moeilijk grijpbare begrippen kwaliteit, kwaliteitszorg en organisatiewaarden. Ook is het een sterk punt dat kwaliteitszorg vooral wordt bestudeerd vanuit het perspectief van de docenten die immers de pijlers vormen waarop het onderwijs is gebaseerd. Een belangrijke beperking is echter dat het onderzoek alleen deze percepties van de docenten en senior stafleden bestudeert en geen aandacht besteedt aan de perceptie van andere betrokkenen en aan andere informatiebronnen. Ook het kleine aantal deelnemende opleidingen, de vrij lage respons per opleiding, de beperkte validatie van de nieuw ontwikkelde schalen en het feit dat de relaties tussen de variabelen niet in één model zijn getest vormen beperkingen van het onderzoek. De eerste suggestie voor het uitvoeren van verder onderzoek naar de effectiviteit van interne kwaliteitszorg is daarom de documentatie van opleidingen te bestuderen en onderzoek te verrichten naar de percepties van andere betrokkenen dan de docenten. Een tweede suggestie is interne kwaliteitszorg te bestuderen bij een groter aantal opleidingen uit diverse sectoren en wetenschapsgebieden binnen $\mathrm{HBO}$ en WO om de gebruikte schalen op die manier verder te valideren. Op de derde plaats kan dit verdere onderzoek ook gericht zijn op het testen van de causale en andere verbanden tussen de variabelen binnen één model. Tenslotte is het wenselijk verder onderzoek te verrichten naar de structurele en omgevingsfactoren van opleidingen en hun invloed op de realisatie van de organisatiewaarden en de implementatie van interne kwaliteitszorg. 


\section{Literatuur}

Cameron, K. S., \& Quinn, R. E. (1999). Diagnosing and changing organizational culture. Based on the competing values Framework. Reading, MA [etc.]: Addison-Wesley. 

Dankwoord 
Dit proefschrift is het resultaat van zeven jaar studie en onderzoek, vijf jaar naast mijn werk en twee jaar na mijn vervroegde pensioen. Het is weliswaar bescheiden van formaat en ook bescheiden als ik het vergelijk met mijn oorspronkelijke ambities maar ik ben er toch trots op. Het is immers niet vanzelfsprekend dat je kunt doen wat je moet doen en al helemaal niet dat je kunt doen wat je wilt doen. De totstandkoming van dit proefschrift is voor het grootste deel te danken aan de gunsten van het Leven en aan de mensen die mij omringden. Zij boden de uitdaging en gaven mij de vreugde om te starten maar ook de kracht en het doorzettingsvermogen om vol te houden. Daar ben ik hen heel dankbaar voor.

Mijn begeleiders speelden in dit leerproces een grote rol. Met Hans van Hout, mijn eerste promotor, heb ik urenlang in Utrecht gediscussieerd over de rol van georganiseerde kwaliteitszorg en de probleemstelling van het onderzoek. Wat is het verschil met de spontane zorg voor kwaliteit die je bij bijna elke leraar aantreft? Welke factoren kun je onderzoeken en welke ga je daadwerkelijk onderzoeken? Hans heeft door zijn uitgebreide kennis van het hoger onderwijs en van de ontwikkeling van kwaliteitszorg een grote invloed gehad op de belangrijkste keuzen in het onderzoek. Aanvankelijk bood hij veel ruimte voor verkennende probeersels maar al snel werd zijn begeleiding strakker. Hij stimuleerde mij tot beperking van het onderzoeksinstrument en nadat de gegevens verzameld waren, eiste hij intensieve bestudering ervan. Als een dirigent lette hij op de uitwerking van de hoofdthema's en de onderlinge afstemming, op de impact van afzonderlijke frasen en het specifieke woord en op het verloop van het proces. Tegelijk wees hij mij erop dat ik het proces vooral zelf moest bewaken omdat het onderzoek mijn persoonlijke keus was en niet was ingebed in het onderzoeksprogramma van een lectoraat of vakgroep. Ik ben hem veel dank verschuldigd, niet in het minst omdat het grootste deel van zijn begeleiding plaatsvond na zijn emeritaat. Diana Dolmans was de laatste vijf jaar mijn tweede promotor en meest directe begeleider. Vanuit een helder inzicht in de grote lijn had zij een scherp oog voor de gedetailleerde uitwerking. Zij was vasthoudend in het wijzen op mijn onuitroeibare neiging om even een zijpad te bewandelen - in het $\mathrm{HBO}$ en in de kwaliteitszorg zijn er veel hoofdwegen en evenveel interessante zijpaden - maar zij stimuleerde mij ook nieuwe wegen te verkennen, wanneer ik die gevonden leek te hebben, of zij wees mij op een weg die ik zelf over het hoofd had gezien. Vaak attendeerde zij mij erop dat mijn bewering onvoldoende was onderbouwd of dat mijn opmerkingen weer 'een nieuwe doos zouden openen', terwijl wij eerst de doos van onze probleemstelling goed dienden in te ruimen. Groot verschil van mening hadden wij slechts zelden en dit betrof bijna steeds de interpretatie van de gevonden resultaten, waar ik meestal verder wilde gaan dan zij verantwoord achtte. Zij creëerde een sfeer van prettige samenwerking maar dat weerhield haar er niet van uiterst kritisch te zijn. Door haar begeleiding werd ik meer zelfkritisch en meer zelfbewust. De begeleiding door Jos Willems was vooral gericht op de praktijknabijheid van het onderzoek en het neerzetten van heldere betooglijnen. Ge- 
sprekken met hem hadden meestal een brainstormend karakter, zowel wanneer zij betrekking hadden op dit onderzoek als op het werk binnen de hogeschool - Jos was acht jaar lang mijn direct leidinggevende: oprecht in zijn woorden en toegewijd aan de hogeschool en aan ons, zijn medewerkers. Mijn dank aan deze bijzondere leraren en begeleiders is groot. Dat geldt ook voor Arno Muijtjens die methodologisch meedacht over de opzet van het eerste artikel dat wij publiceerden (hoofdstuk 3) maar die mij ook later van enkele leerzame adviezen voorzag.

Dit onderzoek had niet kunnen worden uitgevoerd zonder de bereidwilligheid van al die docenten die de vragenlijst hebben ingevuld. Sommigen vonden hem wel heel erg lang, anderen vonden hem erg volledig en inspirerend maar voor de meesten bleef het een hele opgave. Hetzelfde geldt voor de respondenten bij de mondelinge interviews. Ook van hen werd een behoorlijke hoeveelheid tijd gevraagd al konden zij meer van hun eigen inzichten laten zien dan de geënquêteerden. Van de zes opleidingen die oorspronkelijk voor deze interviews werden benaderd, verklaarden vijf zich al direct bereid deel te nemen. Hun reacties op de interviewverslagen gaven mij het dankbare gevoel dat deze een bijdrage leverden aan de interne discussie binnen hun opleidingen.

De rond 1990 opgeheven opleiding Diëtetitiek aan de HBO Wachtendonck was mijn eerste kennismaking met spontane kwaliteitszorg. Marij Lafleur was voor mij hét voorbeeld van een HBO-docent. Zij stelde hoge theoretische eisen aan studenten op het gebied van voedingsleer en slaagde erin deze te koppelen aan de voedingspraktijk en tegelijk aan respect voor studenten die zij liefdevol en zorgvuldig begeleidde. Bovendien bleef zij ook zelf steeds verder leren. Binnen deze opleiding zetten wij, in samenwerking met de andere diëtetiekopleidingen in het land, duidelijke stappen om de doelen van het onderwijs te formuleren en de inhoud en werkvormen van het programma daarop af te stemmen. Het enthousiasme van wijlen Jef van der Zandt en zijn onderwijskundige collega's en de kritische en actieve houding van collega's als Jenny van Houdt maakten grote indruk. Onze toenmalige adjunct, Wim Ortjens Sr. had tussen de democratiseringsgolf van het begin van de jaren zeventig en het begin van de externe kwaliteitszorg, eind jaren '80 - dus in een tijd dat democratisering niet meer en kwaliteitszorg nog niet in de mode was - een schrift klaarliggen waarin de studenten hun mening over de docenten en hun onderwijs konden geven en de docenten weerwoord konden bieden: het gaf aanleiding tot menige discussie maar vooral ook tot verbeteringen in het onderwijs.

Pas na de eerste fusies in 1986 kreeg ik in mijn werk te maken met bewust georganiseerde en systematische kwaliteitszorg. Aanvankelijk ging de aandacht uit naar de eisen die door de externe kwaliteitszorg werden gesteld maar die nog niet in duidelijke kaders waren vervat. Op hogeschoolniveau was ik verantwoordelijk voor de opzet en begeleiding van de diverse zelfevaluaties en ik heb in die tijd veel geleerd van intensieve gesprekken met Martin Eurlings, Leon Sluijsmans en hun collega's van de PABO, met Jean Geelen, Theo Bertholet, Bas Ziekenheiner en hun 
collega's van de HTO-opleidingen en met Frans Daemen, Hans Voncken, George Meijer en hun collega's van de HEAO. De gesprekken gingen aanvankelijk vooral over de kwaliteit van hun opleidingen en over gegevens om dat aan te tonen maar daarna toch steeds meer over de vraag hoe wij deze gegevens konden gebruiken om de kwaliteit van het onderwijs te verhogen. Wij startten in die tijd ook met het systematisch verzamelen van evaluatieve oordelen van studenten en docenten en soms van het werkveld. Door hun bijdrage aan de verwerking van deze gegevens hebben Vincent Crutzen en Saskia Gijselhart er al vroeg voor gezorgd dat de kwaliteitszorg binnen Hogeschool Zuyd een research-based karakter kon krijgen.

In de periode van 'Kwaliteit en Studeerbaarheid' (1996-1999) heb ik veel geleerd van het onderwijskundig inzicht van Frank Janssen, de aandacht voor de (elektronische) leeromgeving van Guido Dautzenberg en niet in het minst van de manier waarop Gerrit van Rooij Total Quality Management en het INK-managementmodel binnen de hogeschool introduceerde. Telkens wanneer ik meende een model of een procedure te hebben beschreven waar de hogeschool een aantal jaren mee vooruit zou kunnen, wees hij weer op de vraagtekens die er overbleven, op de tekorten van het model en op het belang van voortdurend blijven verbeteren. Veel dank ben ik ook verschuldigd aan mijn collega's van de 'audit- en controlgroep' van Hogeschool Zuyd, aan Sylvie Laumans die ons er steeds op attendeerde dat een zelfsturend team aan hoge eisen diende te voldoen, aan Frits Kamps, Jacques Spee, Frans Velraeds, Esther Foppen, Mathy Peters en mijn altijd goedgehumeurde en relativerende kamergenoot Frans Daemen. Voor hen was samenwerking, collegialiteit en reflectie op het eigen handelen dagelijkse praktijk. Frits was niet alleen onze coördinator maar vooral een bindende kracht en goede vriend en ik ben blij dat hij, samen met mijn dochter Petra, mijn paranimf wil zijn tijdens de promotieplechtigheid. De opleidingen namen de zorg voor kwaliteit door middel van documentatie en verantwoording bijzonder serieus en een aantal managers met onderwijskundig leiderschap was zich ervan bewust dat de kern van kwaliteit gelegen is in reflectie en verbetering. Vooral Peter Hilderink hield de collega's van zijn opleiding en ons van audit en control steeds weer voor dat elk overleg begint met de vragen: wat hadden wij afgesproken? Hebben wij dat uitgevoerd? En wat is het resultaat daarvan? En ook: hebben wij dat zo beknopt vastgelegd dat het ook echt gebruikt gaat worden?

Tijdens het werken aan dit onderzoek heb ik dankbaar gebruik gemaakt van de inspirerende besprekingen binnen het Platform HBO van de NNK (Nederlands Netwerk voor Kwaliteitsmanagement) onder leiding van voorzitter Ben van Schijndel, van de kritische opmerkingen van Ingrid Wijgh over de probleemstelling en opzet van het onderzoek en van Hub Vinkenburg over de verhouding tussen kwantitatief en kwalitatief onderzoek en de ontvankelijkheid van de onderzoeker voor de signalen van zijn respondent. Saskia Gijselhart en Marcel Starmans dank ik voor hun bijdrage aan de totstandkoming en verwerking van de vragenlijst. Heel veel dank ben ik verschuldigd aan Mereke Gorsira. Haar correctie van mijn gebrekkige Engels be- 
perkte zich niet tot de afzonderlijke zinnen maar leidde vaak tot hernieuwde formulering van alinea's, tot een meer compacte omschrijving van wat ik bedoelde te zeggen en steeds tot een betere leesbaarheid. Hoewel het onderzoek geheel in mijn eigen tijd gebeurde, was dit proefschrift nooit tot stand gekomen zonder het vertrouwen en de morele en financiële steun van het College van Bestuur van Hogeschool Zuyd, vooral van Jos Willems maar zijdelings ook van Marjan Dunnewijk en Karel van Rosmalen en van de Secretaris van het Bestuur, Bert Nelissen.

In deze monomane proefschriftjaren was Maril de warme en levendige dwarsstraat van mijn leven met veel bochten en onverwachte doorkijkjes. Door haar zie ik de dingen telkens weer vanuit een andere, meestal vrolijkere hoek. Zij bood mij ruimte maar maakte mij ook deelgenoot van haar culturele en multiculturele leven en haar grote vriendenkring en zij zorgde ervoor dat ik bij de gewone - vaak de meest belangrijke - dingen van het leven betrokken bleef. Ik heb ontzettend veel aan haar te danken; misschien weet ik niet eens hoeveel. En ik dank hen wier liefde mij zomaar geschonken wordt: mijn broers en zussen en hun partners - wij waren er altijd voor elkaar; mijn lieve vriend Ton, die mij leerde dat je het leven ook gewoon kunt genieten en die al meer dan tien jaar niet meer bij ons is; en natuurlijk ook Naguib; en vooral Petra en Pim, Pien, Mees en Teun; Jeroen en Monique, Isa en Max; Els en Pascal, Zef, Doris, Zus en Meis; Stan en Jaukje en Toon; en Haske. Mijn kinderen en kleinkinderen moeten maar van mij aannemen dat leren boeiend is, op elk niveau, op elk terrein en op elke leeftijd: om zelf in te vullen .... maar ook door te luisteren naar aanbevelingen en kritiek. 

Curriculum vitae 
Jan Kleijnen was born in Kerkrade (L.), the Netherlands on April $4^{\text {th }}, 1947$. In 1965 he completed his secondary education at Gymnasium St' Alberti in Zenderen (Ov.). He studied philosophy at the Philosophical Institute of the diocese of Roermond, Heerlen (1965-1966), after which he attended Nijmegen University, graduating in Sociology in 1971. After a short period as a scientific assistant at Nijmegen University (1972), he spent all of his professional life at Hogeschool Zuyd (Zuyd University of Applied Sciences) and its predecessors (1972-2009), starting as a social science teacher. He was secretary to a group of five education programmes in dietetics striving to align their teaching programmes in consultation with the Dutch Association of Dieticians (1979-1981). Thereafter he undertook a collaborative project of the Limburg institutes of higher vocational education and the University of Limburg (1981-1983). Between 1984 and 1986 he coordinated the programme 'well-being of the elderly' of the Department of Facility Management, HBO-Wachtendonck, one of the institutes that later merged with Zuyd University. From 1986 until 2001 he was a senior educational advisor to the Board of Governors of 'Hogeschool Heerlen' and thereafter of 'Hogeschool Limburg', and in this capacity he was involved in the design, development and implementation of their educational policies. Starting in 1990 , he became involved in many activities of internal and external quality management, and between 1996 and 1999 he was one of the two coordinating managers of the institute's 'quality and doability' projects (Kwaliteit en Studeerbaarheid'). From 2001 until 2009, he was an internal operational auditor and from 2004 he was advisor on applied research to the Board of Governors. In this capacity he coordinated Zuyd University's project aimed at building an internal quality assurance system for the 'lectoraten' (small research units within universities of applied sciences). Between 2001 and 2009, he conducted many internal audits of educational departments and some of the 'lectoraten'. After his retirement in September 2009, he concentrated on his PhD dissertation, on which he had been working in his free time since 2005, as an external PhD candidate of the School of Health Professions Education (SHE), FHML, Maastricht University.

Jan Kleijnen is married to Maril Donders. Together, they have five children and ten grandchildren. 


\section{SHE Dissertation Series}

In the SHE Dissertation Series dissertations are published of PhD candidates from the School of Health Professions Education (SHE) who defended their PhD thesis at Maastricht University. The most recent ones are listed below. For more information go to: www.maastrichtuniversity.nl/she.

Persoon, M.C. (19-01-2012) Learning in Urology; The influence of simulators and human factors.

Pawlikowska, T.R.B. (21-12-2011) Patient Enablement; A Living Dialogue.

Sok Ying Liaw, (14-12-2011) Rescuing A Patient In Deteriorating Situations (RAPIDS): A programmatic approach in developing and evaluating a simulation-based educational program.

Singaram, V.S. (7-12-2011) Exploring the Impact of Diversity Factors on ProblemBased Collaborative Learning.

Balslev, T. (24-11-2011) Learning to diagnose using patient video cases in paediatrics: Perceptive and cognitive processes.

Widyandana, D. (19-10-2011) Integrating Pre-clinical skills training in skills laboratory and primary health care centers to prepare medical students for their clerkships.

Durning, S.J. (09-09-2011) Exploring the Influence of Contextual Factors of the Clinical Encounter on Clinical Reasoning Success (Unraveling context specificity).

Govaerts, M.J.B. (08-09-2011) Climbing the Pyramid;Towards Understanding Performance Assessment.

Stalmeijer, R. E. (07-07-2011) Evaluating Clinical Teaching through Cognitive Apprenticeship.

Malling, B.V.G. (01-07-2011) Managing word-based postgraduate medical education in clinical departments.

Veldhuijzen, J.W. (17-06-2011) Challenging the patient-centred paradigm: designing feasible guidelines for doctor patient communication.

Van Blankenstein, F. (18-05-2011) Elaboration during problem-based, small group discussion: A new approach to study collaborative learning.

Van Mook, W. (13-05-2011) Teaching and assessment of professional behavior: Rhetoric and reality. 
De Leng, B. (8-12-2009). Wired for learning. How computers can support interaction in small group learning in higher education.

Maiorova, T. (29-05-2009). The role of gender in medical specialty choice and general practice preferences.

Bokken, L. (04-03-2009). Innovative use of simulated patients for educational purposes.

Wagenaar, A. (18-09-2008). Learning in internships. What and how students learn from experience.

Driessen, E. (25-06-2008). Educating the self-critical doctor. Using portfolio to stimulate and assess medical students' reflection.

Derkx, H. (18-06-2008). For your ears only. Quality of telephone triage at out-ofhours centres in the Netherlands.

Niessen, Th. (30-11-2007). Emerging epistemologies: making sense of teaching practice.

Budé, L. (05-10-2007). On the improvement of students' conceptual understanding in statistics education.

Niemantsverdriet, S. (26-07-2007). Learning from international internships: A reconstruction in the medical domain.

Marambe, K. (20-06-2007). Patterns of student learning in medical education - A Sri Lankan study in traditional curriculum.

Pleijers, A. (19-01-2007). Tutorial group discussion in problem-based learning.

Sargeant, J. (21-09-2006). Multi-source feedback for physician learning and change.

Dornan, T. (12-06-2006). Experience-based learning.

Wass, V. (12-05-2006). The assessment of clinical competence in high stakes examinations.

Prince, K. (21-04-2006). Problem-based learning as a preparation for professional practice. 